San Jose State University

SJSU ScholarWorks

Master's Theses

Master's Theses and Graduate Research

Summer 2019

\title{
Comparisons of Upper Tropospheric Ozone at a Coastal and Urban Site and the Impact of Local Surface Emissions
}

Chloe Anne Gore

San Jose State University

Follow this and additional works at: https://scholarworks.sjsu.edu/etd_theses

\section{Recommended Citation}

Gore, Chloe Anne, "Comparisons of Upper Tropospheric Ozone at a Coastal and Urban Site and the Impact of Local Surface Emissions" (2019). Master's Theses. 5031.

DOI: https://doi.org/10.31979/etd.xhx2-5ugv

https://scholarworks.sjsu.edu/etd_theses/5031

This Thesis is brought to you for free and open access by the Master's Theses and Graduate Research at SJSU ScholarWorks. It has been accepted for inclusion in Master's Theses by an authorized administrator of SJSU ScholarWorks. For more information, please contact scholarworks@sjsu.edu. 
COMPARISON OF UPPER TROPOSPHERIC OZONE AT A COASTAL AND URBAN SITE AND THE IMPACT OF LOCAL SURFACE EMISSIONS

\author{
A Thesis \\ Presented to \\ The Faculty of Meteorology and Climate Science \\ San José State University \\ In Partial Fulfillment \\ of the Requirements for the Degree \\ Master of Science
}

by

Chloe Gore

August 2019 
(C) 2019

Chloe Gore

ALL RIGHTS RESERVED 
The Designated Thesis Committee Approves the Thesis Titled

COMPARISON OF UPPER TROPOSPHERIC OZONE AT A COASTAL AND URBAN SITE AND THE IMPACT OF LOCAL SURFACE EMISSIONS

\author{
by \\ Chloe Gore \\ APPROVED FOR THE DEPARTMENT OF METEOROLOGY AND CLIMATE \\ SCIENCE
}

SAN JOSÉ STATE UNIVERSITY

May 2019

Sen Chiao, Ph.D. Department of Meteorology and Climate Science

Martin Leach, Ph.D. Department of Meteorology and Climate Science

Matthew Johnson, Ph.D. NASA Ames Research Center 


\section{ABSTRACT \\ COMPARISON OF UPPER TROPOSPHERIC OZONE AT A COASTAL AND URBAN SITE AND THE IMPACT OF LOCAL SURFACE EMISSIONS \\ by Chloe Gore}

This study quantified the impact of urban emission sources on the enhancement of ozone $\left(\mathrm{O}_{3}\right)$ in the troposphere using data from simultaneous ozonesonde launches at Half Moon Bay (HMB), CA and San Jose (SJ), CA on eleven dates in July and August 2018. The urban $\mathrm{O}_{3}$ enhancement in the $\mathrm{SJ}$ vertical profile was derived by subtracting out $\mathrm{HMB}$, which represents baseline $\mathrm{O}_{3}$, from the $\mathrm{SJ}$ profile. This enhancement was averaged into $1 \mathrm{~km}$ layers and statistically analyzed with surface emission concentration data from three locations in SJ, however this did not reveal any discernable trends between the surface and $\mathrm{O}_{3}$ profile. Within the planetary boundary layer (PBL), $\mathrm{SJ} \mathrm{O}_{3}$ was 20-30 ppb higher than HMB for all dates. Above the PBL, most enhancement profiles remained close to zero, indicating few differences aloft between HMB and SJ. The two sites also had strong CCs and a least squares regression for all vertical levels between SJ and HMB revealed a slope of 0.79 and intercept of 0.02 . The percent contribution of mixing layer (ML) $\mathrm{O}_{3}$ to tropospheric $\mathrm{O}_{3}$ and tropospheric $\mathrm{O}_{3}$ to total column $\mathrm{O}_{3}$ revealed similar results. The contribution of $\mathrm{ML} \mathrm{O}_{3}$ was low for all dates, between 2-6\%, whereas the tropospheric contribution was $11-18 \%$. These findings emphasize the importance of baseline $\mathrm{O}_{3}$ in regions with reduced vertical mixing; polluted urban air near the surface has minimal impacts on $\mathrm{O}_{3}$ concentrations above the PBL. 


\section{ACKNOWLEDGMENTS}

I would like to thank my advisor, Dr. Sen Chiao, for the opportunity to pursue my thesis research under his guidance and support. His knowledge and advice have been an invaluable resource and greatly helped strengthen my research skills. Additionally, I thank my committee members, Dr. Martin Leach and Dr. Matthew Johnson, for their support with my research and thesis. I would also like to thank the Bay Area Air Quality Management District (BAAQMD) for sharing their data that was used in this project, as well as Drs. William Vance and Jin Xu from the California Air Resources Board (CARB) and Dr. Saffet Tanrikulu from the BAAQMD. This research was also supported by the NASA MUREP \# NNX15AQ02A. Finally, I would like to thank my family and friends

for their continued encouragement and interest in my work throughout this process and my husband, Logan, for his unwavering support and willingness to move to California so I could pursue my degree. 


\section{TABLE OF CONTENTS}

List of Tables............................................................ vii

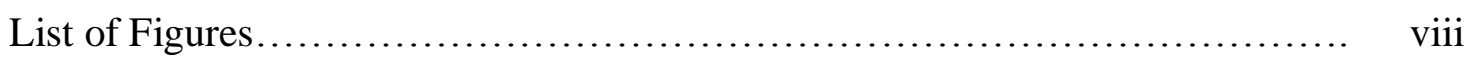

List of Abbreviations........................................................

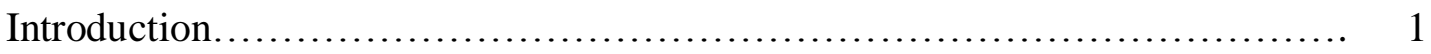

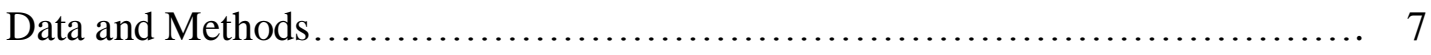

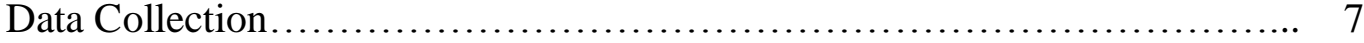

Ozone ............................................................. 7

Surface Station Data.................................................... 7

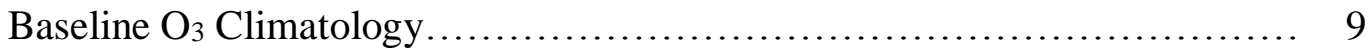

Urban Quantification................................................ 12

Correlations with Ozonesonde Enhancement Profile and Surface Station

Data.......................................................... 12

Estimating Mixing Layer Heights.................................. 14

HYSPLIT Analysis.............................................. 15

Mixing Layer, Tropospheric, and Total Column $\mathrm{O}_{3} \ldots \ldots \ldots \ldots \ldots \ldots \ldots \ldots . \quad 15$

Results and Discussion................................................. 16

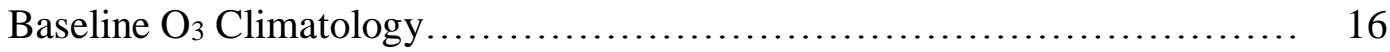

Urban Quantification.............................................. 18

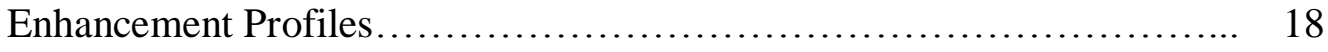

Stratospheric Intrusion Cases...................................... 27

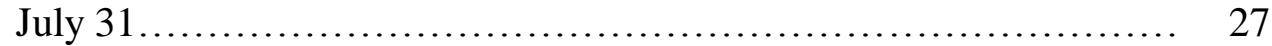

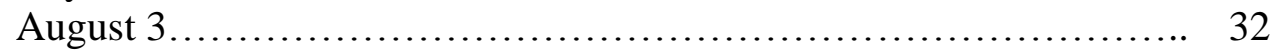

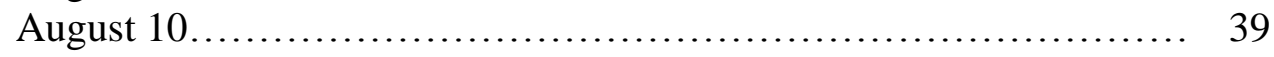

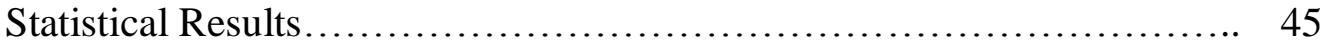

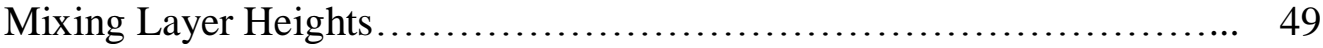

HYSPLIT ..................................................... 56

Mixing Layer, Tropospheric, and Total Column O3 Percent Contributions 61

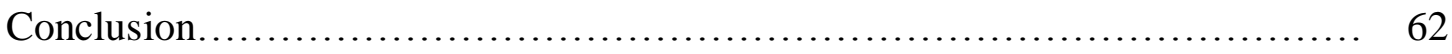

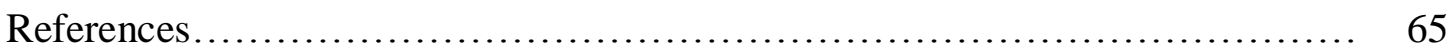




\section{LIST OF TABLES}

Table 1. Jackson Street station monitor specifications.................... 8

Table 2. Avenue station monitor specifications.......................... 9

Table 3. The roof of Duncan Hall station monitor specifications.............. 9

Table 4. Altitudes of compared total column $\mathrm{O}_{3}$ from 2016 to $2018 \ldots \ldots \ldots \ldots . . .12$

Table 5. Percentage of significant correlation coefficients observed for each species and location...............................................

Table 6. Percentage of significant correlation coefficients observed for each averaged enhancement profile layer........................... 48

Table 7. Percentage of significant correlation coefficients observed for each time before launch.............................................. 49

Table 8. Correlations between HMB and SJ profiles..................... 60 


\section{LIST OF FIGURES}

Figure 1. Location of surface stations measuring urban emissions......... 8

Figure 2. Location of all ozonesonde launches for the state of California. Trinidad Head is the longest, continuous dataset, with weekly measurements beginning in 1997. Duncan Hall is next to downtown San Jose, CA and is considered the urban site for the 2018 project.......................................... 10

Figure 3. Location of ozonesonde launch locations. Duncan Hall represents the San Jose, CA site, as it is located next to downtown...

Figure 4. Percent change of total column $\mathrm{O}_{3}$ from 2016 to 2018 for each week in July and the first three weeks in August. ...

Figure 5. Ozone profiles of HMB (red), SJ (blue) and the enhancement profile (green) from each launch.

Figure 6. $250 \mathrm{hPa}$ maps for July 31 (top), August 3 (middle), and August 10 (bottom). Images are provided by the University of Wyoming.

Figure 7. July 31 profiles from HMB (top) and SJ (bottom). Gray sections denote potential STE.

Figure 8. July 31 HYSPLIT back trajectory from HMB (top) and SJ (bottom) at STE altitudes

Figure 9. July 31 scatterplots of relative humidity and $\mathrm{O}_{3}$ for $\mathrm{HMB}$ (left) and SJ (right)....

Figure 10. July 31 RAQMS longitudinal cross section of $\mathrm{O}_{3}$ at $40^{\circ} \mathrm{N}$. Location of SJ is denoted by the yellow star.

Figure 11. August 3 profiles from HMB (top) and SJ (bottom). Gray sections denote potential STE.

Figure 12. August 3 HYSPLIT back trajectory from HMB (top) and SJ (bottom) at STE altitudes...

Figure 13. August 3 scatterplots of relative humidity and $\mathrm{O}_{3}$ for $\mathrm{HMB}$ (left) and SJ (right).... 
Figure 14. August 3 RAQMS longitudinal cross section of $\mathrm{O}_{3}$ at $40^{\circ} \mathrm{N}$. Location of SJ is denoted by the yellow star.

Figure 15. August 10 profiles from HMB (top) and SJ (bottom). Gray sections denote potential STE.

Figure 16. August 10 HYSPLIT back trajectory from HMB (top) and SJ (bottom) at STE altitudes.

Figure 17. August 10 scatterplots of relative humidity and $\mathrm{O}_{3}$ for $\mathrm{HMB}$ (left) and SJ (right)

Figure 18. August 10 RAQMS longitudinal cross section of $\mathrm{O}_{3}$ at $40^{\circ} \mathrm{N}$. Location of SJ is denoted by the yellow star...................

Figure 19. Mixing layer height $(\mathrm{m})$ estimations for SJ using the radiosonde observations of relative humidity $(\%)$ and potential temperature (K). At SJ, launches began at roughly $50 \mathrm{~m}$ above ground level. Mixing layer height is denoted by the black dashed line...

Figure 20. NOAA HYSPLIT backwards trajectory from SJ (Duncan Hall) for July 9. Similar trajectories were present for the other dates, so July 9 is shown to illustrate the overall flow pattern. The red line is $0 \mathrm{~km}$, blue line is $5 \mathrm{~km}$, and green line is $10 \mathrm{~km}$.

Figure 21. Scatterplot of San Jose $\mathrm{O}_{3}$ mixing ratios (ppmv) and Half Moon Bay $\mathrm{O}_{3}$ mixing ratios (ppmv) with a least squares regression line in red $\left(\mathrm{SJ}_{-} \mathrm{O}_{3}=0.79 * \mathrm{HMB}_{-} \mathrm{O}_{3}+0.02\right) \ldots \ldots \ldots \ldots \ldots \ldots \ldots \ldots \ldots \ldots \ldots \ldots$

Figure 22. Contribution of ML to tropospheric $\mathrm{O}_{3}$ and tropospheric to total

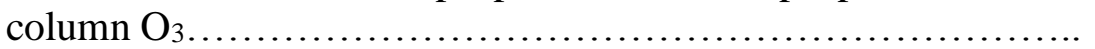




\section{LIST OF ABBREVIATIONS}

CC - Correlation Coefficient

$\mathrm{CH}_{4}$ - methane

$\mathrm{CO}$ - carbon monoxide

$\mathrm{CO}_{2}$ - carbon dioxide

HMB - Half Moon Bay

LGR GHG - Los Gatos Research Greenhouse Gas

$\mathrm{ML}$ - mixing layer

NCore - National Core

$\mathrm{NO}$ - nitrogen oxide

$\mathrm{NO}_{2}$ - nitrogen dioxide

$\mathrm{NO}_{\mathrm{x}}-$ oxides of nitrogen

$\mathrm{O}_{3}$ - ozone

PBL - planetary boundary layer

$\mathrm{PM}_{2.5}$ - particulates less than or equal to 2.5 microns in size

$\mathrm{ppb}$ - parts per billion

ppbv - parts per billion by volume

PST - Pacific Standard Time

ppm - parts per million

pptm - parts per ten million

RAQMS - Realtime Air Quality Modeling System

SLAMS - State or Local Air Monitoring Station

SJ - San Jose

STE - Stratospheric Intrusion

$\mathrm{ug} / \mathrm{m}^{3}$ - microgram per meter cubed

UTC - Universal Time Coordinated

VOC - volatile organic compounds 


\section{Introduction}

Ozone $\left(\mathrm{O}_{3}\right)$ is a secondary air pollutant formed primarily through the photochemical oxidation of carbon monoxide (CO) and volatile organic compounds (VOC) in the presence of nitrogen oxides ( $\mathrm{NO}_{\mathrm{x}}$ ) (Fiore et al. 2002; Jaffe et al. 2018; Wu et al. 2008). In the troposphere, $\mathrm{O}_{3}$ is harmful to human health and vegetation (Anenberg et al. 2010; Avnery et al. 2011; Avnery et al. 2011; Bell et al. 2006; Berman et al. 2012; Ellingsen et al. 2008; Ostro et al. 2012; Rai and Agrawai 2012; Smith et al. 2009; Turner et al. 2016). In 2015, the Environmental Protection Agency (EPA) lowered the National Ambient Air Quality Standard (NAAQS) for ozone from $75 \mathrm{ppb}$ to $70 \mathrm{ppb}$ (Environmental Protection Agency 2015). By definition, the NAAQS is met when the three-year average of the annual fourth-highest daily maximum 8-hour ozone concentration is less than or equal to 70 ppb (U.S. Environmental Protection Agency 1998). As a result, it is important to monitor $\mathrm{O}_{3}$ trends and design emission control strategies to reduce $\mathrm{O}_{3}$ concentrations and $\mathrm{O}_{3}$ precursor species.

Studies observing these tropospheric $\mathrm{O}_{3}$ trends have found a decrease in the overall variability and range (difference between days of low and high $\mathrm{O}_{3}$ mixing ratios) of surface $\mathrm{O}_{3}$ concentrations in numerous regions across the U.S. (Cooper et al. 2012; Lefohn et al. 2010; Simon et al. 2015). Additionally, Simon et al. (2015) observed increases in surface $\mathrm{O}_{3}$ concentrations on days with minimal ozone enhancements despite decreases in precursor emissions, indicating the complexity of reducing $\mathrm{O}_{3}$ through precursor emission controls alone. In the western U.S., observed $\mathrm{O}_{3}$ trends are increasing 
in the spring and summer months (Cooper et al. 2010; Jaffe et al. 2003; Jaffe and Ray 2007).

For regions in the western U.S., maintaining the NAAQS standard is a challenge due to the influence of baseline $\mathrm{O}_{3}$, which is defined by the Task Force on Hemispheric Transport of Air Pollution (HTAP) as an $\mathrm{O}_{3}$ concentration observed at a site uninfluenced by local anthropogenic activities (Cooper et al., 2011; Cooper et al., 2015; Task Force on Hemispheric Transport of Air Pollution 2010). Western coastal sites are largely impacted by synoptic transport of air masses across the Pacific. These air masses can transport high $\mathrm{O}_{3}$ concentrations from the Asian continent, increasing baseline $\mathrm{O}_{3}$ concentrations and creating challenges for improving local air quality (Cooper et al. 2010; Hudman et al. 2004; Lin et al. 2017; Oltmans et al. 2008; Ryoo et al. 2017). Additionally, Ryoo et al. 2017 examined a high $\mathrm{O}_{3}$ event off the central California coast on May 30 2012, and determined that Asian transport had a large impact on the air masses reaching the western U.S. Forward model trajectories also indicated that this transported high- $\mathrm{O}_{3}$ air could affect inland surface concentrations. The lifetime of tropospheric $\mathrm{O}_{3}$ is within the temporal scale for transport between continents (Parrish et al. 2014 and references therein). Parrish et al. (2014) noted that, aside from urban regions, this baseline $\mathrm{O}_{3}$ inflow is the controlling source of observed $\mathrm{O}_{3}$ concentrations.

Elevated $\mathrm{O}_{3}$ levels are also influenced by stratospheric intrusions (STE) (Langford et al. 2015; Langford et al. 2017; Langford et al. 2018; Lin et al. 2012). STEs typically result from tropopause folding, which entrains high $\mathrm{O}_{3}$ stratospheric air into the free troposphere (Langford et al. 2018). For example, Zhang et al. 2014 determined that 
lightning increases surface $\mathrm{O}_{3}$ mean levels and that STEs result in the highest $\mathrm{O}_{3}$ concentrations in the Intermountain West. They also examined the relationship between $\mathrm{O}_{3}$ levels and wildfires but did not reach a definitive conclusion. California anthropogenic emissions were determined to increase surface $\mathrm{O}_{3}$ concentrations downwind, as well. Lin et al. 2015 examined how climate variability impacts STEs and found that after strong La Nina winters, there is an increase in late spring STEs in the Western U.S. due to the northward shift of the polar jet stream into the Pacific Northwest.

The processes impacting $\mathrm{O}_{3}$ are spatially large scale, as demonstrated by Logan et al. 2012, who determined that a similar temporal variability of tropospheric $\mathrm{O}_{3}$ is present for the 500-1000 km scale. For example, Baylon et al. 2016 examined the impact of baseline $\mathrm{O}_{3}$ measured at Mount Bachelor Observatory $(\mathrm{MBO})$ on surface $\mathrm{O}_{3}$ at various sites in the Western U.S. and found that, under conducive meteorological conditions, the length of the surface station $\mathrm{O}_{3}$ correlation is $850 \mathrm{~km}$. Similarly, Wigder et al. 2013 assessed the transport of tropospheric $\mathrm{O}_{3}$ from $\mathrm{MBO}$ to Boise and marine boundary layer $\mathrm{O}_{3}$ from Cheeka Peak, WA to Enumclaw, WA and determined that, when the air mass influences Boise's MDA8 $\mathrm{O}_{3}$, MBO explained 40\% of Boise's MDA8 variation and Cheeka Peak explains $69 \%$ of Enumclaw MDA8 variations.

$\mathrm{O}_{3}$ concentrations are also influenced by various meteorological parameters. Solar radiation drives photochemical reactions of $\mathrm{O}_{3}$ precursor species (e.g., $\mathrm{NO}_{\mathrm{x}}$ ); therefore ample sunlight is favorable for high $\mathrm{O}_{3}$ production (Pudasainee et al. 2006). $\mathrm{O}_{3}$ exhibits a diurnal pattern, with high concentrations during the daytime and low concentrations at night, while the precursors (e.g. $\mathrm{NO}_{\mathrm{x}}$ ) have an opposite pattern (Tu et al. 2007). Seaman 
and Michelson 2000 identified synoptic conditions favorable for $\mathrm{O}_{3}$ production, including high temperatures, light winds, and minimal cloud cover. This is consistent with observations that indicate stable conditions are ideal for high $\mathrm{O}_{3}$ and poor air quality events. Knowledge of these characteristics is important for understanding $\mathrm{O}_{3}$ formation and the causes of non-attainment $\mathrm{O}_{3}$ episodes.

Mixing layer heights also determine the vertical mixing potential of surface pollutants. The planetary boundary layer (PBL) is the lowest layer of the atmosphere that is directly impacted by the surface. It has a fast response time to surface forcing, typically within an hour (Stull 1988). In the daytime, the unstable boundary layer, or mixing layer (ML), is formed, which is characterized by turbulent motion (Wang and Wang 2014). As a result, the volume of pollutant transport is controlled by the ML depth (Menut et al. 1999; Wang and Wang 2014; Zilitinkevich and Baklanov 2001). There are currently various methods to identify the ML height, such as finding the maximum gradient of potential temperature in a vertical profile, which indicates a transition zone from unstable air below to stable air above (Garrat 1994; Sediel et al. 2010; Wang and Wang 2014). Similarly, the maximum gradient of relative humidity, with less moisture above, can potentially signal the height of the ML (Ao et al. 2008; Sediel et al. 2010; Wang and Wang 2014).

In stable conditions, a lack of convection and turbulence can limit ML heights to less than $1 \mathrm{~km}$ (Garratt 1994). For example, Liu and Liang 2010 observed a stable boundary layer height of $86 \mathrm{~m}$ over Kansas, with average stable heights between $500 \mathrm{~m}-1 \mathrm{~km}$ over land. Daytime boundary layers over the U.S. from 1981 - 2005 typically remained below 
$1 \mathrm{~km}$ (Seidel 2012). Within central California, convective boundary layer (CBL) heights were highest in the spring months before decreasing to less than $1 \mathrm{~km}$ in July and August (Bianco et al. 2011). Additionally, the presence of haze has been observed to correlate with lower PBL heights (Quan et al. 2013) due to the reduction in incoming solar radiation reaching the surface and, thus, less surface heating and convective turbulence.

San Jose, CA is a Mediterranean climate, characterized by dry and warm conditions in summer and cooler, wet conditions in winter. It is a heavily populated, urban region located between the Santa Cruz mountains to the west and the Diablo mountains to the east. As a result, San Jose is in somewhat of a rain shadow, which limits the annual amount of precipitation compared to other regions in the Bay Area. San Jose experiences most precipitation in the winter months, with predominant synoptic high-pressure features (e.g. the Pacific High) leading to a lack of convection and stable conditions in the summer. As a result, ML heights are low in the summer months, despite warmer temperatures. For each launch at SJ, there were few to no clouds present and the potential temperature soundings were characterized by a low-level inversion.

$\mathrm{O}_{3}$ concentrations are also influenced by precursor emissions (Wigder et al. 2013). Increases in $\mathrm{NO}_{\mathrm{x}}$ and VOCs have been shown to lead to $\mathrm{O}_{3}$ increases (David and Nair 2011; Gorai et al. 2015; Grewe et al. 2012; John et al. 1998; Pusede and Cohen 2012; Wei et al. 2014). Carbon monoxide (CO) is a known precursor to $\mathrm{O}_{3}$; under photochemical conditions, $\mathrm{CO}$ and $\mathrm{O}_{3}$ have a positively correlated relationship (Chin et al. 1994; Fishman and Seiler 1983; Gilge et al. 2010; Macdonald et al. 2011). Methane $\left(\mathrm{CH}_{4}\right)$ can also act as a precursor to $\mathrm{O}_{3}$, however due to the long lifetime of $\mathrm{CH}_{4}$, these 
studies are primarily modeling analyses (Dentener et al. 2005; Fiore et al. 2002; Shindell et al. 2005; West et al. 2006).

Both indirect and direct $\mathrm{O}_{3}$ precursors are prevalent in urban regions as a result of the dense population, which leads to increased automobile activity, higher energy demands, etc. (Dodman 2011; Marcotullio et al. 2013). Urban locations in the western U.S. have additional challenges for reducing $\mathrm{O}_{3}$ concentrations due to the combination of $\mathrm{O}_{3}$ precursor emissions and high concentrations of baseline $\mathrm{O}_{3}$. For example, Cooper et al., 2012 observed decreases in rural $\mathrm{O}_{3}$ concentrations across the eastern United States in spring and summer months from 1990-2010, while the western sites had more significant increasing than decreasing trends. Additionally, Lin et al. 2015 observed springtime increasing $\mathrm{O}_{3}$ trends in western North America over the last decade and increasing background trends.

$\mathrm{O}_{3}$ studies have been conducted for northern and southern California (Cooper et al. 2011; Croes and Fujita 2003; Goldstein et al. 2004; Millet et al. 2004; Yates et al. 2013). To further supplement existing literature, the focal area of this study will be the Bay Area of central California, U.S. Central California is largely impacted by baseline $\mathrm{O}_{3}$ which, coupled with heavy urban pollution and seasonal wildfires, increases the frequency of non-attainment days. The quantified contribution of baseline $\mathrm{O}_{3}$ and $\mathrm{O}_{3}$ generated from urban precursor emissions is important to understand for future emission control planning. Therefore, the goal of this study is to quantify the impact of surface urban emissions on urban $\mathrm{O}_{3}$ enhancements and, subsequently, the inland transport of baseline 
$\mathrm{O}_{3}$, as well as determine how baseline $\mathrm{O}_{3}$ in central California has changed over the past three years.

\section{Data and Methods}

\subsection{Data collection}

\subsubsection{Ozone}

Droplet Measurement Technologies Electrochemical Concentration Cell (ECC) ozonesondes were utilized for obtaining the $\mathrm{O}_{3}$ vertical profiles for each experiment. These ozonesondes have an accuracy of $\pm 10 \%$ and precision of $\pm 6.5 \%$, making them a good estimate of $\mathrm{O}_{3}$ concentrations. Each ozonesonde was conditioned and prepped the day of flight with an ozonizer test unit. This unit has a high ozone source, a no/low ozone source, a 12 VDC pump, a 18 VDC power source and a power meter. As $\mathrm{O}_{3}$ laden air enters the cathode chamber, it reacts with the iodide in the cathode solution, resulting in the formation of an iodine molecule. This molecule is then converted back to iodide and two electrons of current are generated and flow through the circuit. Through this method, the current and flow rate can be used to calculate the $\mathrm{O}_{3}$ partial pressure (Johnson et al. 2002).

\subsubsection{Surface station data}

Hourly averaged surface concentration data were collected from three sites in San Jose (Figure 1) using instrumentation summarized in Tables 1-3 (Malone et al. 2013). San Jose typically experiences winds from NNW, so Jackson Street can provide upwind measurements for Duncan Hall at San Jose State University. Knox Avenue is downstream of this flow and is very close to a highway interchange; therefore, it will help 
capture $\mathrm{NO}_{\mathrm{x}}$ concentrations impacted by urban traffic emissions into and out of San Jose in addition to the upstream pollutants from downtown.

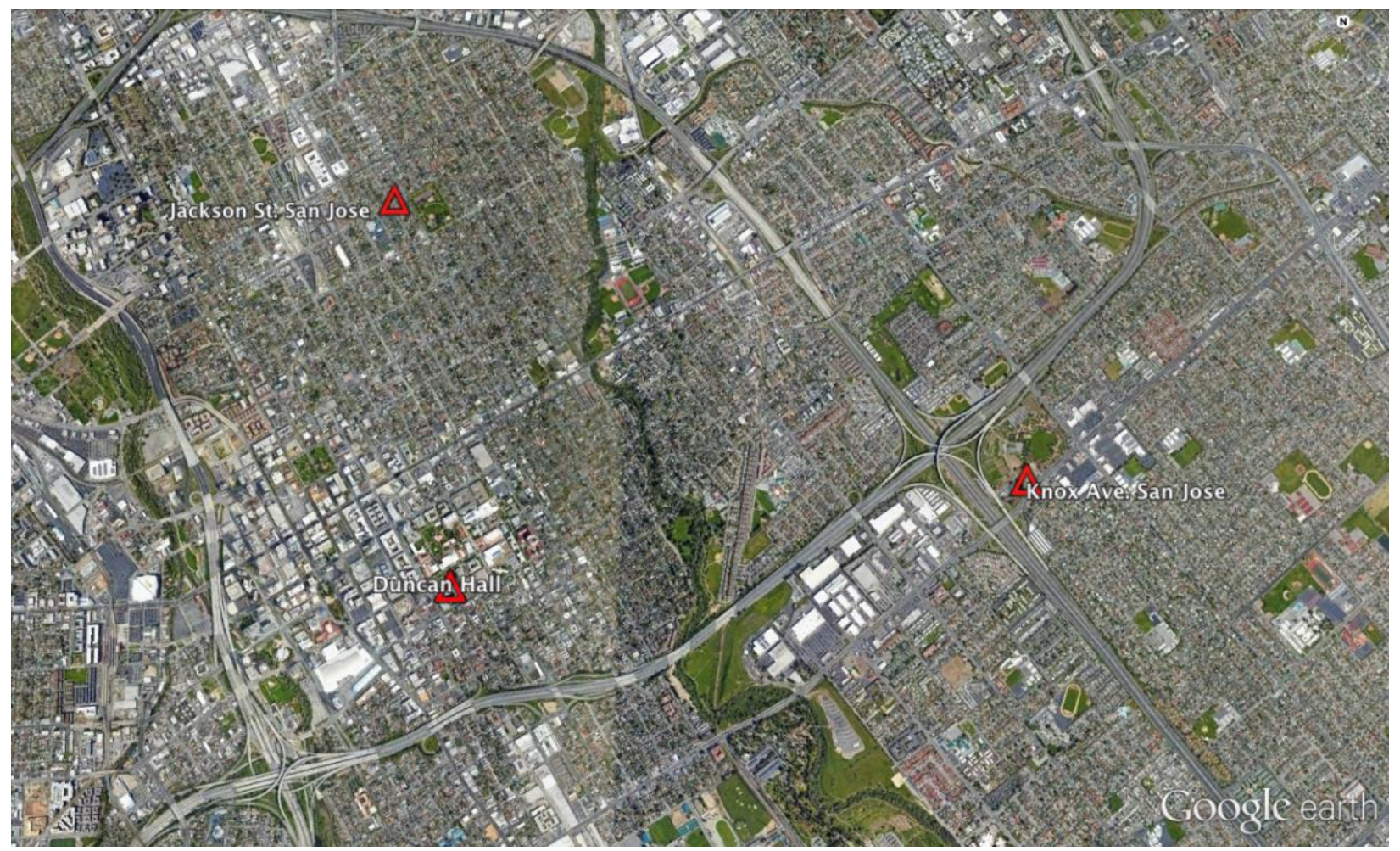

Figure 1. Location of surface stations measuring urban emissions.

Table 1. Jackson Street station monitor specifications.

\begin{tabular}{cccc}
\hline Pollutant & Monitor Type & $\begin{array}{c}\text { Manufacturer and } \\
\text { Model }\end{array}$ & Units \\
\hline $\mathrm{O}_{3}$ & SLAMS and NCore & TECO 49i & $\mathrm{ppb}$ \\
$\mathrm{CO}$ & SLAMS and NCore & TECO 48iTLE & $\mathrm{pptm}$ \\
$\mathrm{NO}$ and $\mathrm{NO}_{2}$ & SLAMS & TECO 42i & $\mathrm{ppb}$ \\
$\mathrm{SO}_{2}$ & SLAMS and NCore & TECO 43iTLE & $\mathrm{ppb}$ \\
$\mathrm{PM}_{2.5,3}$ & SLAMS and NCore & Met One FEM & $\mu \mathrm{g} / \mathrm{m}^{3} \_\mathrm{LC}$ \\
& & BAM 1020 & \\
\hline
\end{tabular}


Table 2. Knox Avenue station monitor specifications.

\begin{tabular}{ccc}
\hline Pollutant & Monitor Type & Units \\
\hline $\mathrm{CO}$ & SLAMS & $\mathrm{pptm}$ \\
$\mathrm{NO}$ and $\mathrm{NO}_{2}$ & SLAMS & $\mathrm{ppb}$ \\
$\mathrm{PM}_{2.5,3}$ & SLAMS & $\mu \mathrm{g} / \mathrm{m}^{3} \_\mathrm{LC}$ \\
\hline
\end{tabular}

Table 3. The roof of Duncan Hall station monitor specifications.

\begin{tabular}{ccc}
\hline Pollutant & Manufacturer and Model & Units \\
\hline $\mathrm{CO}$ & LGR GHG Analyzer & $\mathrm{ppm}$ \\
$\mathrm{CH}_{4}$ & LGR GHG Analyzer & $\mathrm{ppm}$ \\
$\mathrm{CO}_{2}$ & LGR GHG Analyzer & $\mathrm{ppm}$ \\
\hline
\end{tabular}

\subsection{Baseline $\mathrm{O}_{3}$ Climatology}

Beginning in May of 2016, a total of 110 near-daily ozonesonde launches occurred at Bodega Bay, CA (BBY) and Half Moon Bay, CA (HMB) (Figure 2) as a part of the California Baseline Ozone Transport Study (CABOTS). The goal of this study is to provide additional baseline $\mathrm{O}_{3}$ measurements for central California through the use of ozonesondes, aircraft data, and lidar measurements (Langford et al. 2019). This increase in baseline data will allow the state to form an effective State Implementation Plan (SIP) to prevent NAAQS nonattainment episodes, as well as aid in future planning of emission control strategies. 


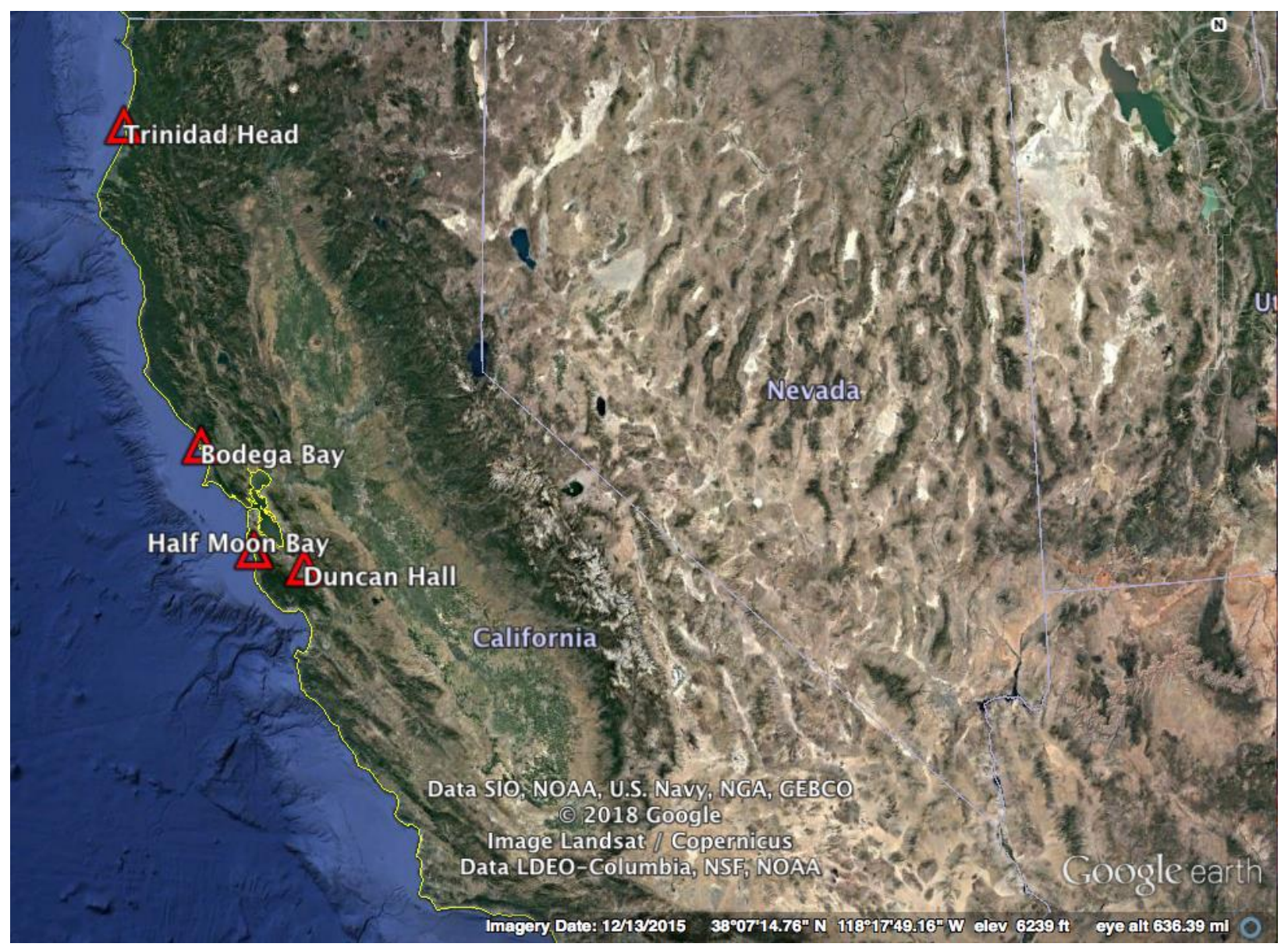

Figure 2. Location of all ozonesonde launches for the state of California. Trinidad Head is the longest, continuous dataset, with weekly measurements beginning in 1997. Duncan Hall is next to downtown San Jose, CA and is considered the urban site for the 2018 project.

This dataset was continued in 2017 with weekly measurements collected at HMB from June to December. These launches occurred on Thursdays at approximately 1400 PST (2100 UTC). In 2018, eleven ozonesondes were launched at HMB throughout July and August as a part of a separate field campaign that will be discussed in the following section.

Currently, Trinidad Head, CA (THD) is the only consistent ozonesonde launch site for the state of California, with weekly data available from 1997 to the present (Figure 2). As a result of the large latitudinal variation of the state and its climates, THD is not 
representative of the varying climates present in California. On a shorter temporal scale, it is important to examine baseline $\mathrm{O}_{3}$ trends in other regions of the state, so a short-term climatology of $\mathrm{HMB} / \mathrm{BBY}$ ozonesonde data was compiled to examine upper air $\mathrm{O}_{3}$ concentrations over central California.

HMB 2016 data are only available in late July through August, which limits the comparison to the 2018 data beginning early July. BBY and HMB are roughly $110 \mathrm{~km}$ apart, which is within horizontal synoptic boundaries. Additionally, a comparison of vertical profiles of $\mathrm{O}_{3}$, temperature, relative humidity, wind speed, and wind direction at the two sites reveals very similar results. Therefore, for the purposes of this study, BBY is assumed to be representative of HMB. Because of the site similarity, BBY 2016 will be used to compare to HMB 2018 on dates when HMB 2016 data are not available.

To establish a uniform frequency of measurements, data from BBY and HMB 2016 were weekly averaged, excluding weekends to remain consistent with the weekday measurements from HMB 2018. Additionally, dates with winds from the continent, as measured by the radiosonde, were filtered out to exclude any non-baseline $\mathrm{O}_{3}$ measurements. This eliminated 42 of the 85 dates from 2016. These weekly averages of total column $\mathrm{O}_{3}$ (DU) were then compared with the corresponding HMB 2018 data. To calculate the weekly average of ozonesonde data, the launches were grouped by week and interpolated so each vertical profile was the same size. The total column $\mathrm{O}_{3}$ was then averaged by week. Because the vertical profiles reached different altitudes for each launch, the corresponding average altitude for the total column measurement is different for each week. To maintain consistency, the total column $\mathrm{O}_{3}$ will be compared at the 
same altitude from 2016 to 2018 , as opposed to the maximum altitude in 2018 . The maximum height was selected for each 2016 week in order to capture as much of the column as possible and because these heights were all lower than the corresponding maximum 2018 heights. These altitudes are summarized in Table 4.

Table 4. Altitudes of compared total column $\mathrm{O}_{3}$ from 2016 to 2018.

\begin{tabular}{cc}
\hline Date & Total Column O3 Altitude (km) \\
\hline July 5 - July 8 & 13.8 \\
July 11 - July 15 & 17.2 \\
July 18 - July 22 & 14.4 \\
July 25 - July 29 & 18.0 \\
August 1 - August 5 & 17.0 \\
August 8 - August 12 & 17.8 \\
August 17 & 14.1 \\
\hline
\end{tabular}

\subsection{Urban Quantification}

2.3.1. Correlations with ozonesonde enhancement profile and surface station data

On eleven dates between July and August 2018, two ozonesondes were simultaneously launched from HMB and San Jose, CA (SJ) at approximately 1400 PST (2100 UTC) (Figure 3). This launch time was selected in order to capture peak $\mathrm{O}_{3}$ concentrations due to the photochemical production of $\mathrm{O}_{3}$ during the daytime. Each experiment lasted around 2 hours and reached an altitude of about $20 \mathrm{~km}$. To focus on tropospheric $\mathrm{O}_{3}$, only the lowest $15 \mathrm{~km}$ will be studied. Launch dates were selected based 
on ideal onshore wind conditions aloft (southwest to northwest winds) to ensure measurements of baseline $\mathrm{O}_{3}$ at $\mathrm{HMB}$ and to represent the inland transport of the HMB airmass into the $\mathrm{SJ}$ region. To quantify the enhancement of $\mathrm{O}_{3}$ in the urban profile in the absence of baseline $\mathrm{O}_{3}, \mathrm{HMB}$ was subtracted out of $\mathrm{SJ}$, creating what will be called the "enhancement profile" for each date. A statistical comparison between the two profiles on each date was also explored to verify that HMB can be assumed to represent baseline $\mathrm{O}_{3}$ for $\mathrm{SJ}$.

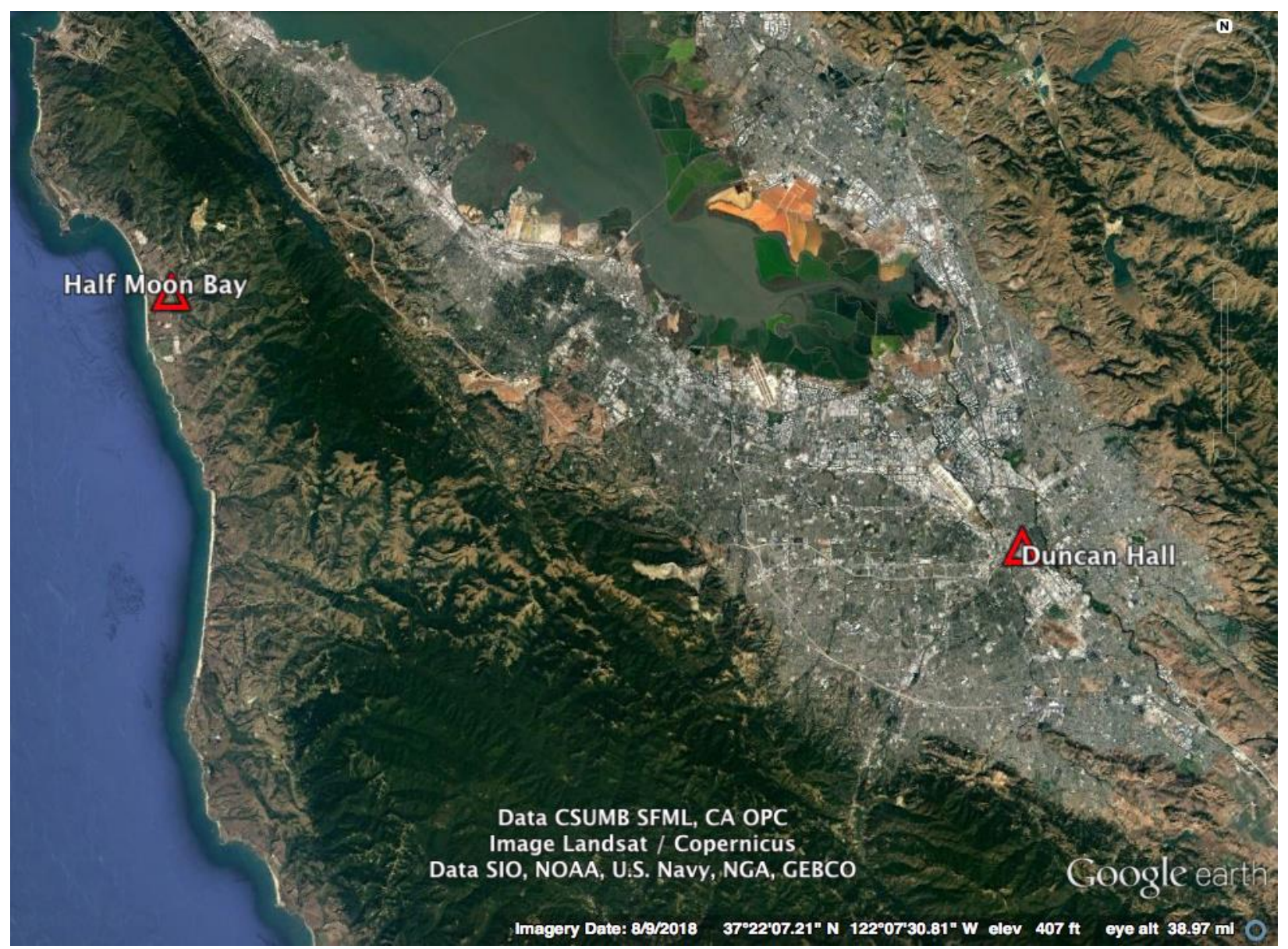

Figure 3. Location of ozonesonde launch locations. Duncan Hall represents the San Jose, CA site, as it is located next to downtown. 
To account for the different frequencies of measurements between the surface and the $\mathrm{O}_{3}$ profile, each enhancement profile was averaged into $1 \mathrm{~km}$ sections from the surface to $15 \mathrm{~km}$. Each species and location of surface data, beginning from 0000 PST (0700 UTC) up to 1300 PST (2000 UTC) to account for the variance in lag time from peak precursor emission concentrations to peak $\mathrm{O}_{3}$ formation, were then correlated using a Pearson correlation analysis with the averaged layers. The analysis was conducted using statistical functions from the SciPy Python library. This results in a species, location, hour before launch, and averaged layer mapped to a specific correlation coefficient (CC). Variables with CCs greater than 0.5 or less than -0.5 and a p-value less than or equal to 0.05 are considered significant and will be discussed (i.e. a 95\% confidence interval).

\subsubsection{Estimating mixing layer heights}

To confirm the validity of the statistical results, the mixing layer (ML) heights for each date over SJ were estimated using vertical profiles of relative humidity (\%) and potential temperature $(\mathrm{K})$ provided by the radiosonde. As discussed in the introduction, identifying the maximum gradients of relative humidity and potential temperature is an adequate method for estimating the top of the ML. The two variables were plotted together and locations where a visibly steep drop in relative humidity and an increase in potential temperature were denoted as the ML top. Because this is an estimate, the ML heights were also validated with the Weather Research and Forecasting (WRF) model. The North American Mesoscale Model (NAM) 6-hour reanalysis data were used for the model input and the Thompson physics scheme was applied as the physics parametrization. For each launch date, a 24-hour model run (0000 UTC on launch date - 
0000 UTC on the day after) was conducted for a $1 \mathrm{~km}$ by $1 \mathrm{~km}$ domain covering HMB and SJ.

\subsubsection{HYSPLIT analysis}

An additional analysis was completed using the NOAA Hybrid Single-Particle Lagrangian Integrated Trajectory model (HYSPLIT) model to determine the source of the airmass at $\mathrm{SJ}$ and if $\mathrm{HMB}$ is representative of the baseline $\mathrm{O}_{3}$ transported into the urban region. The archived Global Data Assimilation System (GDAS) $0.5^{\circ}$ meteorology file on the date of each launch was selected for the model input. A 24-hour backwards trajectory from SJ $\left(37^{\circ} 19^{\prime} 57.78^{\prime \prime} \mathrm{N}, 121^{\circ} 52^{\prime} 56.55^{\prime \prime} \mathrm{W}\right)$ beginning at $2100 \mathrm{UTC}$ on the launch date was run at $0.05,5$, and $10 \mathrm{~km}$ altitudes to capture the entire tropospheric column.

\subsubsection{Mixing layer, tropospheric, and total column $\mathrm{O}_{3}$}

Following the methods of David and Nair (2011), the ML, tropospheric, and total column $\mathrm{O}_{3}$ at $\mathrm{SJ}$ were compared using the ozonesonde and the MERRA-2 single-level diagnostics, instantaneous, 1 hour model $\left(0.5^{\circ} \times 0.625^{\circ}\right)$. The ozonesonde provides total column $\mathrm{O}_{3}$ measurements at each altitude level in Dobson Units (DU). Tropopause pressure and total column $\mathrm{O}_{3}$ for all vertical levels were obtained from MERRA-2 at the closest latitude and longitude point to SJ, thereby including stratospheric $\mathrm{O}_{3}$ in the total column calculation. $\mathrm{ML} \mathrm{O}_{3}$ was calculated as the ozonesonde total column $\mathrm{O}_{3}$ value at the top of the ML and tropospheric $\mathrm{O}_{3}$ was the ozonesonde total column $\mathrm{O}_{3}$ value at the tropopause pressure given by MERRA-2. The percent contributions of ML to tropospheric and tropospheric to total column $\mathrm{O}_{3}$ were then computed. 


\section{Results and Discussion}

\subsection{Baseline $\mathrm{O}_{3}$ Climatology}

The percent change of total column $\mathrm{O}_{3}$ (DU) from 2016 to 2018 is presented in Figure 4. The 2017 data did not measure total column, so they have been excluded from the analysis. Each week except July 25 - July 29 had percent decreases in $\mathrm{O}_{3}$, with the largest decrease of $38 \%$ for August 17 . From July 25 - July 29 , there was roughly an $18 \%$ increase.

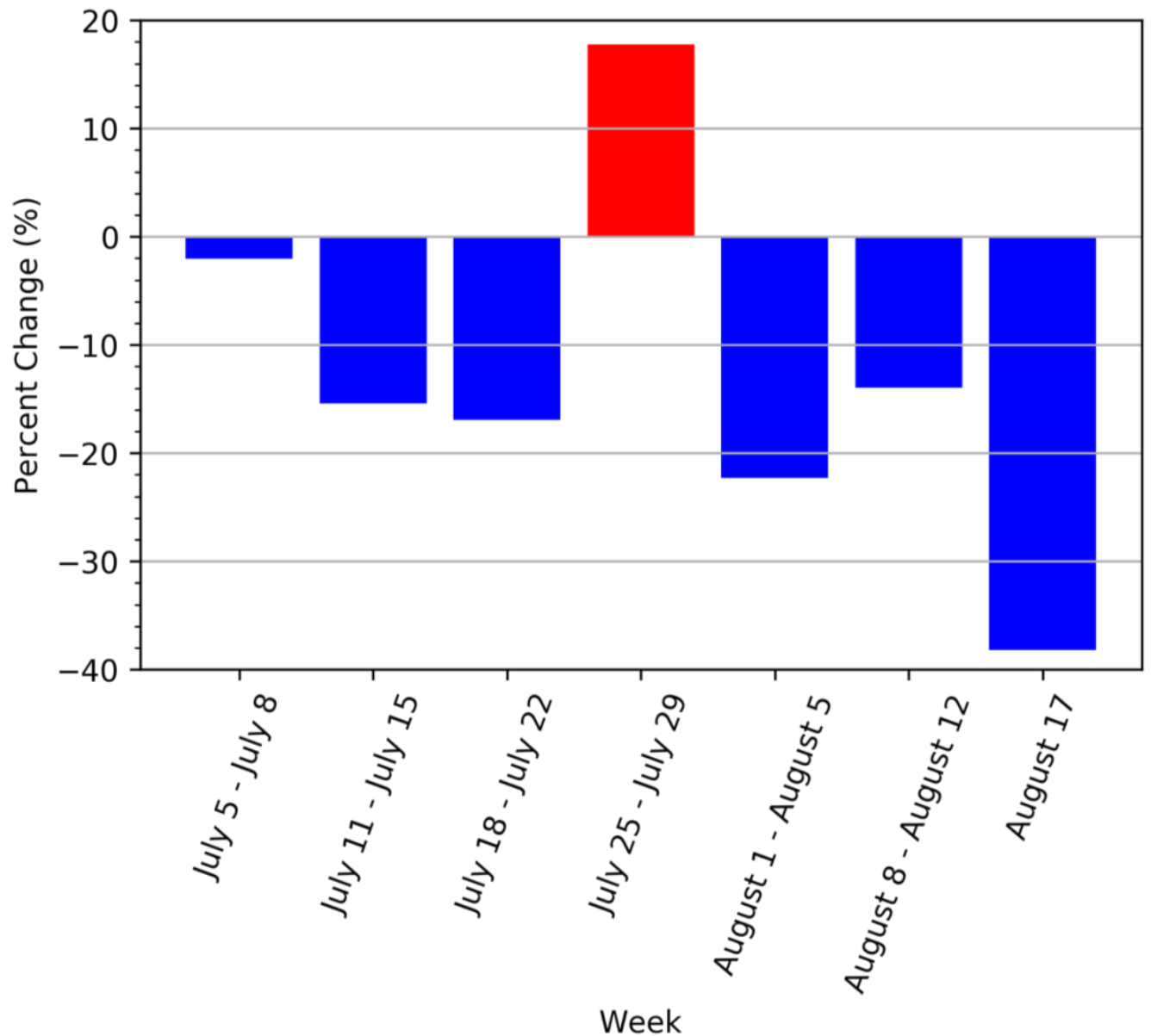

Figure 4. Percent change of total column $\mathrm{O}_{3}$ from 2016 to 2018 for each week in July and the first three weeks in August. 
From 2015 into June of 2016, El Niño conditions were present (Climate Prediction Center). During El Niño, the Pacific Jet Stream is extended and, as a result, can transport more pollution from the Asian continent into the Western U.S. (Lin et al. 2015). At the end of 2017 and into early 2018, La Niña conditions were observed. This leads to Pacific high pressure and a northward shifted polar jet stream. La Niña has also been observed to cause more tropopause folding events, leading to an increase in stratospheric intrusion events for the Western U.S. (Lin et al. 2015).

In July 2016, the average tropopause pressure given as a blended estimate from the MERRA-2 model $\left(0.5^{\circ} \times 0.625^{\circ}\right)$ was roughly $14.1 \mathrm{hPa}$, while in July 2018 it was roughly $11.8 \mathrm{hPa}$. Additionally, July 2016 had a higher average eastward wind component (in ms ${ }^{-1}$ ) at $250 \mathrm{hPa}$ across the Pacific, especially over the Gulf of Alaska and into the Pacific northwest. Over Central California, the July 2016 average $\mathrm{O}_{3}$ mixing ratio at $500 \mathrm{hPa}$ is higher and the transport pathway from the Asian continent is shifted southward, allowing more direct transport as opposed to the northward shifted jet and corresponding northward shift of high $\mathrm{O}_{3}$. This also agrees with the expected jet stream pattern associated with El Niño/La Niña. For August, 2016 had higher average tropopause pressure than 2018. The average eastward wind component was stronger in August 2018, however it was shifted northward over the Gulf of Alaska and into Canada. At $500 \mathrm{hPa}$, the average $\mathrm{O}_{3}$ mixing ratio in August 2016 was slightly higher than 2018 over California.

Although La Niña conditions can increase STEs, the higher tropopause heights in 2018 do not indicate an increase in stratospheric influence from 2016 to 2018. The 
stronger eastward winds in July 2016, coupled with the extended jet stream, likely allowed for an increase in Asian pollution transport, leading to higher $\mathrm{O}_{3}$ in 2016 than 2018. Overall, these conditions led to a decrease in baseline $\mathrm{O}_{3}$ for $\mathrm{HMB}$ from 2016 to 2018.

\subsection{Urban Quantification}

\subsubsection{Enhancement profiles}

Upon initial examination, the enhancement profiles did not show any obvious urban enhancement of $\mathrm{O}_{3}$ aloft (Figure 5). Surface levels were consistently 20-30 ppb higher at SJ, however above the ML, the two profiles matched closely and differences between them remained close to 0 ppbv. On August 10, residual smoke from wildfires to the northeast impacted the $\mathrm{SJ}$ region, enhancing the $\mathrm{O}_{3}$ profile up to the tropopause. Similarly, smoke was visibly present near the surface on August 3, leading to the observed spike in $\mathrm{O}_{3}$ around $1 \mathrm{~km}$. July 31 st was notably greater at $\mathrm{SJ}$ throughout the entire column, however, and will be discussed in further sections. 

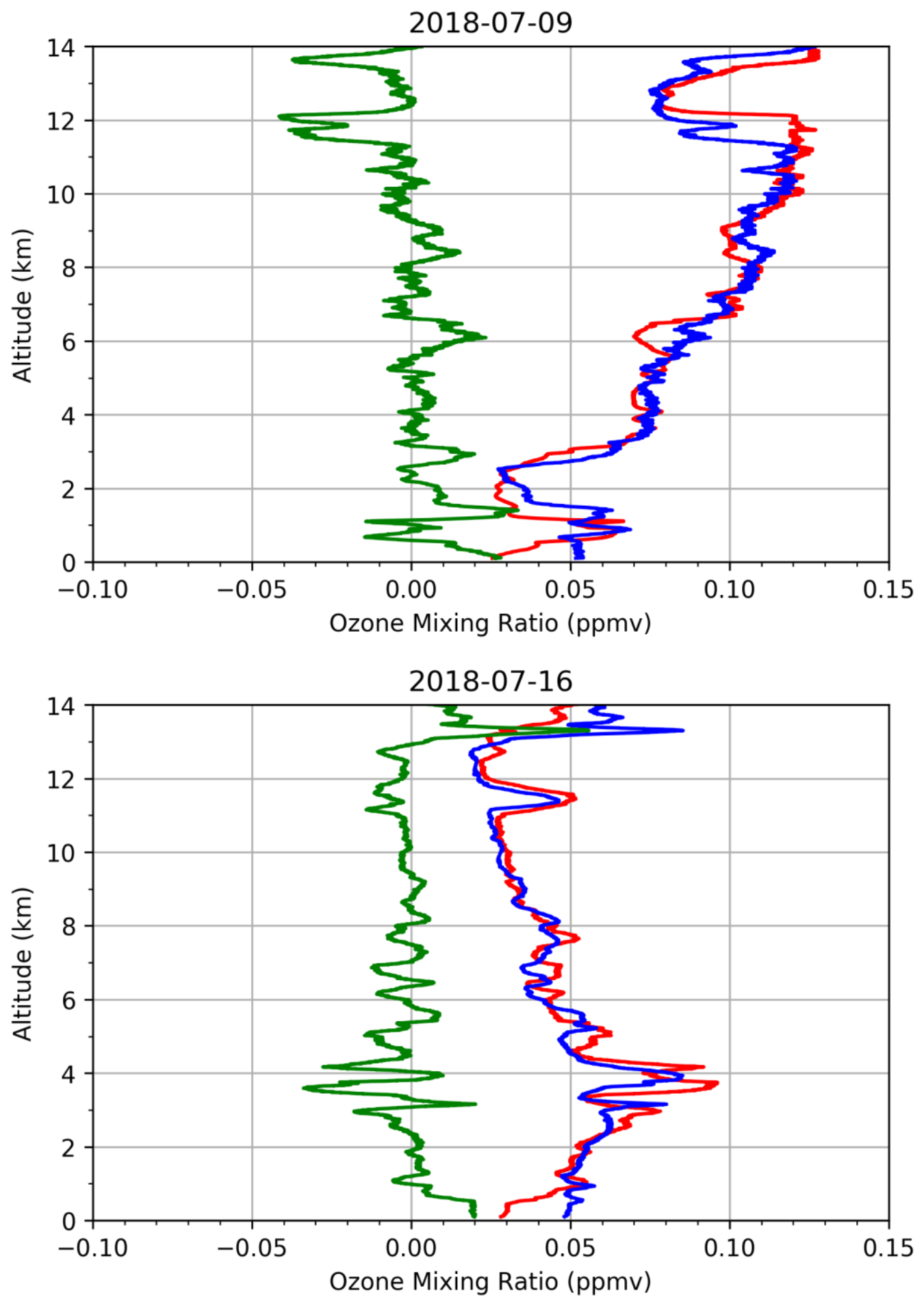

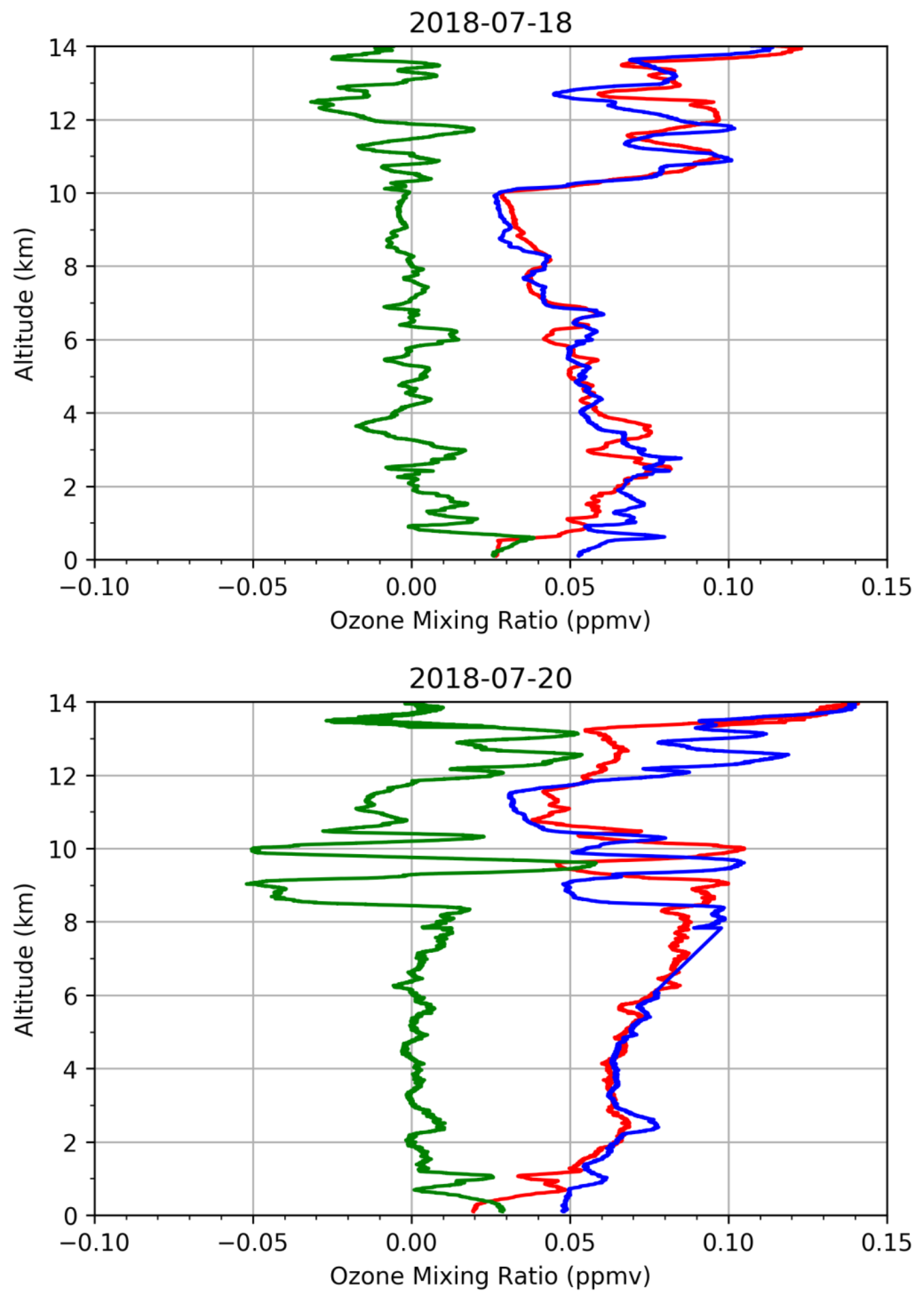

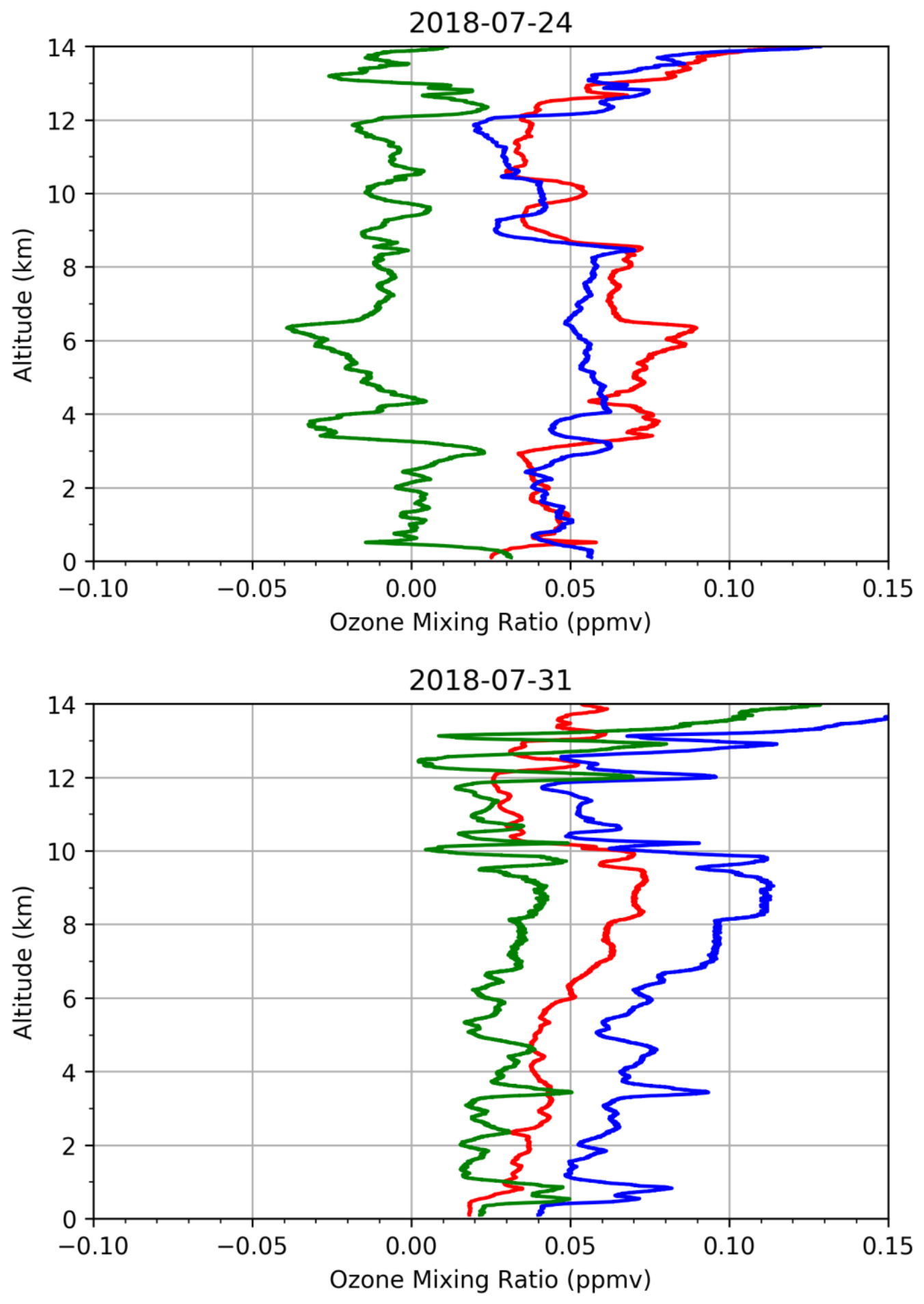

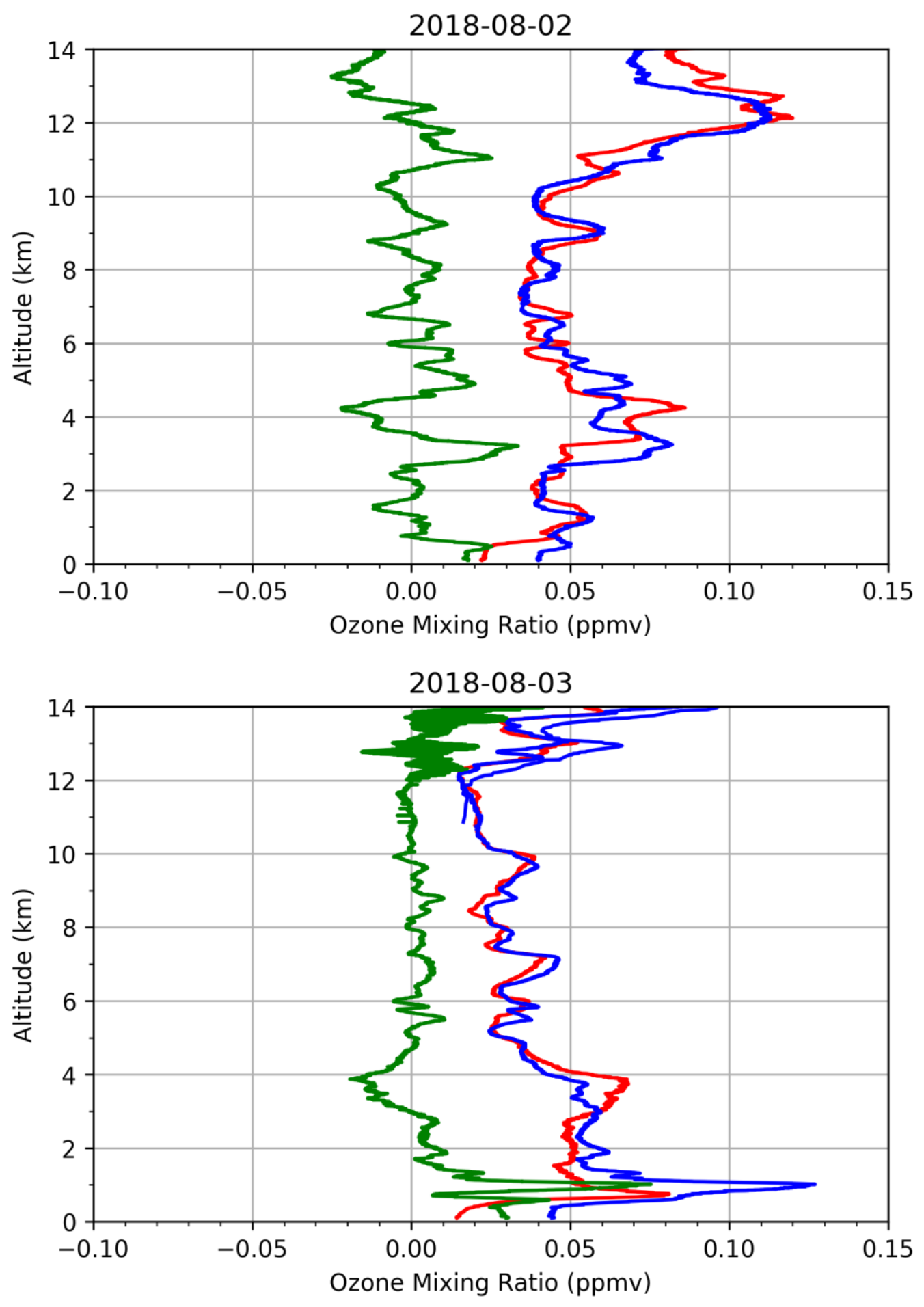

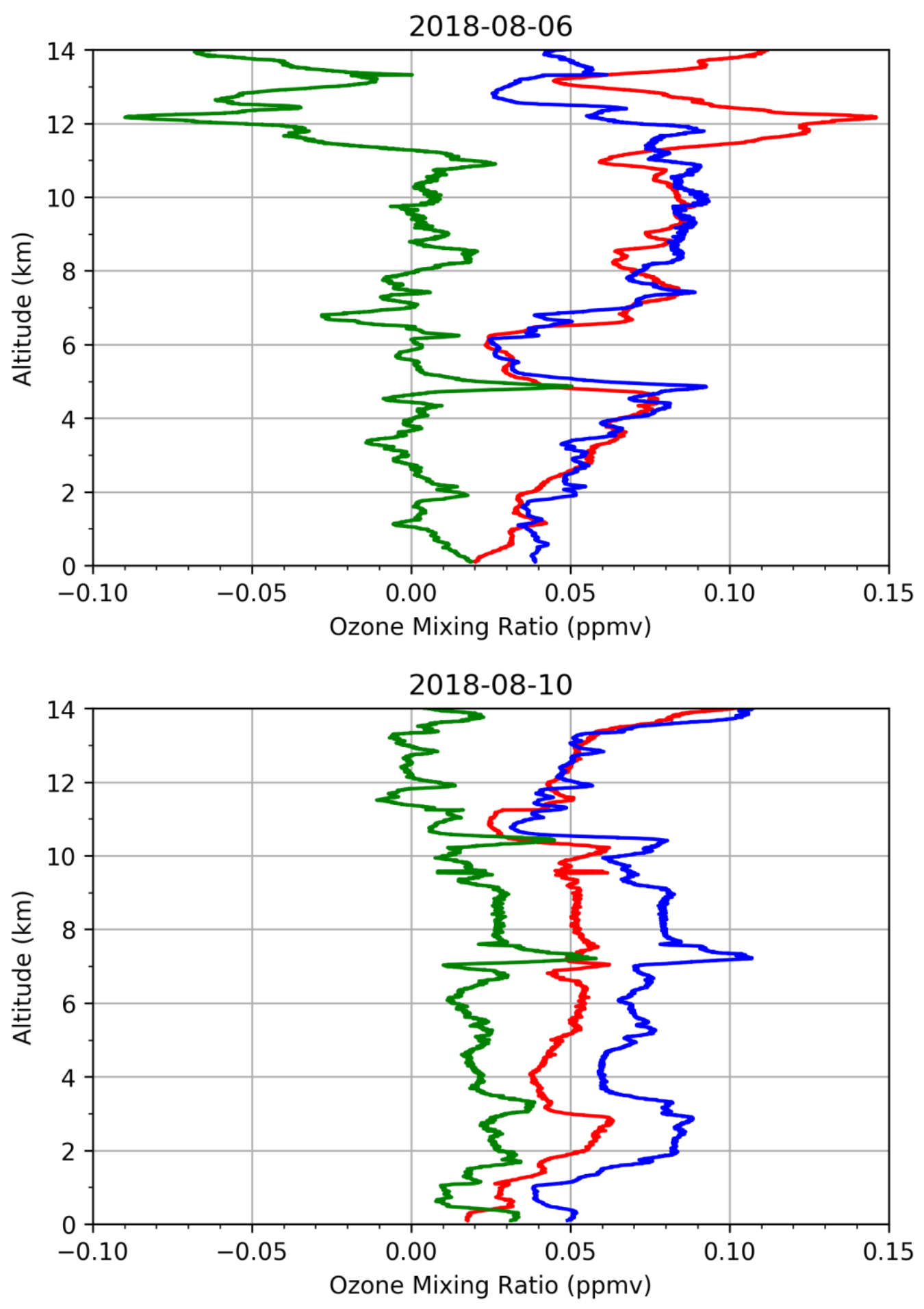


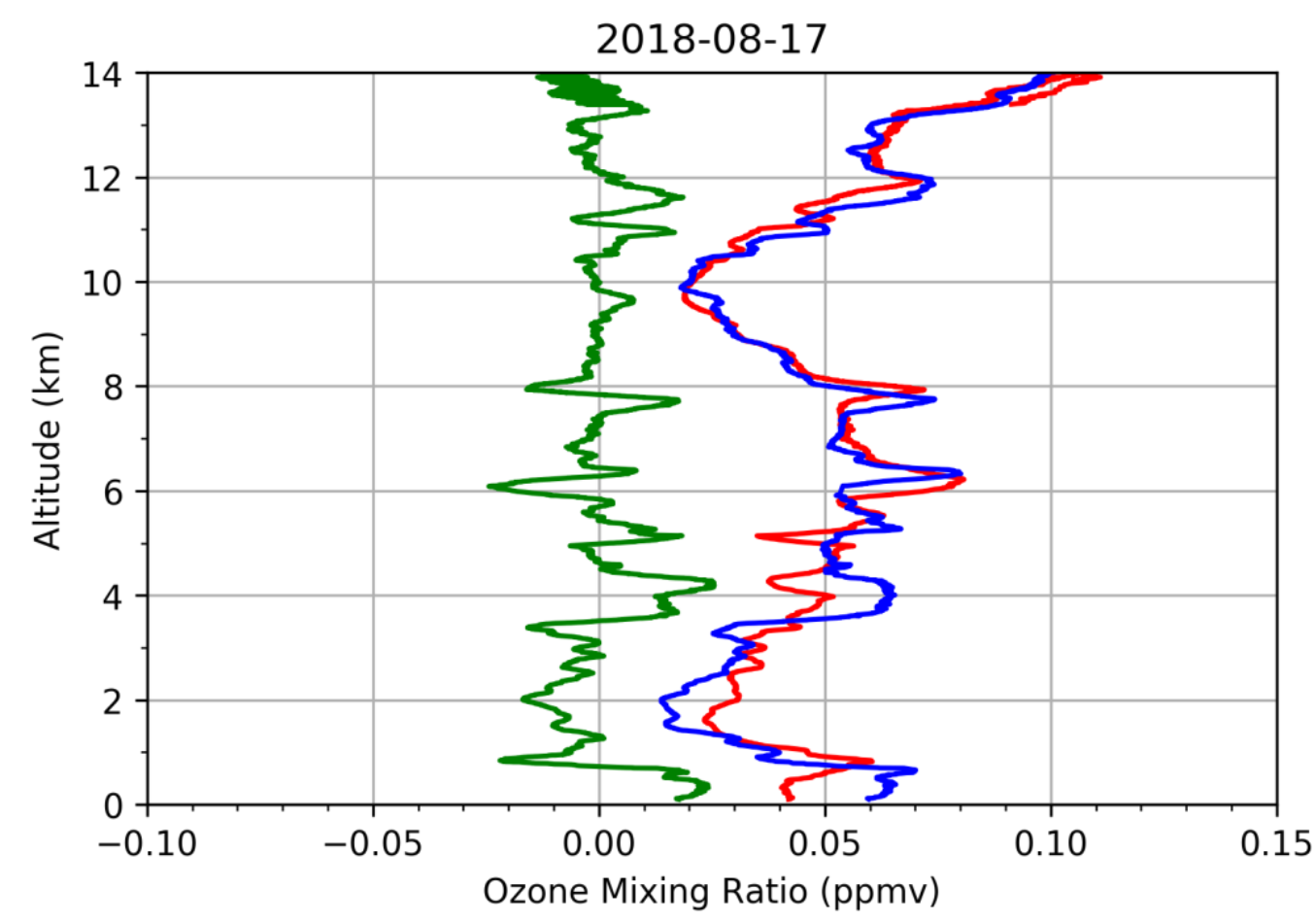

— Half Moon Bay (HMB)

— San Jose (SJ)

— Difference

Figure 5. Ozone profiles of HMB (red), SJ (blue) and the enhancement profile (green) from each launch.

Synoptically, high pressure systems were present over the Southwest for the majority of dates (Figure 6). Low pressure was observed south of Alaska on four of the days and off the coast of the Pacific Northwest on two of the days. The setup of large-scale high pressure to the $\mathrm{SE}$ and low pressure to the $\mathrm{N}$ was conducive to south-westerly to westerly winds at HMB. Lower level wind speeds were consistent between the two sites and remained around $10 \mathrm{~ms}^{-1}$ or below. Upper level wind speeds typically remained between 20 to $30 \mathrm{~ms}^{-1}$, with the strongest winds observed on August 2 and 3 above $11 \mathrm{~km}$. The setup on July 31, August 3, and August 10 is indicative of potential stratospheric 
intrusions (STE), with either a deep trough over the western Pacific (July 31), a trough over the western Pacific resulting in strong upper-level winds over northern California coupled with a cutoff low over the Gulf of Alaska (August 3), or a low off the coast of the Pacific northwest (August 10) (Figure 6). Therefore, these three dates will be investigated in section 3.2.2 for stratospheric influence. While some of the other dates have similar features, the ozonesonde profile did not indicate a STE so they will not be examined individually.

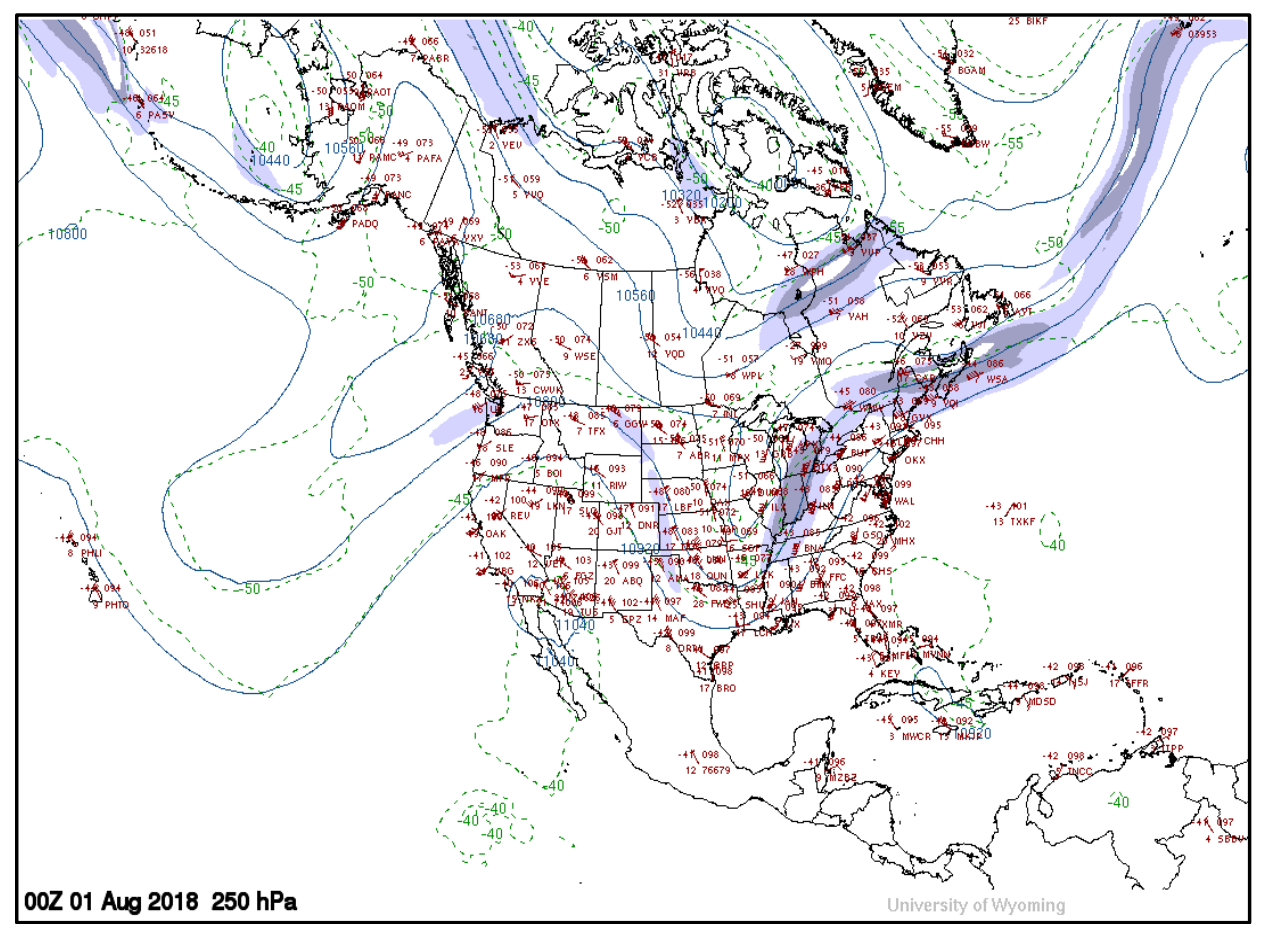



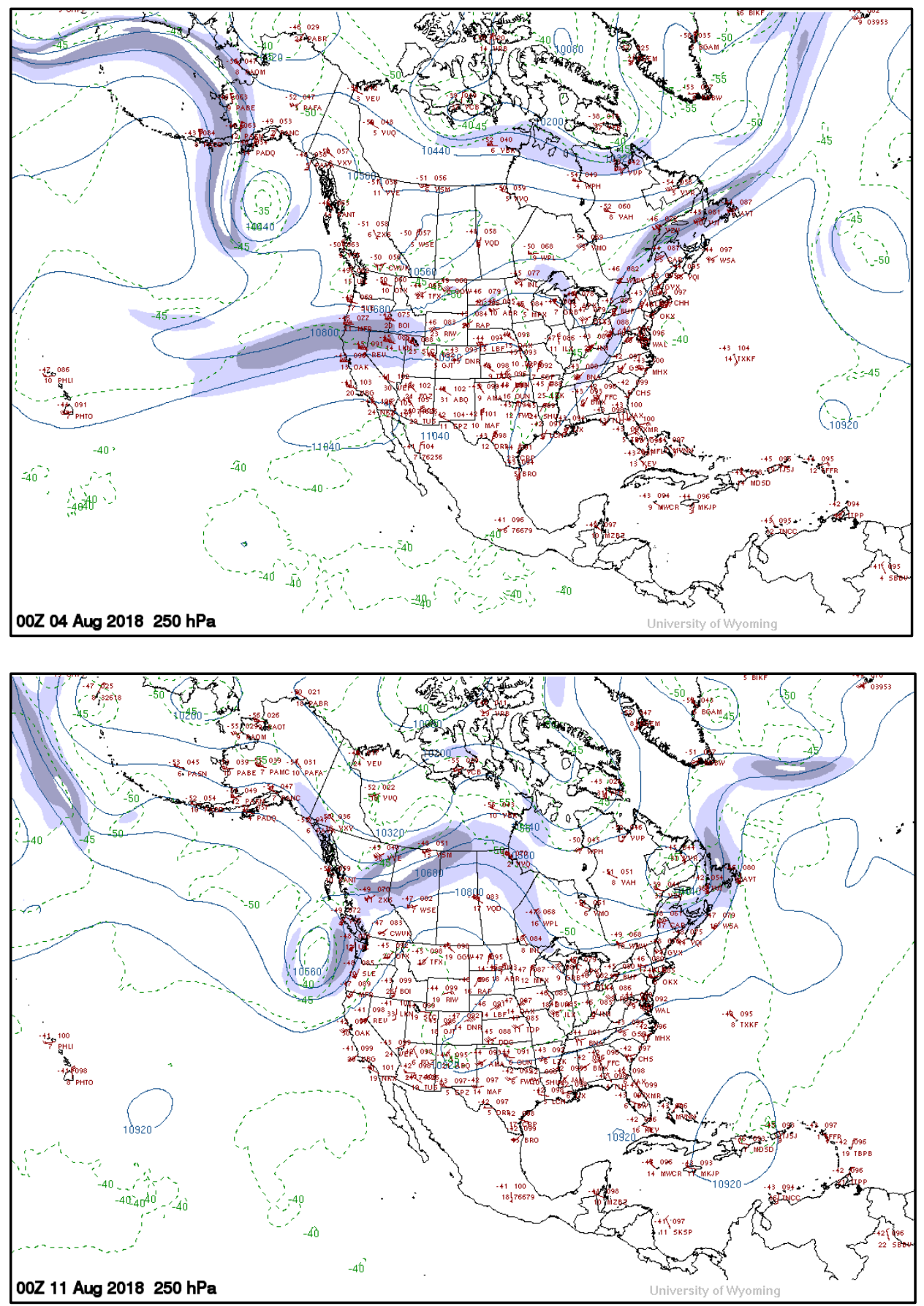

Figure 6. $250 \mathrm{hPa}$ maps for July 31 (top), August 3 (middle), and August 10 (bottom). Images are provided by the University of Wyoming. 


\subsubsection{Stratospheric intrusion cases}

\subsubsection{July 31}

On July $31, \mathrm{SJ} \mathrm{O}_{3}$ is higher than $\mathrm{HMB}$ throughout the entire profile. A positively tilted trough was present off of the coast of the western U.S. At $0.5 \mathrm{~km}$, a steep drop in relative humidity and increase in $\mathrm{O}_{3}$ occurred and at $8 \mathrm{~km}$, a smaller drop in relative humidity and increase in $\mathrm{O}_{3}$ occurred; therefore these two altitudes will be examined for stratospheric air impacts (Figure 7). 

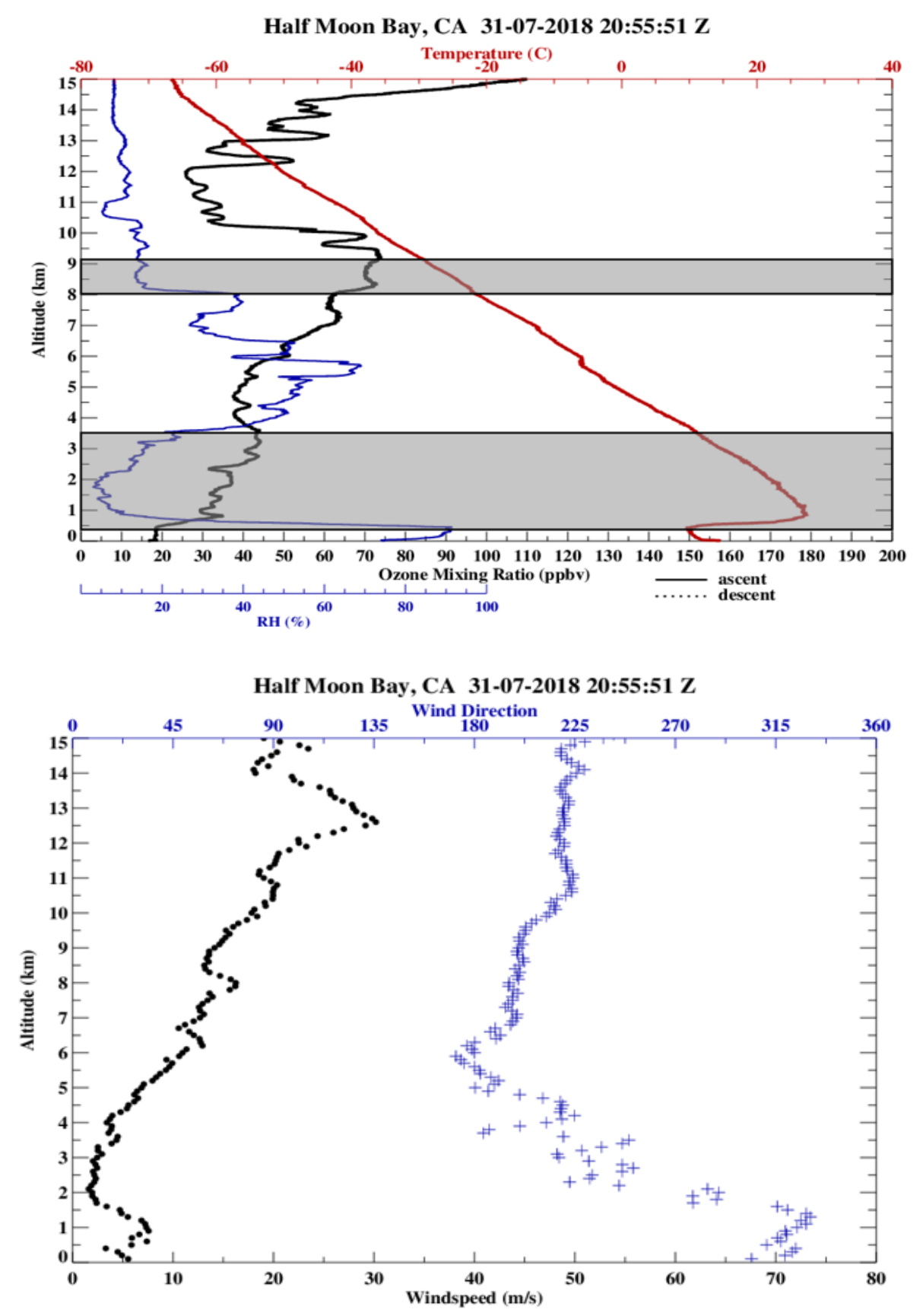

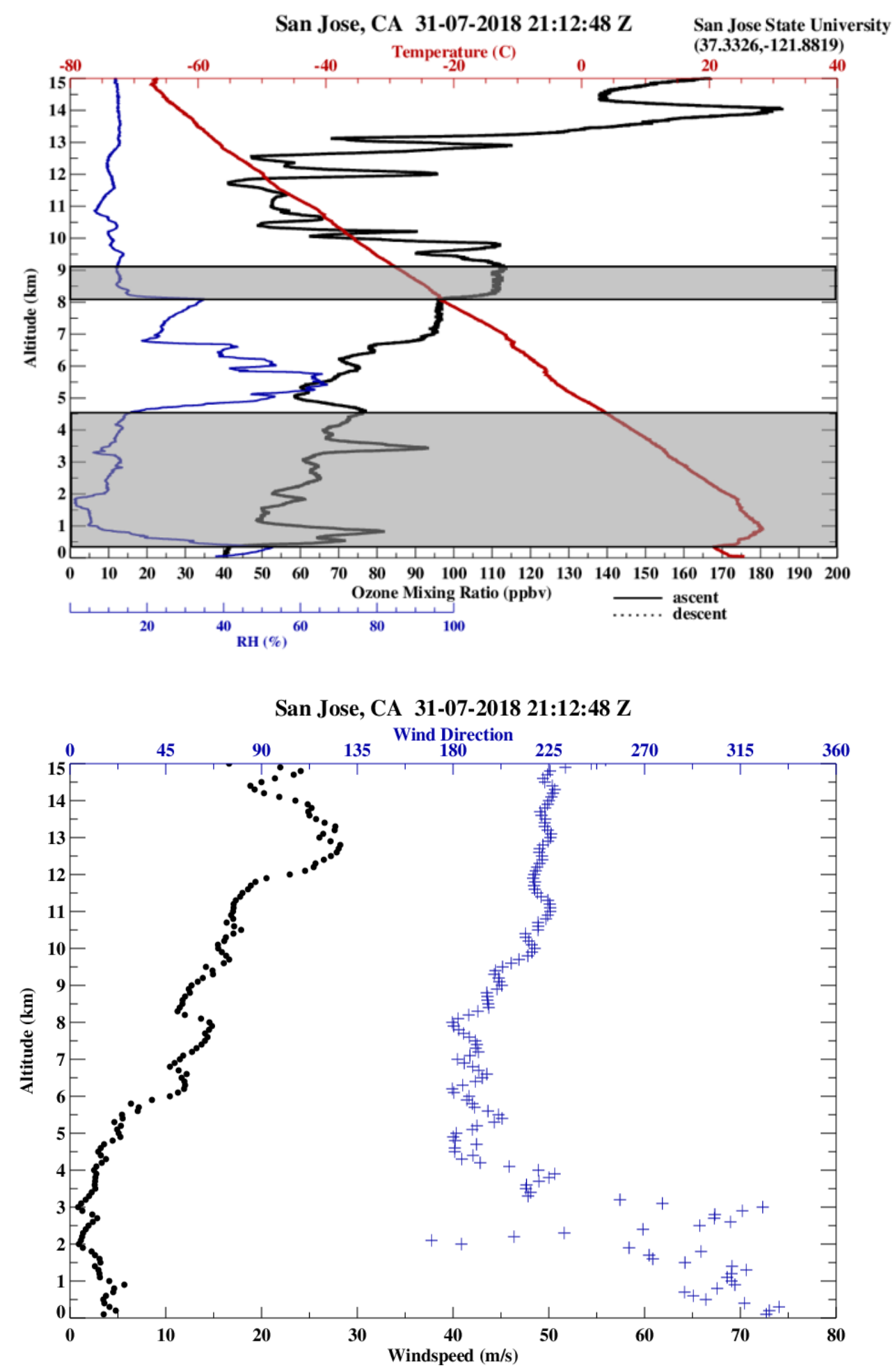

Figure 7. July 31 profiles from HMB (top two) and SJ (bottom two). Gray sections denote potential STE. 
A 1-week HYSPLIT backwards trajectory was computed at $0.5,3.5$, and $8 \mathrm{~km}$ to compare the vertical transport of the air masses at the two $\mathrm{O}_{3}$ peaks $(0.5$ and $8 \mathrm{~km})$ and a non-stratospheric influenced level $(3.5 \mathrm{~km}$ ) (Figure 8). For both SJ and HMB, the $0.5 \mathrm{~km}$ back trajectory showed a steep vertical descent during the week prior to July 31 . At 3.5 and $8 \mathrm{~km}$, there is not strong descent to indicate a STE; therefore $8 \mathrm{~km}$ is not stratospherically influenced.

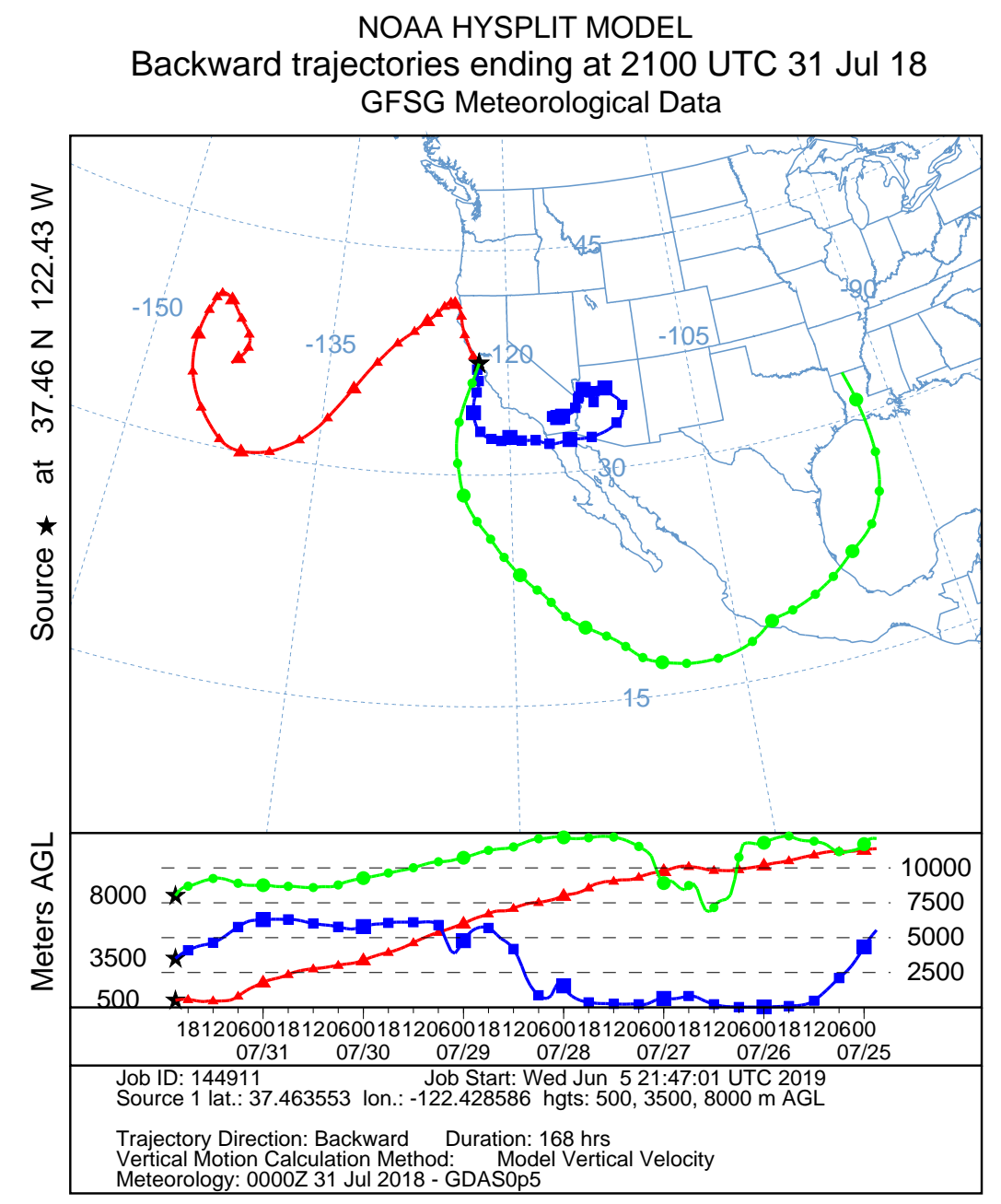




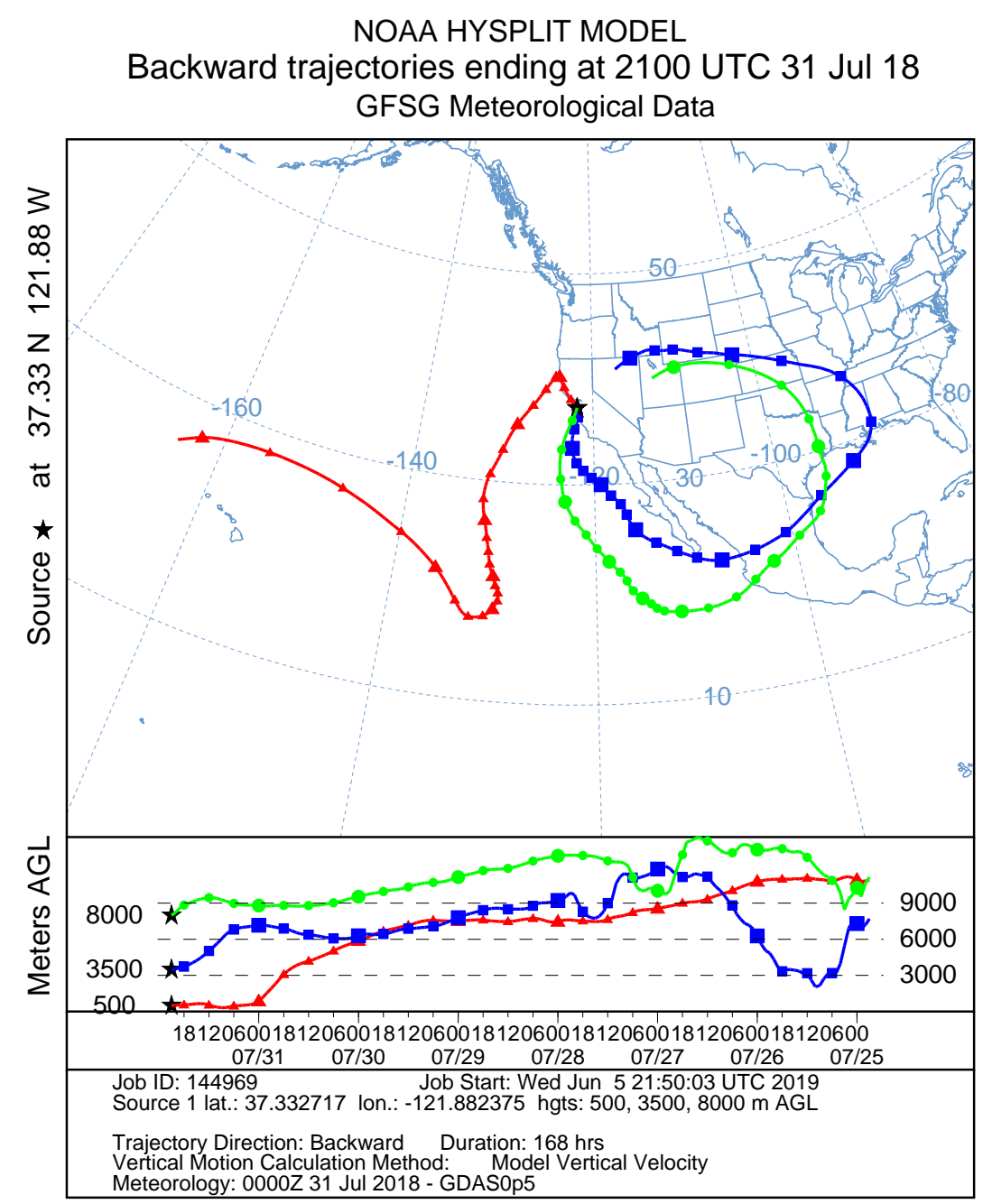

Figure 8. July 31 HYSPLIT back trajectory from HMB (top) and SJ (bottom) at STE altitudes.

To further confirm stratospheric influence following the methods of Ryoo et al. 2017, a correlation analysis was computed between relative humidity and $\mathrm{O}_{3}$ from 0 to $10 \mathrm{~km}$ (Figure 9). The highest $\mathrm{O}_{3}$ concentrations were observed above roughly $7 \mathrm{~km}$ at relative humidity between $10-20 \%$. The low-level spike in $\mathrm{O}_{3}$ corresponding with a steep drop in relative humidity is observed for both HMB and SJ. Furthermore, a Realtime Air Quality Modeling System (RAQMS) longitudinal cross section of $\mathrm{O}_{3}$ at $40^{\circ} \mathrm{N}$ was also examined 
(Figure 10). High $\mathrm{O}_{3}$ concentrations near $200 \mathrm{hPa}$ extend downward into the inland region, indicating a mild STE.
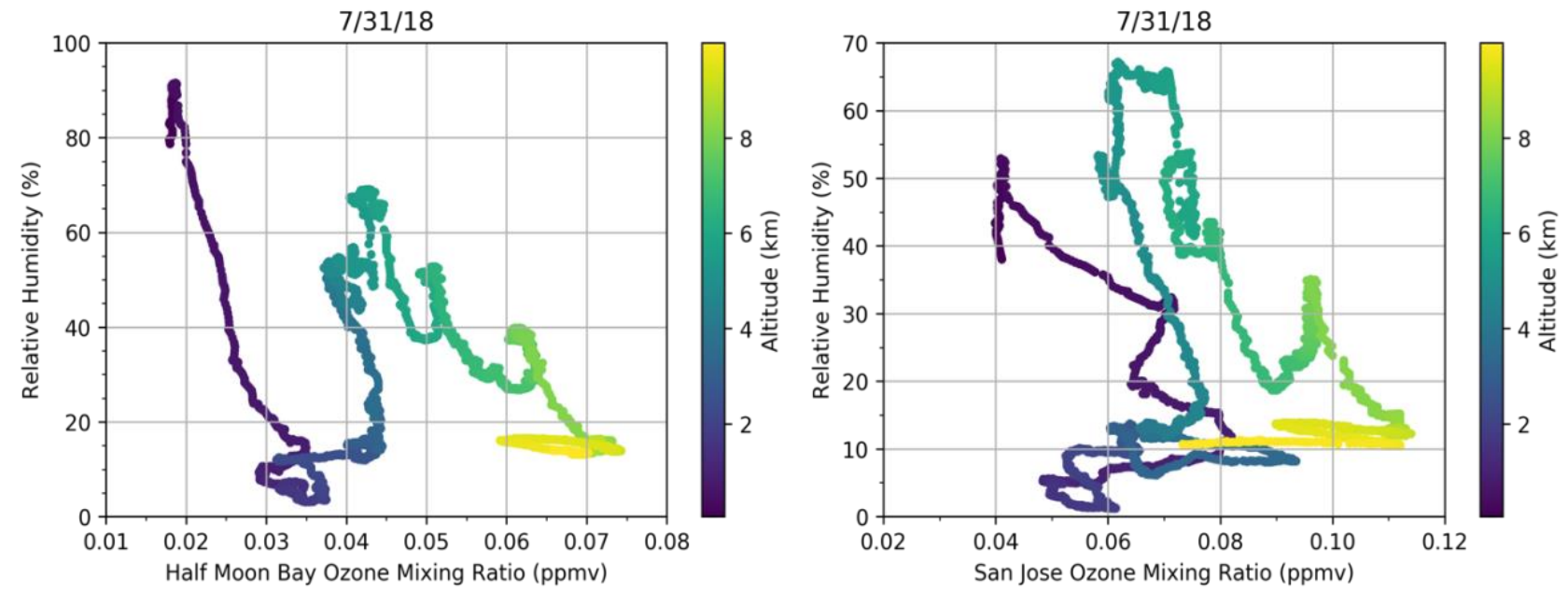

Figure 9. July 31 scatterplots of relative humidity and $\mathrm{O}_{3}$ for $\mathrm{HMB}$ (left) and $\mathrm{SJ}$ (right).

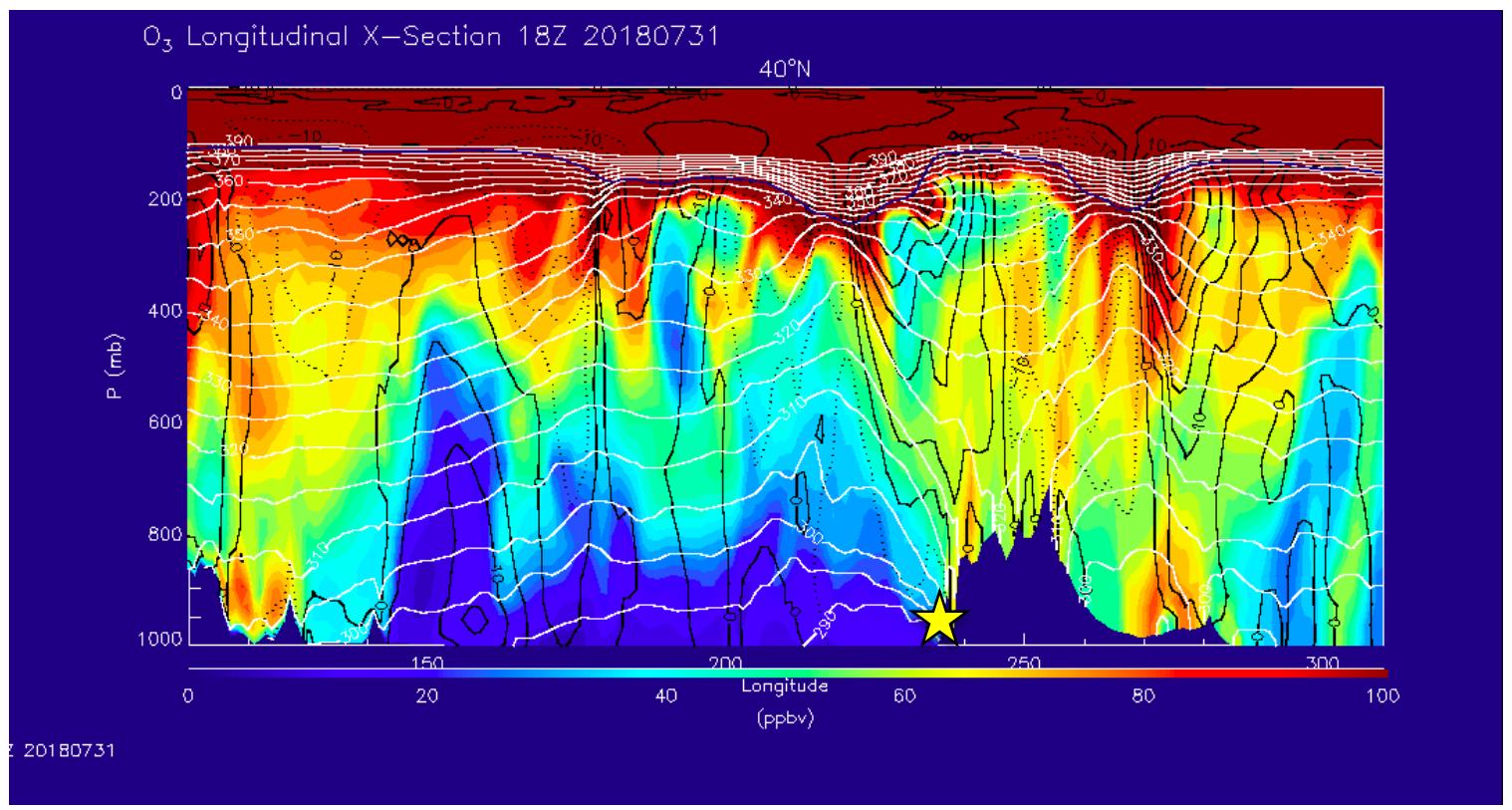

Figure 10. July 31 RAQMS longitudinal cross section of $\mathrm{O}_{3}$ at $40^{\circ} \mathrm{N}$. Location of $\mathrm{SJ}$ is denoted by the yellow star.

\subsubsection{August 3}

A large spike in $\mathrm{O}_{3}$ occurred at roughly $0.5 \mathrm{~km}$ on August 3 (Figure 11). The backwards HYSPLIT trajectories beginning at 50 and $500 \mathrm{~m}$ both originated from the 
north of the state, moving over regions of high smoke from wildfires (Figure 12). At 500 $\mathrm{m}$ and $2 \mathrm{~km}$, the air descended during the days leading up to launch. Synoptically, a strong jet at $250 \mathrm{hPa}$ was present over the north half of the state and a low-pressure center was just south of Alaska.

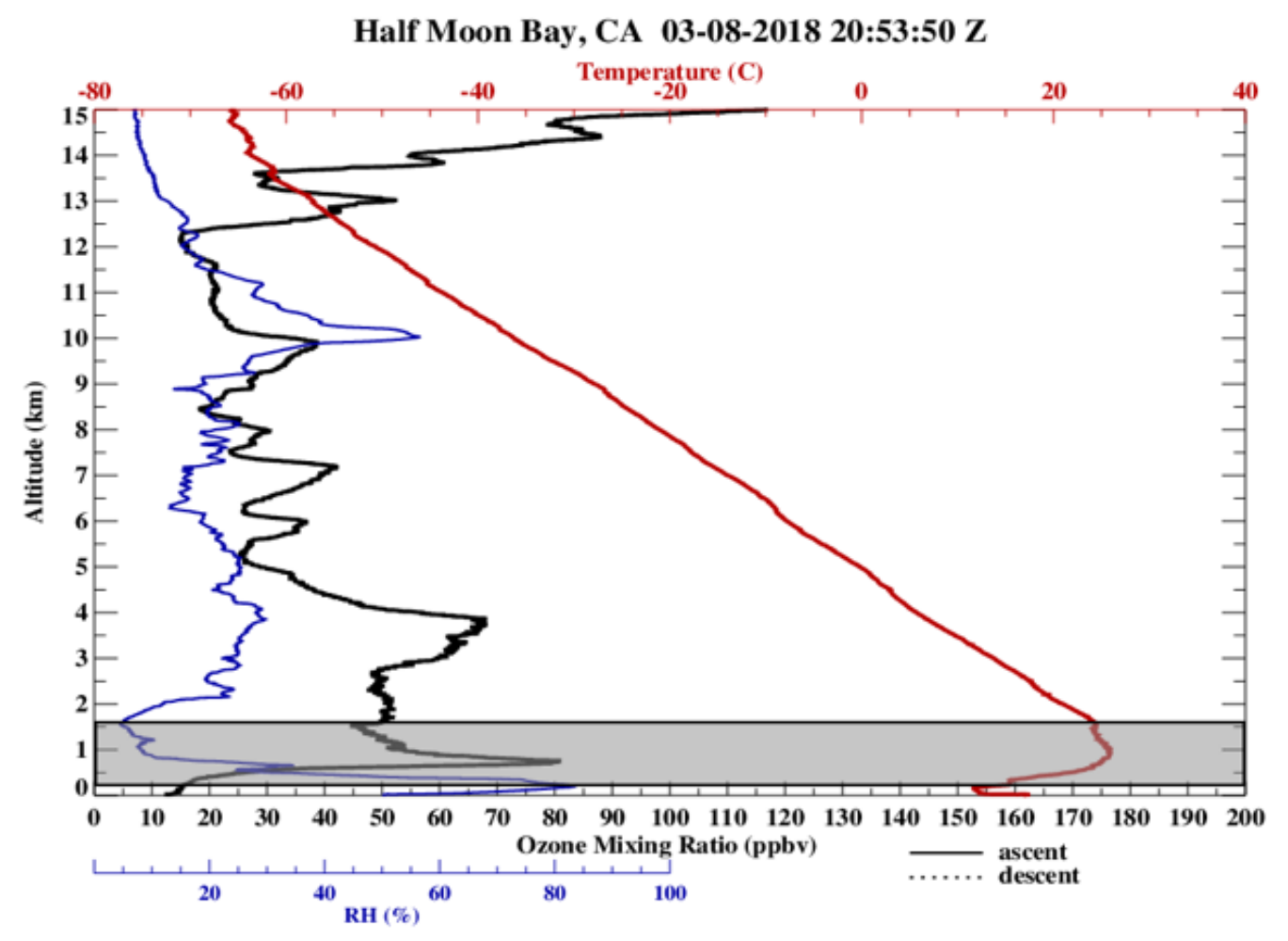


Half Moon Bay, CA 03-08-2018 20:53:50 Z

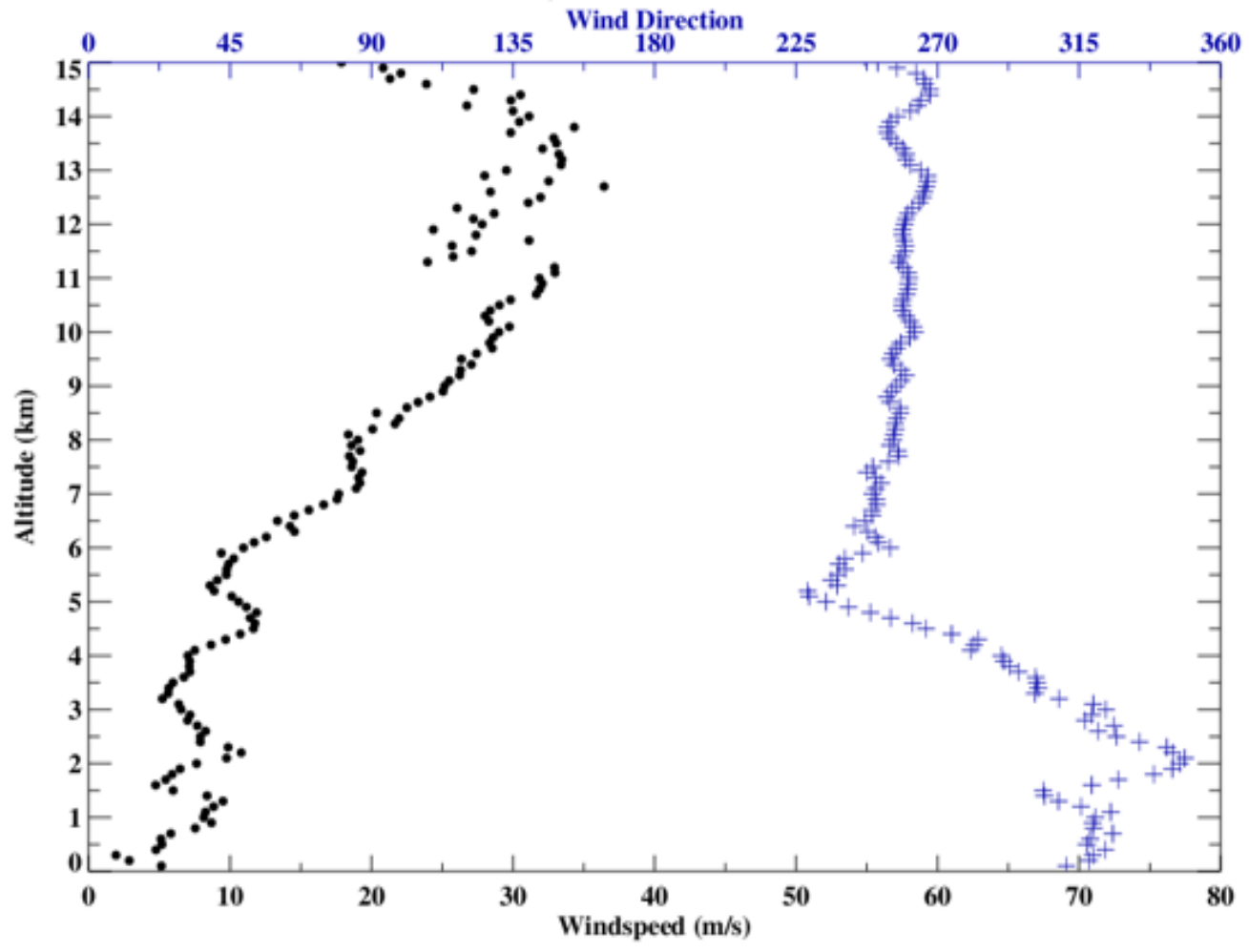

San Jose, CA 03-08-2018 21:12:32 Z San Jose State University

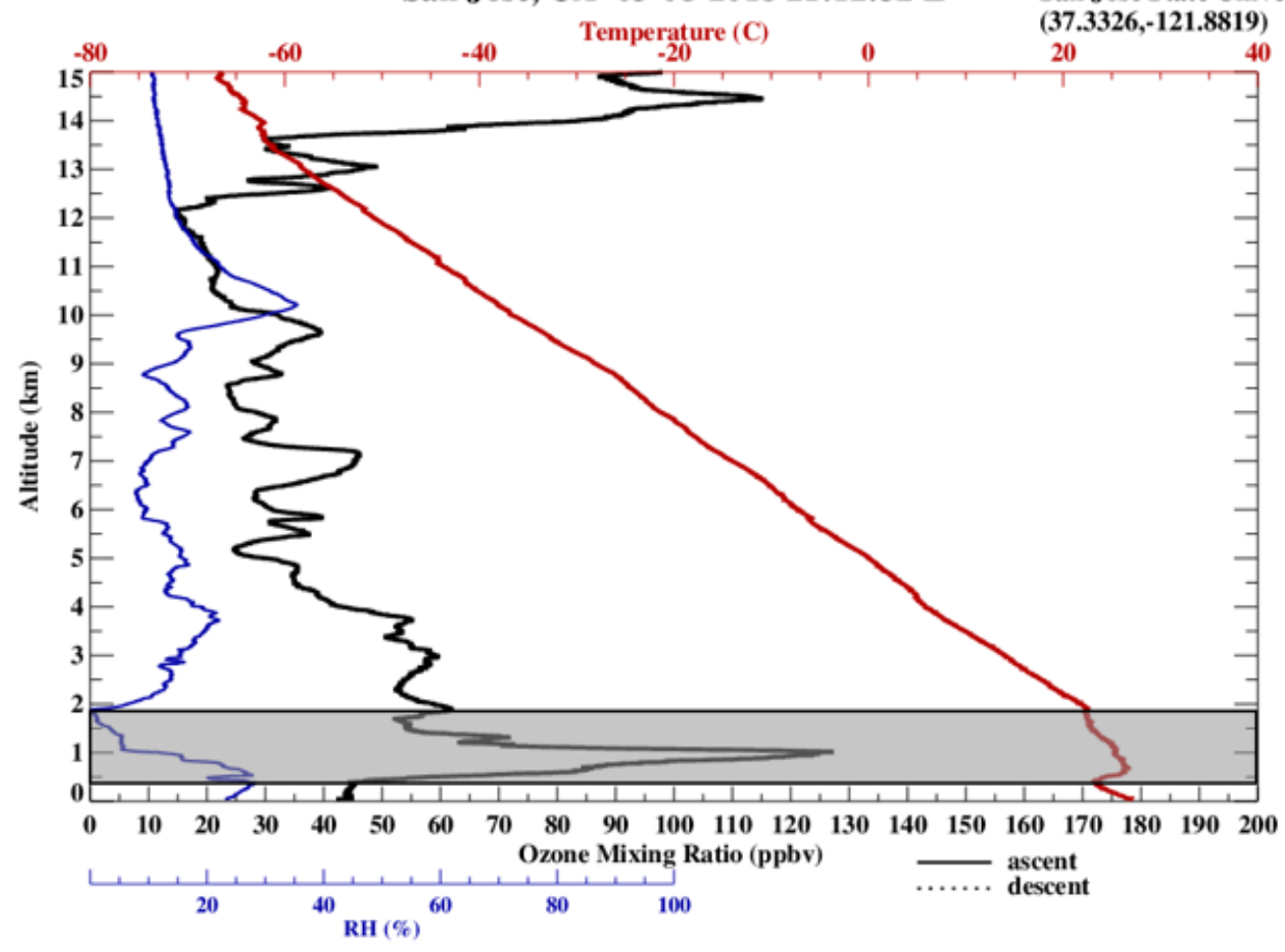




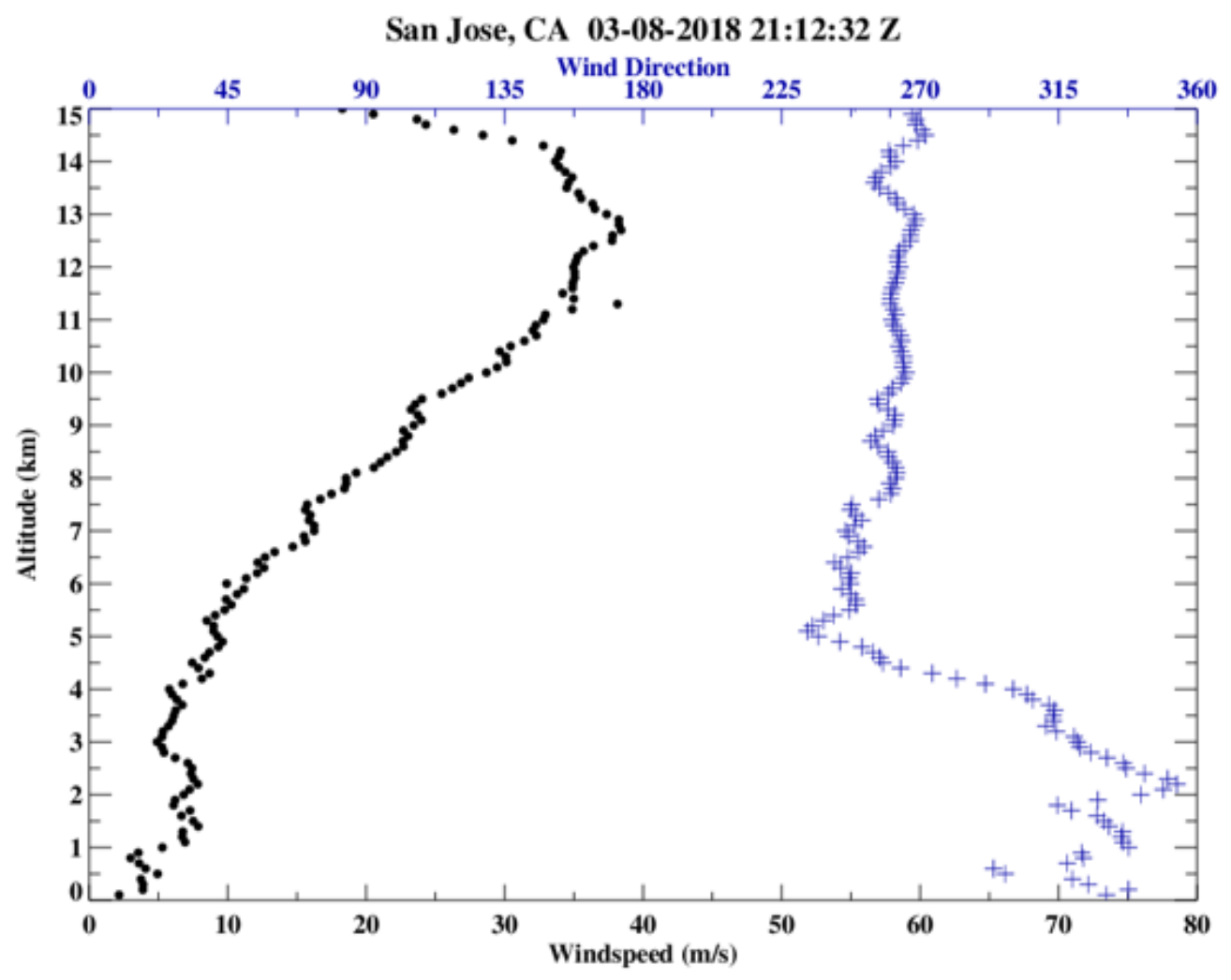

Figure 11. August 3 profiles from HMB (top) and SJ (bottom). Gray sections denote potential STE. 
NOAA HYSPLIT MODEL

Backward trajectories ending at 2100 UTC 03 Aug 18 GFSG Meteorological Data

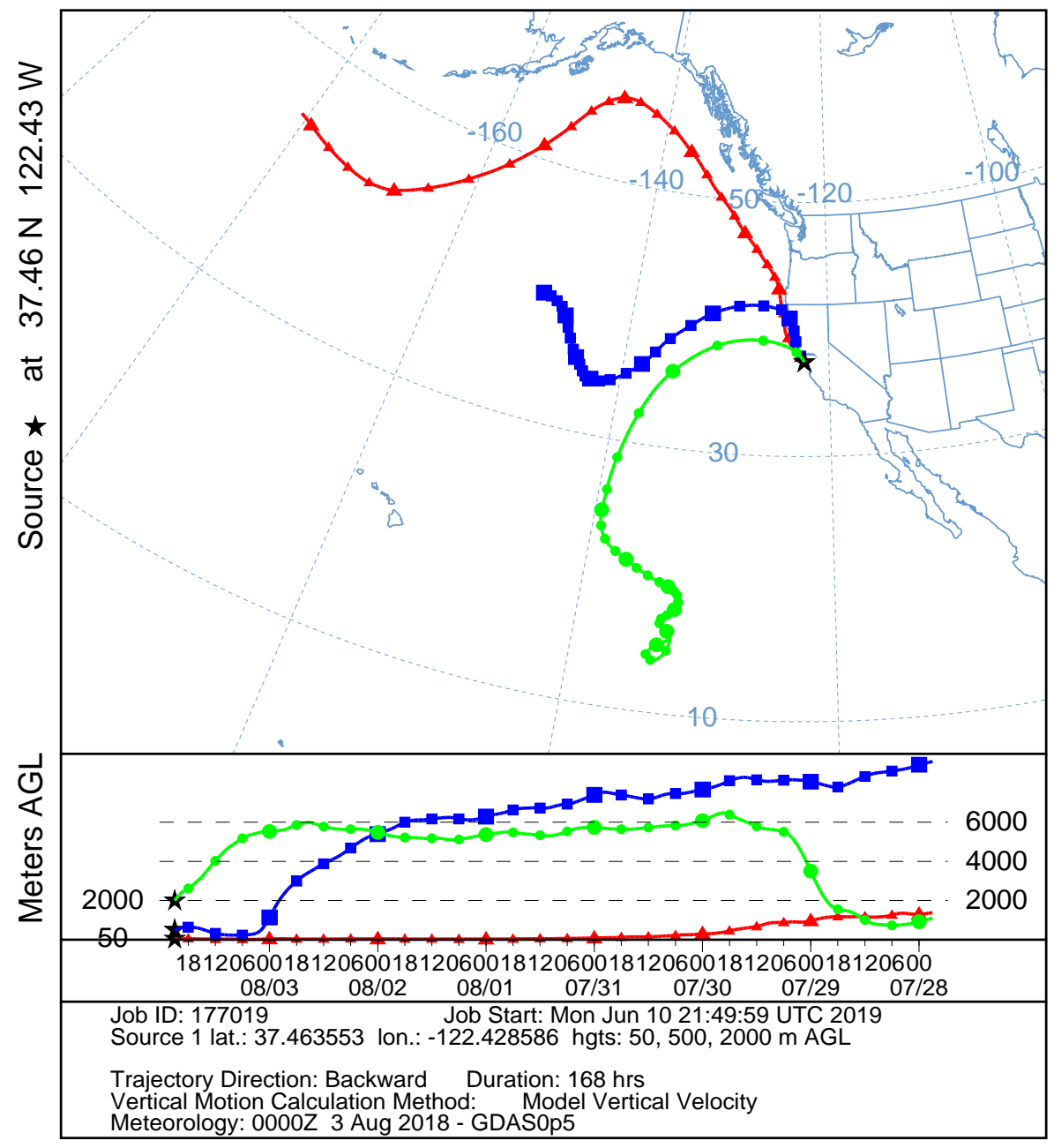




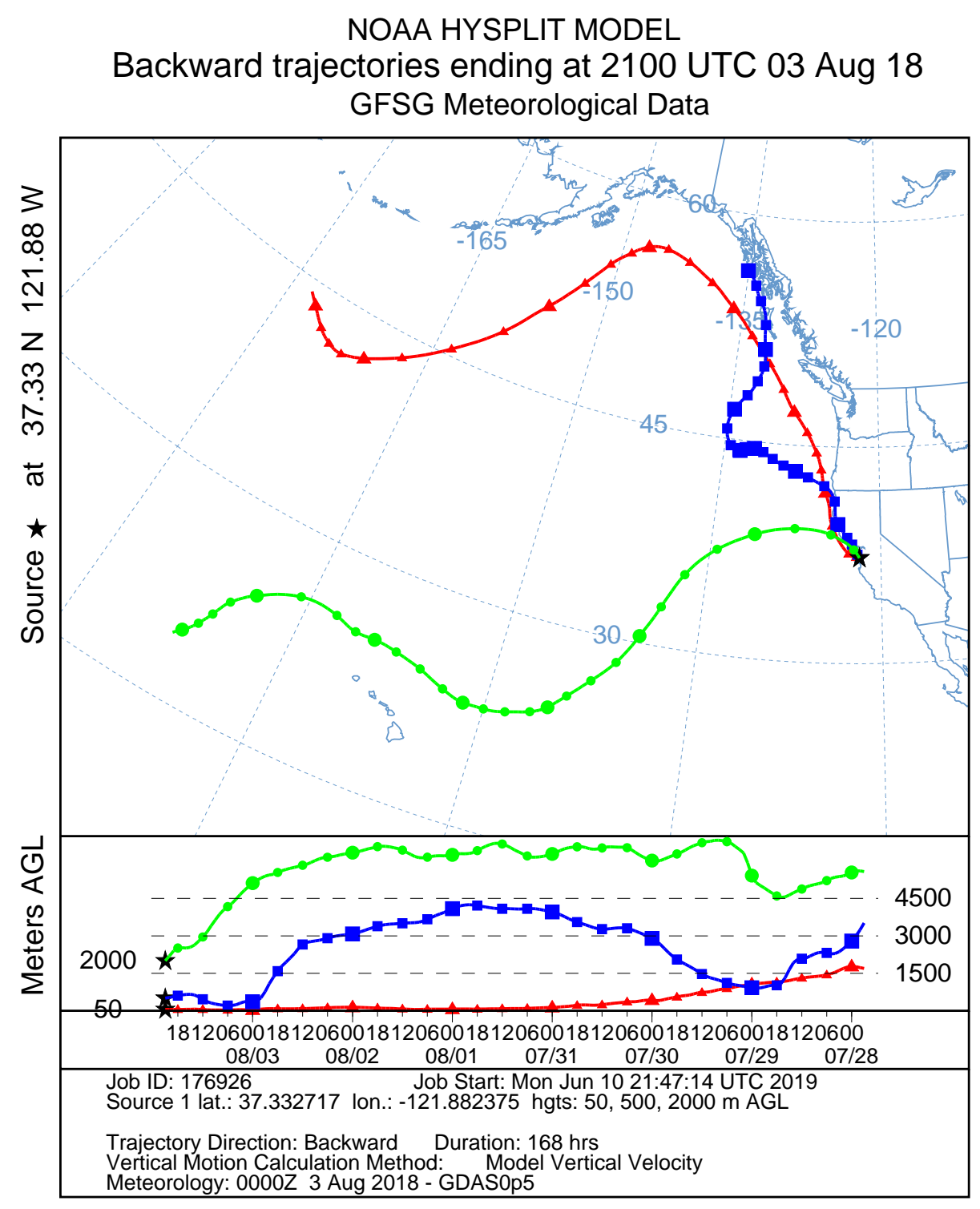

Figure 12. August 3 HYSPLIT back trajectory from HMB (top) and SJ (bottom) at STE altitudes.

From the scatterplots of relative humidity and $\mathrm{O}_{3}$, at $\mathrm{SJ}$ the highest $\mathrm{O}_{3}$ concentrations were observed at the lowest relative humidity (Figure 13). $\mathrm{HMB}$ is more varied, with $\mathrm{O}_{3}$ concentrations between $30-80 \mathrm{ppb}$ present for relative humidity of $20 \%$. The RAQMS cross section revealed transport of $\mathrm{O}_{3}$ aloft into the region, however concentrations were 
lower in this case (Figure 14). There is evidence of a mild STE occurring on this date, leading to the $\mathrm{O}_{3}$ peak at $\mathrm{HMB}$, however the spike in $\mathrm{O}_{3}$ at $\mathrm{SJ}$ is concluded to be the combined result of stratospheric air and residual smoke transported into the area from the north, resulting in $\mathrm{SJ} \mathrm{O}_{3}$ of 50 ppb higher than $\mathrm{HMB}$.
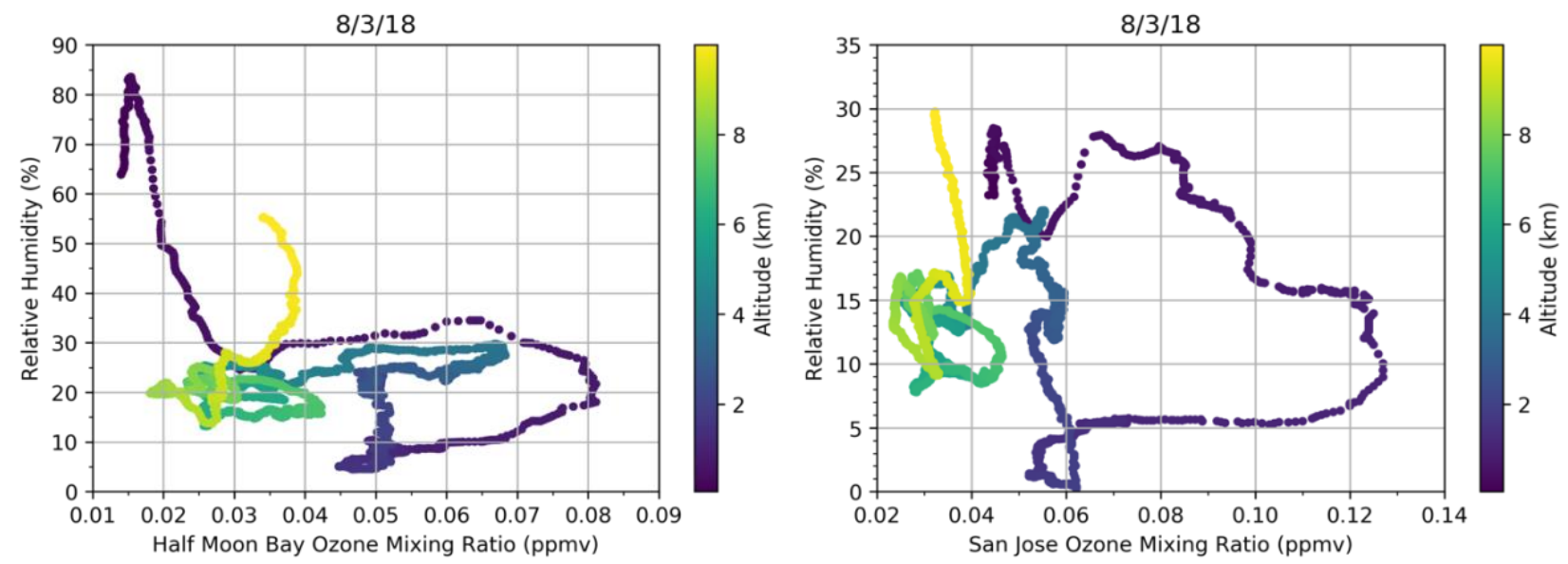

Figure 13. August 3 scatterplots of relative humidity and $\mathrm{O}_{3}$ for $\mathrm{HMB}$ (left) and $\mathrm{SJ}$ (right).

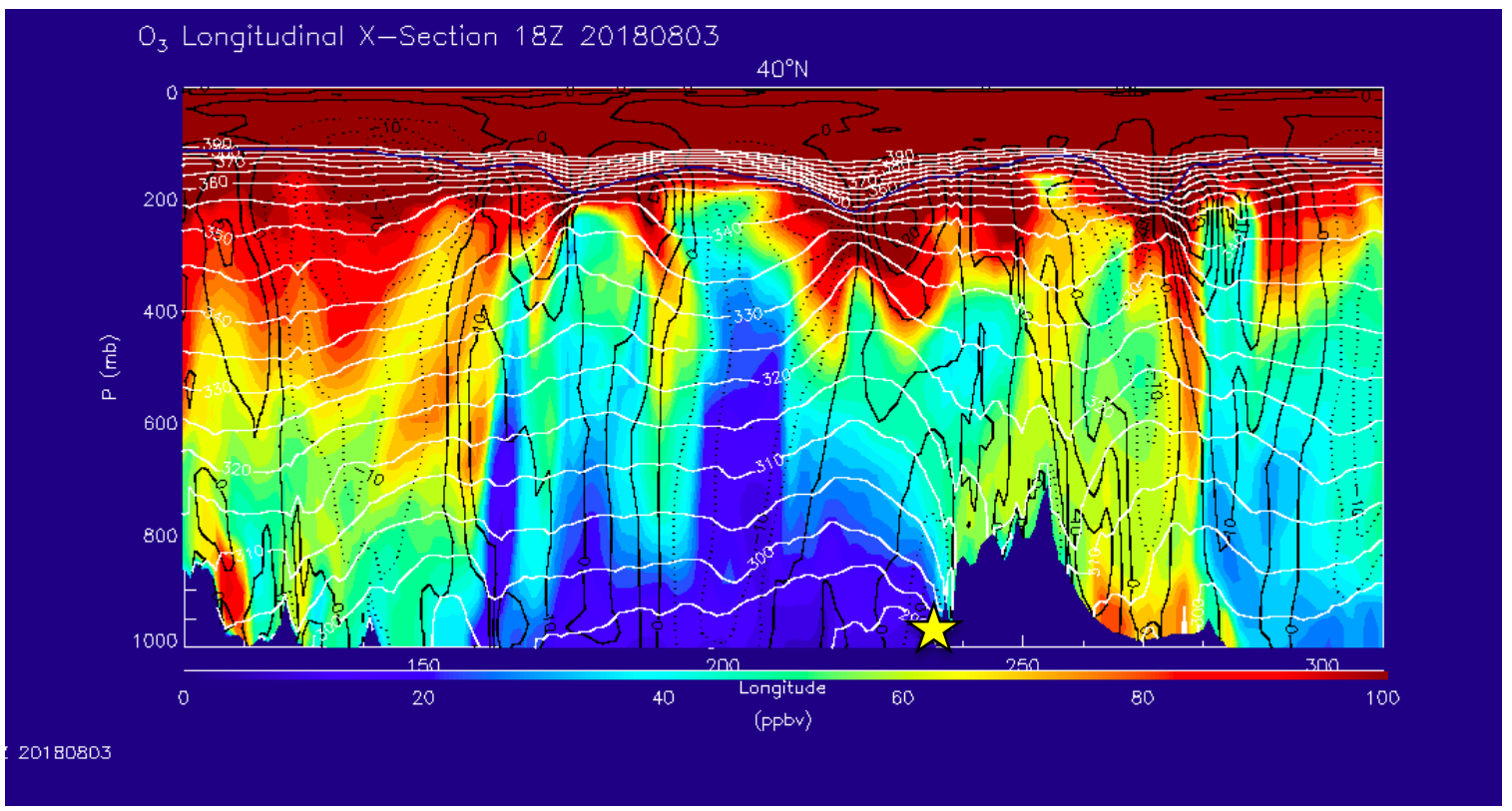

Figure 14. August 3 RAQMS longitudinal cross section of $\mathrm{O}_{3}$ at $40^{\circ} \mathrm{N}$. Location of $\mathrm{SJ}$ is denoted by the yellow star. 


\subsubsection{August 10}

On August 10, from the surface to about $10 \mathrm{~km}, \mathrm{SJ} \mathrm{O}_{3}$ is higher than $\mathrm{HMB}$ by roughly 20-30 ppb. The radiosonde relative humidity profile shows a drop in relative humidity from 2-3 km and $7 \mathrm{~km}$ corresponding with an increase in $\mathrm{O}_{3}$, which is indicative of stratospheric air (Figure 15). Synoptically, a low-pressure center was positioned off the coast of the Pacific Northwest. A 1-week HYSPLIT backwards trajectory was computed at 2, 4, and $7 \mathrm{~km}$ to compare the vertical transport of the air masses at the two $\mathrm{O}_{3}$ peaks (2 and $7 \mathrm{~km}$ ) and a non-stratospheric influenced level (4 km) (Figure 16). At both HMB and $\mathrm{SJ}$, the air mass at 2 and $7 \mathrm{~km}$ originated at higher altitudes and descended during the days leading up to August 10. At HMB, the $4 \mathrm{~km}$ air came from surface levels before ascending on August 8 and at SJ, air originated from roughly $6 \mathrm{~km}$ before dropping to near surface on August 8 and ascending into the region by August 10. The 2 and $4 \mathrm{~km} \mathrm{SJ}$ back trajectories moved over the continent and $4 \mathrm{~km} \mathrm{HMB}$ trajectory followed the west coast of California and Mexico. Therefore, SJ had a higher anthropogenic influence in addition to stratospheric $\mathrm{O}_{3}$. This, coupled with the residual smoke at SJ on August 10, led to higher $\mathrm{SJ} \mathrm{O}_{3}$ from the surface to the tropopause. 
Half Moon Bay, CA 10-08-2018 20:59:28 Z

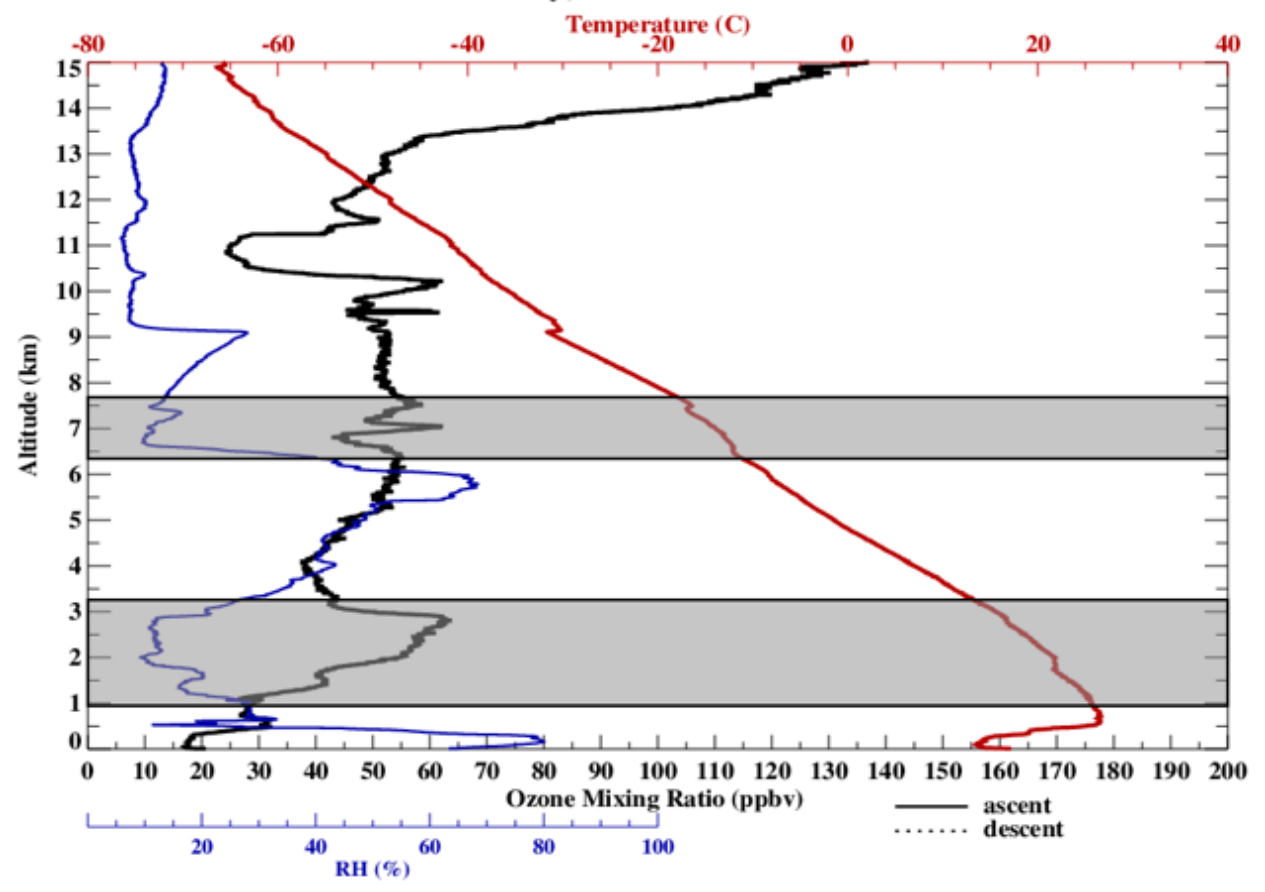

Half Moon Bay, CA 10-08-2018 20:59:28 Z

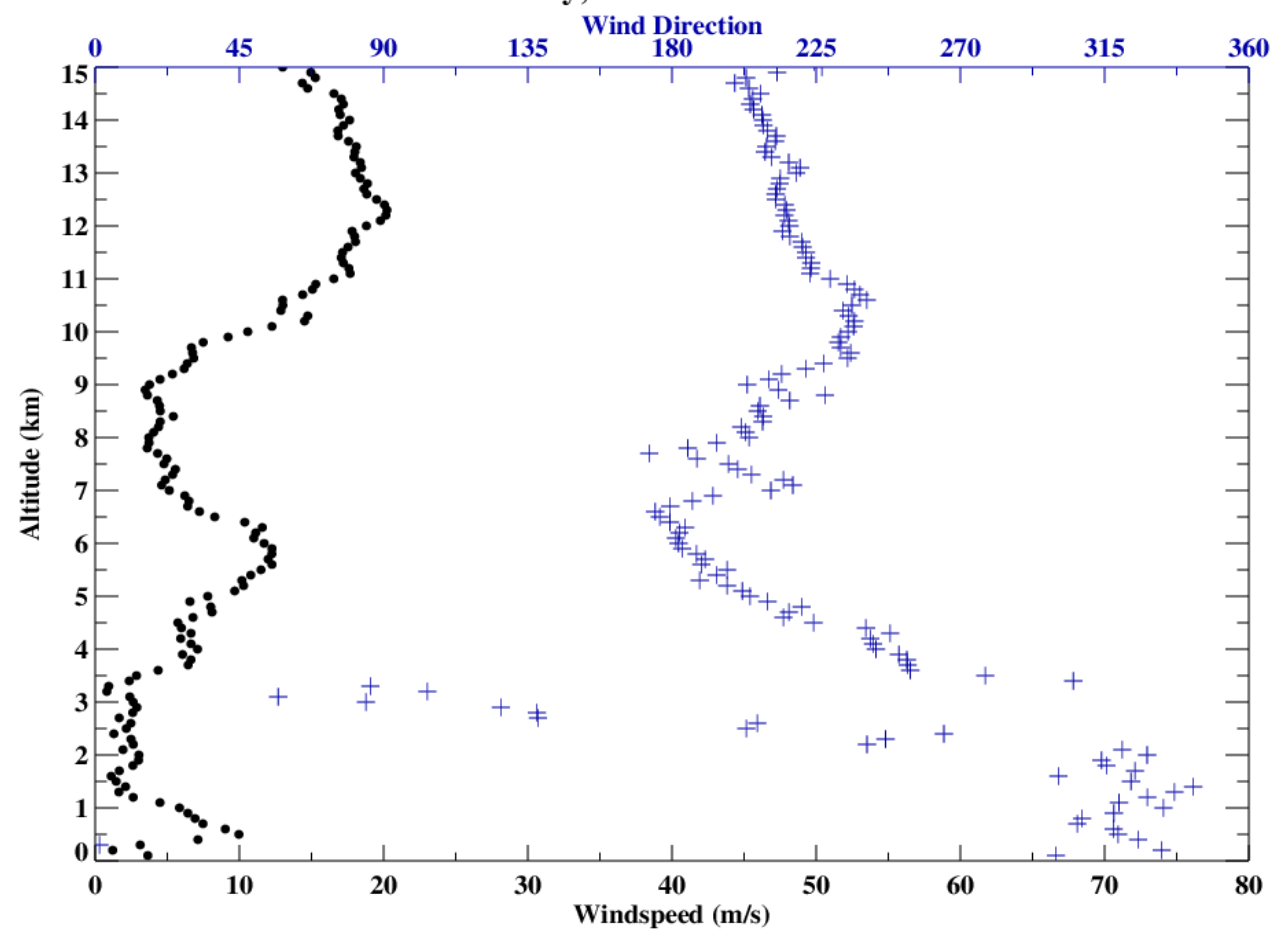



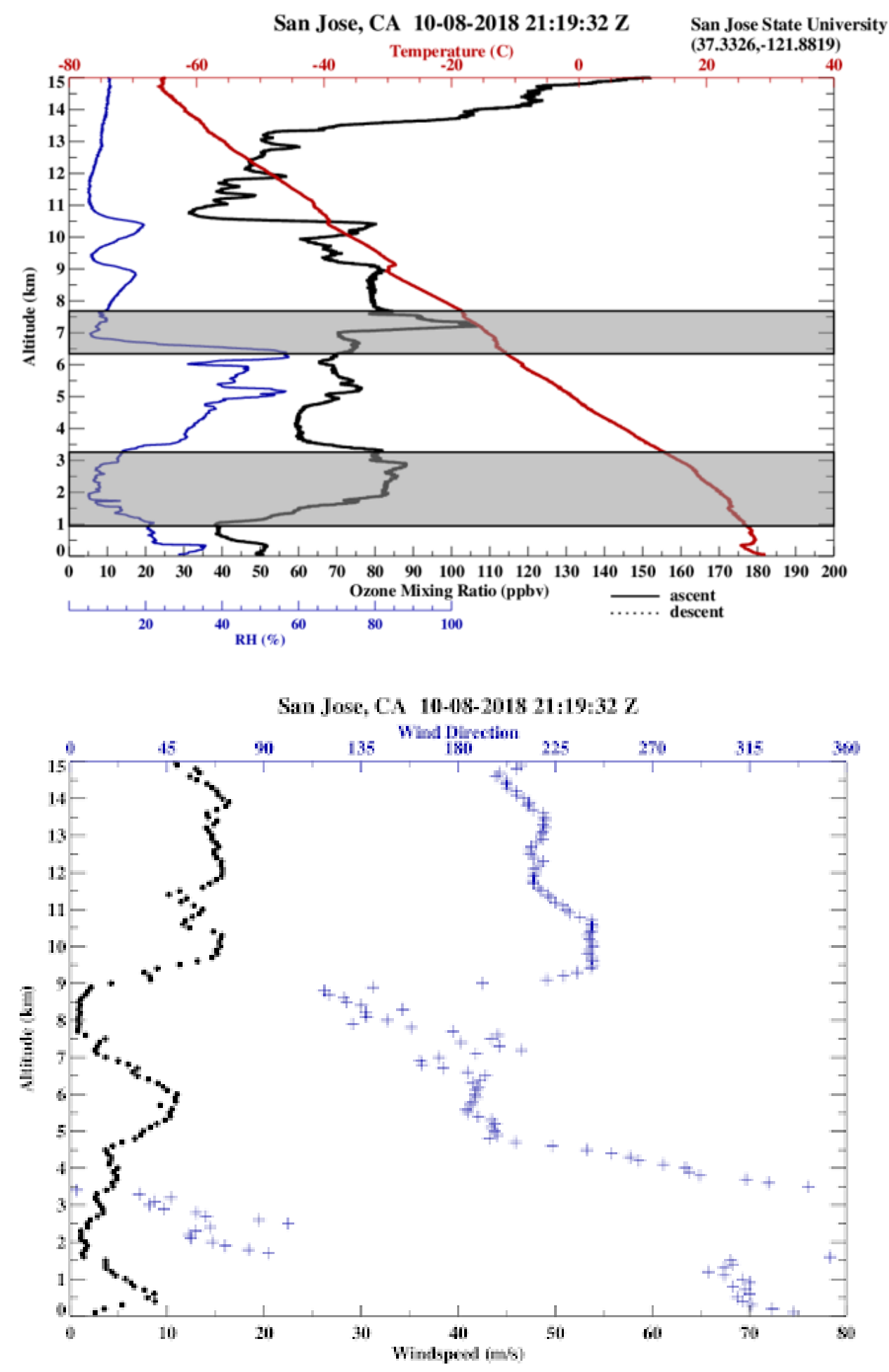

Figure 15. August 10 profiles from HMB (top) and SJ (bottom). Gray sections denote potential STE. 


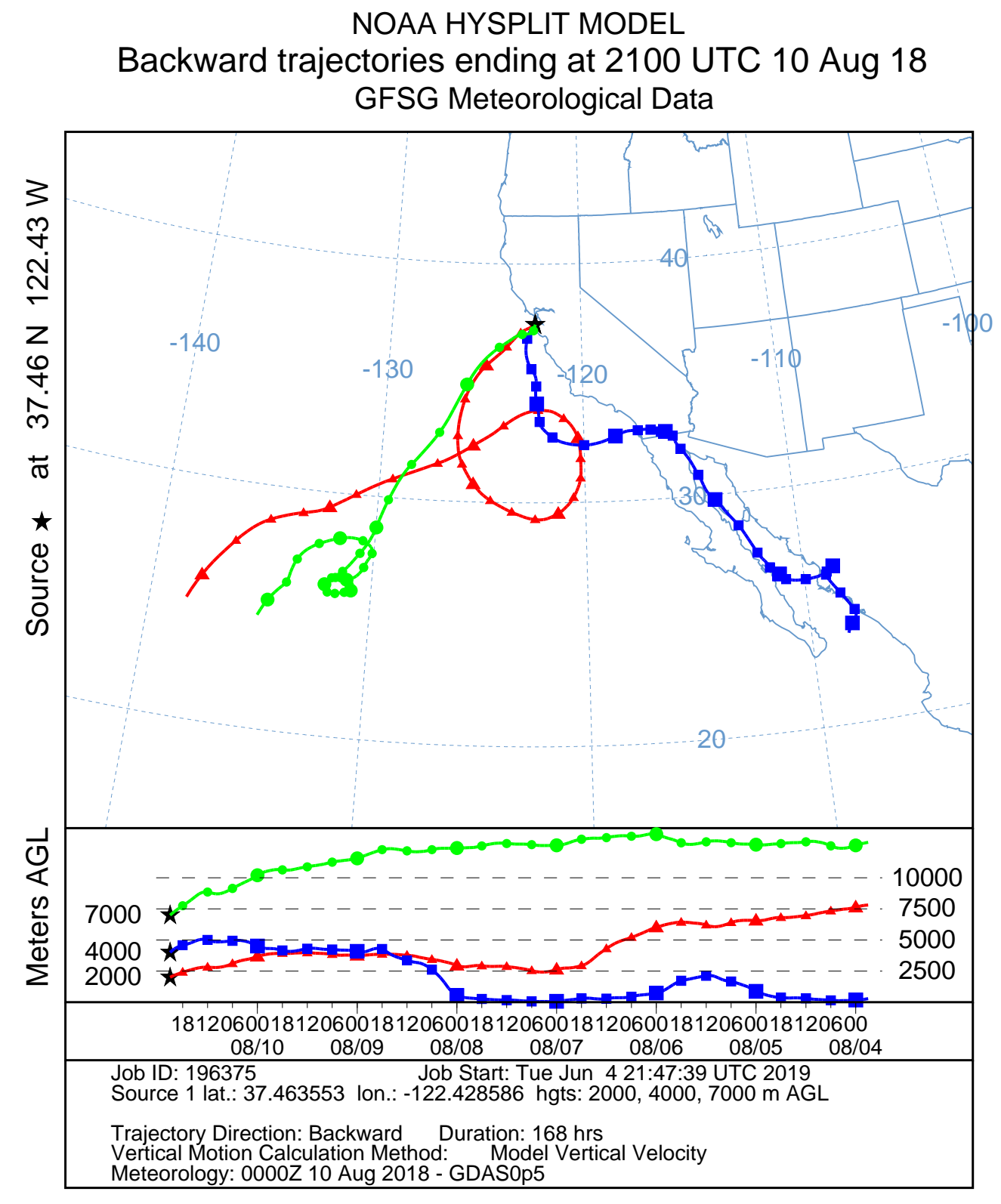


NOAA HYSPLIT MODEL

Backward trajectories ending at 2100 UTC 10 Aug 18

GFSG Meteorological Data

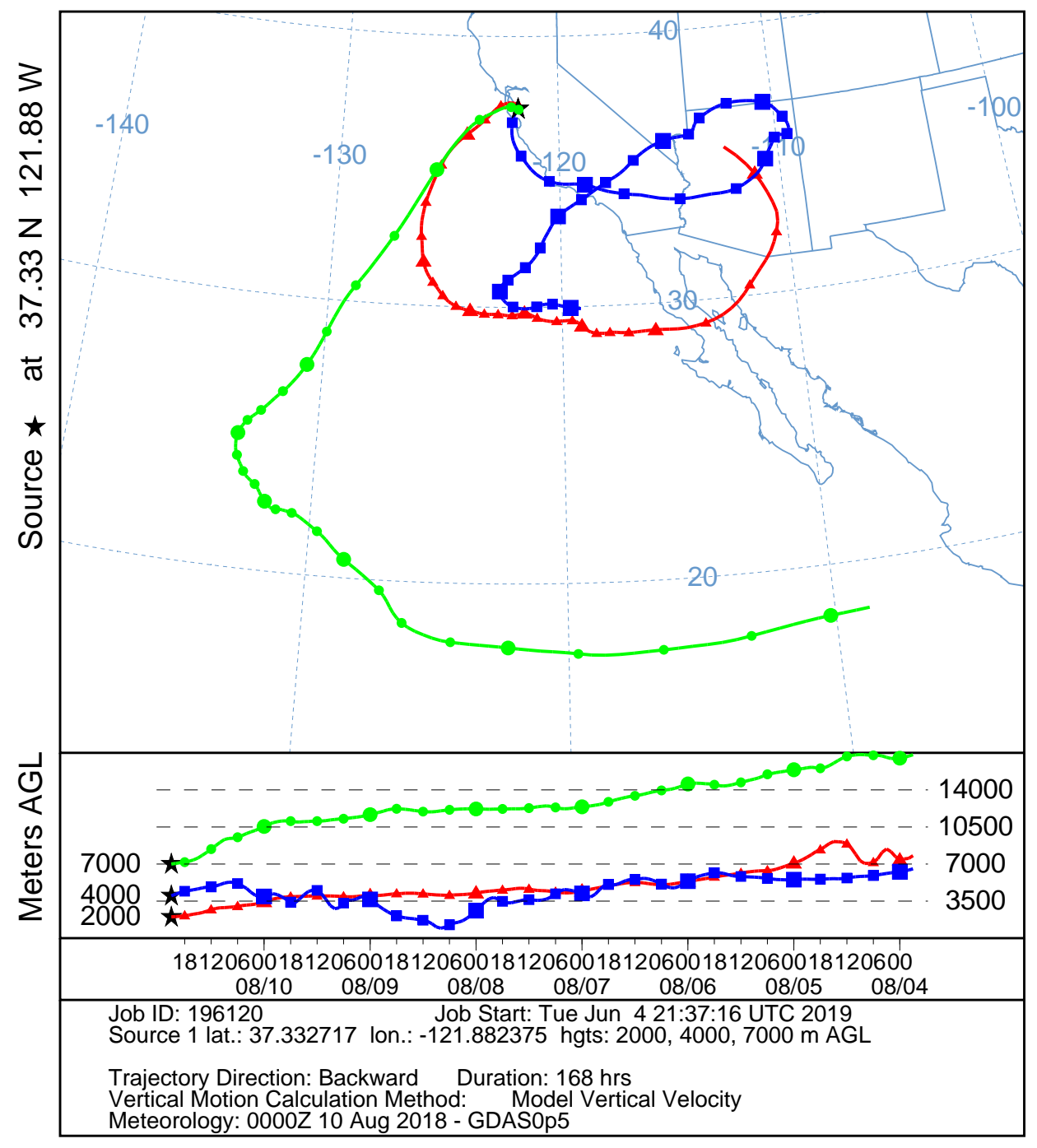

Figure 16. August 10 HYSPLIT back trajectory from HMB (top) and SJ (bottom) at STE altitudes.

The scatterplot of relative humidity and $\mathrm{O}_{3}$ at each location revealed in increase in $\mathrm{O}_{3}$ mixing ratio and decrease in relative humidity at roughly $2 \mathrm{~km}$, indicating stratospheric $\mathrm{O}_{3}$ in the profile (Figure 17). Additionally, high $\mathrm{O}_{3}$ and low relative humidity was present between 6-8 $\mathrm{km}$, corresponding to the $\mathrm{O}_{3}$ peak at $7 \mathrm{~km}$. The RAQMS cross section 
revealed high $\mathrm{O}_{3}$ descending into the region, indicating a STE (Figure 18). As a result, it is concluded that August 10 was impacted by stratospheric air in the profile. This, coupled with residual smoke over the state of California, led to higher $\mathrm{O}_{3}$ concentrations at $\mathrm{SJ}$ throughout the troposphere.
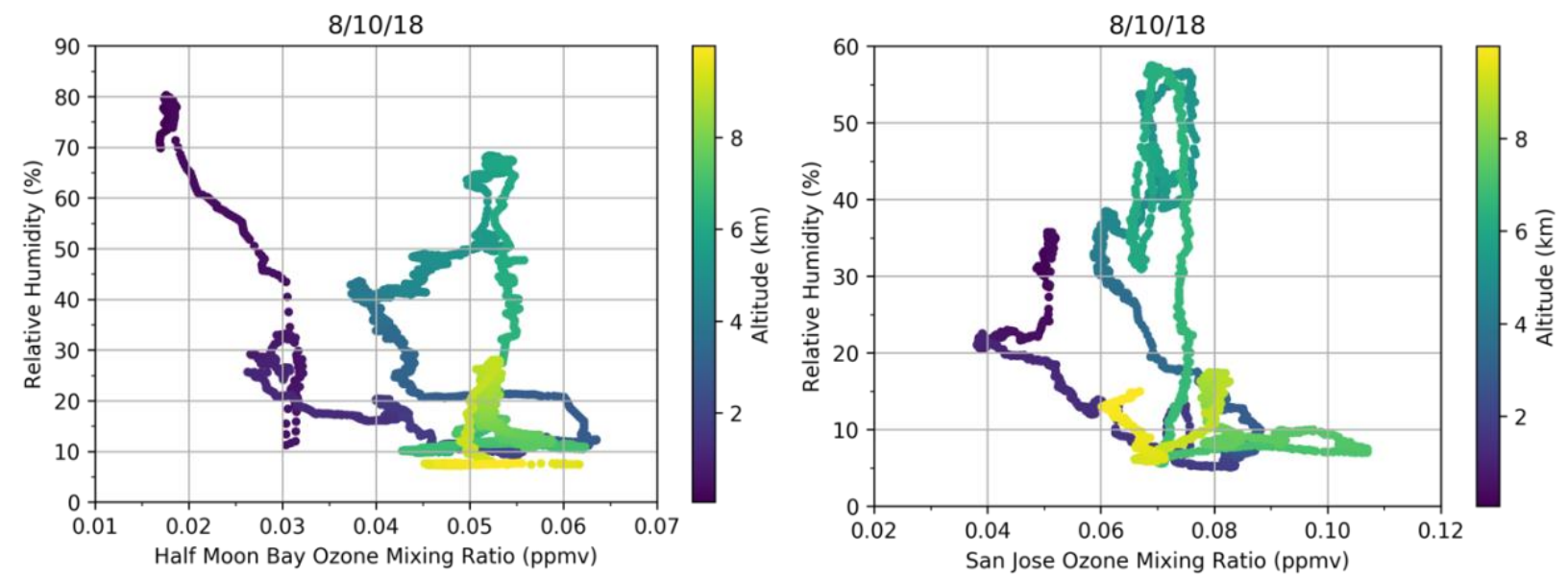

Figure 17. August 10 scatterplots of relative humidity and $\mathrm{O}_{3}$ for $\mathrm{HMB}$ (left) and SJ (right).

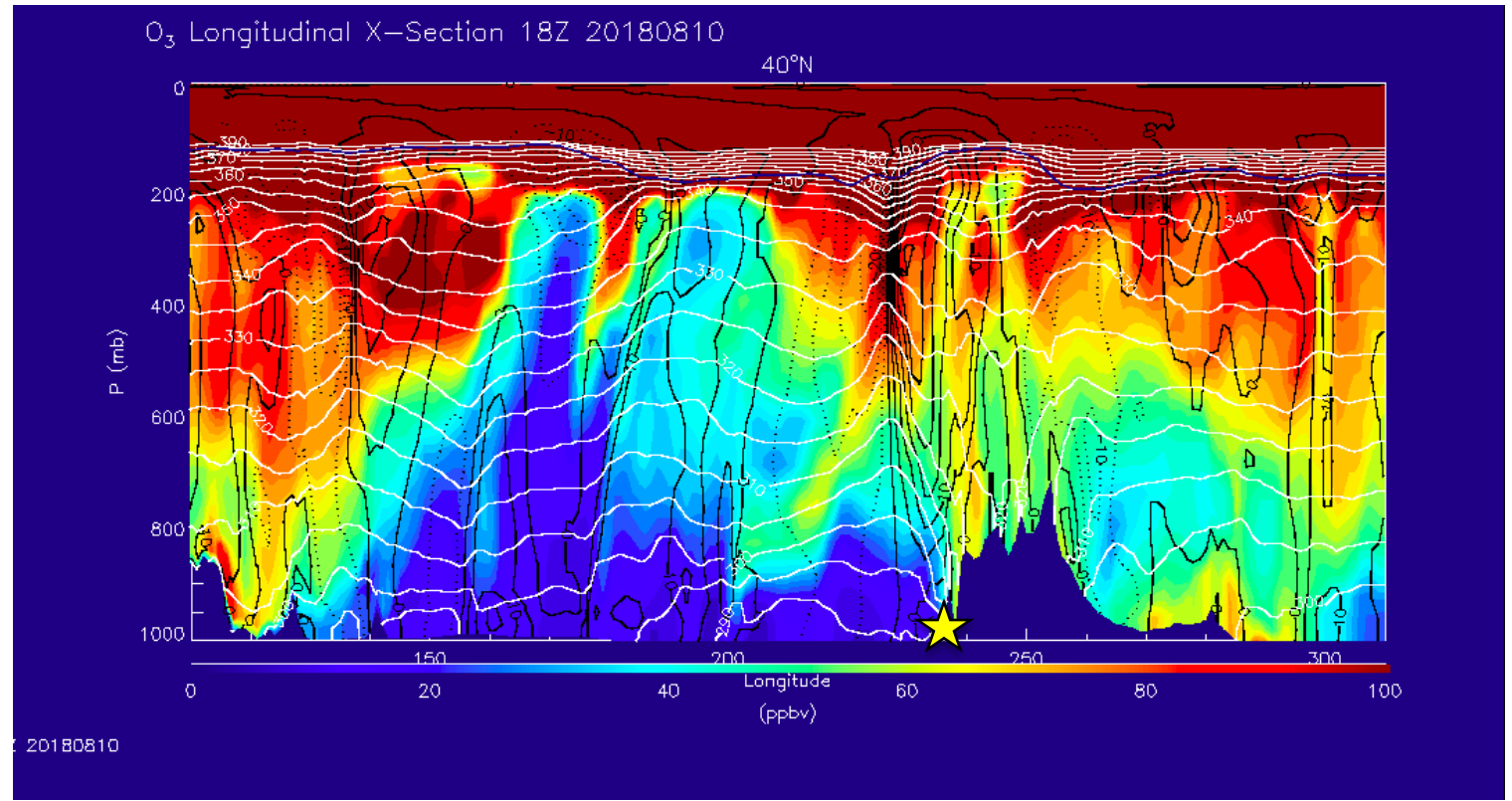

Figure 18. August 10 RAQMS longitudinal cross section of $\mathrm{O}_{3}$ at $40^{\circ} \mathrm{N}$. Location of $\mathrm{SJ}$ is denoted by the yellow star. 


\subsubsection{Statistical results}

Each row in the correlation analysis table consisted of a species, location, hours before launch, and altitude layer. These rows were each mapped to a CC. To avoid presenting a convoluted table, the statistical results were broken up into three sections: hours before launch, averaged layer height, and species. The number of positive significant CCs were summed for each section and presented as a percentage of total significant CCs, both positive and negative. To note, the lowest positive CC for all the data was 0.60. These results are described in Tables 5-7. The majority of significant positive CCs were observed for nitrogen species, with a few also seen for $\mathrm{CO}, \mathrm{SO}_{2}$, $\mathrm{PM}_{2.5}$, and $\mathrm{O}_{3}$. Knox Ave had the majority of significant values, at $57.4 \%$ of the total. Knox Ave $\mathrm{NO}$ and $\mathrm{NO}_{\mathrm{x}}$ constituted about $50 \%$ of the total significant $\mathrm{CCs}$, with the next highest percentage being Jackson Street $\mathrm{NO}$ at 9.8\%. Jackson Street CO, $\mathrm{PM}_{2.5}$, and $\mathrm{O}_{3}$ had no contribution while $\mathrm{NO}_{2}$ and $\mathrm{NO}_{x}$ contributed 1.2 and $2.4 \%$, respectively.

There was no discernable trend between altitude range and strongest relationships (Table 6). Although similar percentages are observed between lower and high-altitude layers (e.g. 1-2 km had 8.5\% and 13-14 $\mathrm{km}$ had 7.3\%), it may not be indicative of the vertical transport processes occurring in this region. Surface emissions are unlikely to reach $11+\mathrm{km}$ in the absence of convective conditions. In summer months in the SJ area, conditions tend to be stable as a result of synoptically high pressure over the region, leading to warm temperatures and few clouds. Additionally, the ML heights were all below $1 \mathrm{~km}$, indicating that surface emissions on these dates were unlikely to reach the upper troposphere as the statistical results imply. This highlights the importance of 
baseline $\mathrm{O}_{3}$ concentrations transporting inland into similar regions with little convective activity; because the surface emissions have limited vertical mixing, baseline $\mathrm{O}_{3}$ concentrations have a dominant influence on the profile aloft, as shown by average enhancements of roughly $\pm 10 \mathrm{ppb}$ above the ML.

In terms of the ideal lag time between surface emission concentrations and peak $\mathrm{O}_{3}$, both 13 and 14 hours before launch had roughly $24 \%$ and $26 \%$ of the significant CCs, respectively (Table 7). These times correspond to midnight and 1 am local time when traffic and urban emissions are reduced. No other lag time had a noticeable pattern, with the next highest being 1 hour before launch at $11 \%$ of the total. However, it is unlikely the surface emissions from 1 hour prior to measurement could lead to $\mathrm{O}_{3}$ production aloft that quickly. 
Table 5. Percentage of significant positive correlation coefficients observed for each species and location.

\begin{tabular}{ccc}
\hline Species & Location & $\begin{array}{c}\text { Percentage of } \\
\text { Total Significant } \\
\text { CCs }\end{array}$ \\
\hline $\mathrm{NO}$ & Jackson Street & $9.8 \%$ \\
$\mathrm{SO}_{2}$ & Jackson Street & $2.4 \%$ \\
$\mathrm{NO}_{x}$ & Jackson Street & $2.4 \%$ \\
$\mathrm{NO}_{2}$ & Jackson Street & $1.2 \%$ \\
$\mathrm{PM}_{2.5}$ & Jackson Street & $0 \%$ \\
$\mathrm{CO}$ & Jackson Street & $0 \%$ \\
$\mathrm{O}_{3}$ & Jackson Street & $0 \%$ \\
\hline $\mathrm{NO}$ & Knox Ave & $30.5 \%$ \\
$\mathrm{NO}_{x}$ & Knox Ave & $19.5 \%$ \\
$\mathrm{PM}_{2.5}$ & Knox Ave & $3.7 \%$ \\
$\mathrm{NO}_{2}$ & Knox Ave & $3.7 \%$ \\
\hline
\end{tabular}


Table 6. Percentage of significant positive correlation coefficients observed for each averaged enhancement profile layer.

\begin{tabular}{|c|c|}
\hline Averaged Layer & $\begin{array}{c}\text { Percentage of Total } \\
\text { Significant CCs }\end{array}$ \\
\hline $0-1 \mathrm{~km}$ & $7.3 \%$ \\
\hline $1-2 \mathrm{~km}$ & $8.5 \%$ \\
\hline $2-3 \mathrm{~km}$ & $3.7 \%$ \\
\hline $3-4 \mathrm{~km}$ & $2.4 \%$ \\
\hline $4-5 \mathrm{~km}$ & $2.4 \%$ \\
\hline $5-6 \mathrm{~km}$ & $2.4 \%$ \\
\hline $6-7 \mathrm{~km}$ & $4.9 \%$ \\
\hline $7-8 \mathrm{~km}$ & $6.1 \%$ \\
\hline $8-9 \mathrm{~km}$ & $6.1 \%$ \\
\hline $9-10 \mathrm{~km}$ & $4.9 \%$ \\
\hline $10-11 \mathrm{~km}$ & $3.7 \%$ \\
\hline $11-12 \mathrm{~km}$ & $3.7 \%$ \\
\hline $12-13 \mathrm{~km}$ & $3.7 \%$ \\
\hline $13-14 \mathrm{~km}$ & $7.3 \%$ \\
\hline $14-15 \mathrm{~km}$ & $6.1 \%$ \\
\hline
\end{tabular}


Table 7. Percentage of significant positive correlation coefficients observed for each hour before launch.

\begin{tabular}{cc}
\hline Time Before Launch & $\begin{array}{c}\text { Percentage of Total } \\
\text { Significant CCs }\end{array}$ \\
\hline 1 hour & $11.0 \%$ \\
2 hours & $3.7 \%$ \\
4 hours & $0 \%$ \\
5 hours & $1.2 \%$ \\
6 hours & $0.0 \%$ \\
7 hours & $3.7 \%$ \\
8 hours & $0 \%$ \\
9 hours & $0 \%$ \\
10 hours & $1.2 \%$ \\
11 hours & $0 \%$ \\
12 hours & $1.2 \%$ \\
13 hours & $1.2 \%$ \\
14 hours & $24.4 \%$ \\
\hline
\end{tabular}

\subsubsection{Mixing layer heights}

The ML heights for each date were below $1 \mathrm{~km}$, with 9 dates below $0.5 \mathrm{~km}$ (Figure 19). The WRF planetary boundary layer heights agreed well with the radiosonde estimations, with the largest difference of $260 \mathrm{~m}$ on July 20 . The WRF model typically under-estimated the radiosonde observations ( 8 out of the 11 dates produced too low mixing layer tops). However, WRF followed the general trend of observed PBL heights 
with correlation values of $\mathrm{r}=0.72$ (p-value $=0.01)$. Overall, both WRF and the radiosonde estimates observed a shallow mixing layer. These low heights reduce the extent of entrainment of tropospheric air into the boundary layer (Wigder et al. 2013), thereby reducing the vertical mixing potential of surface emissions. 

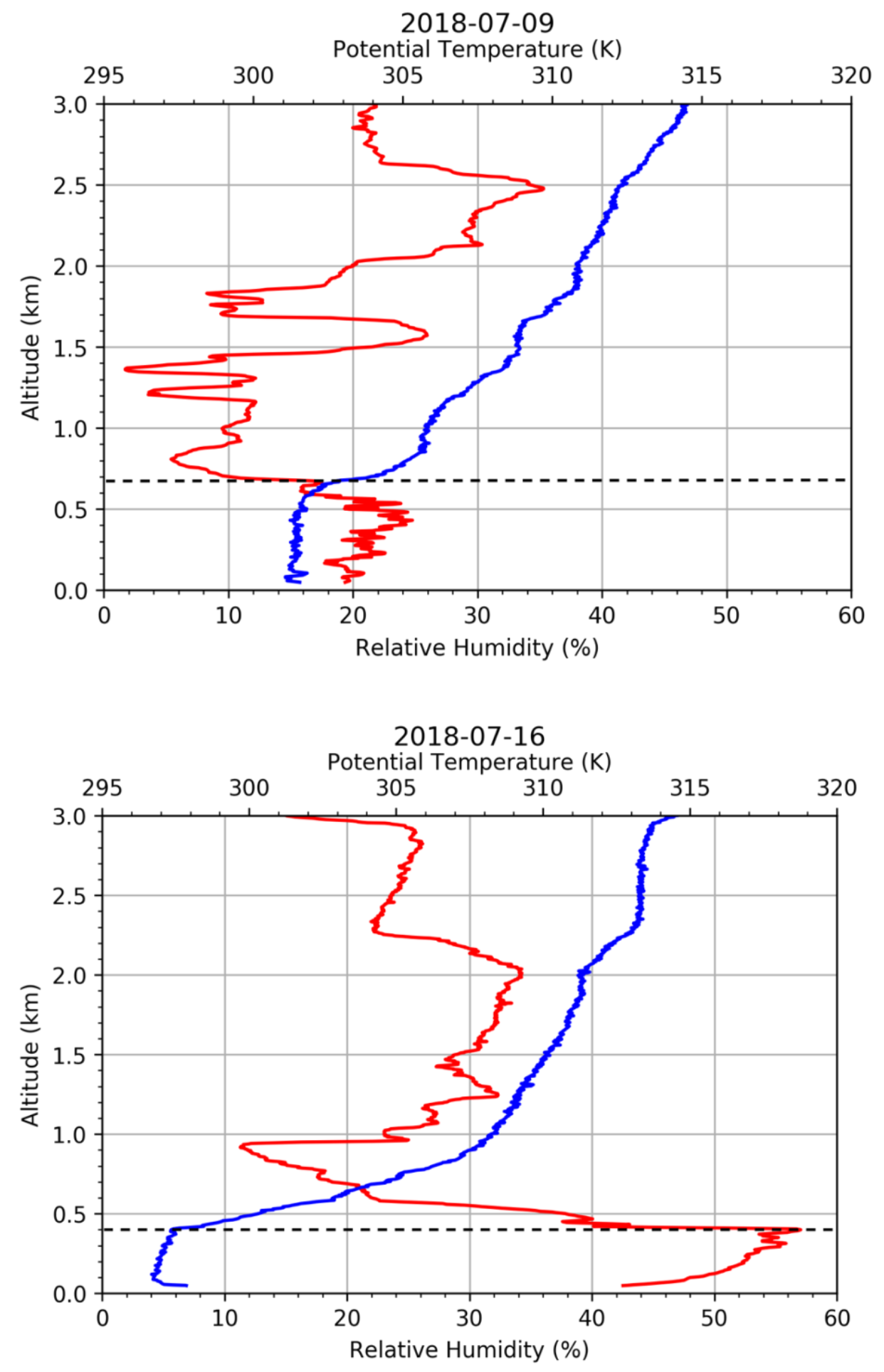

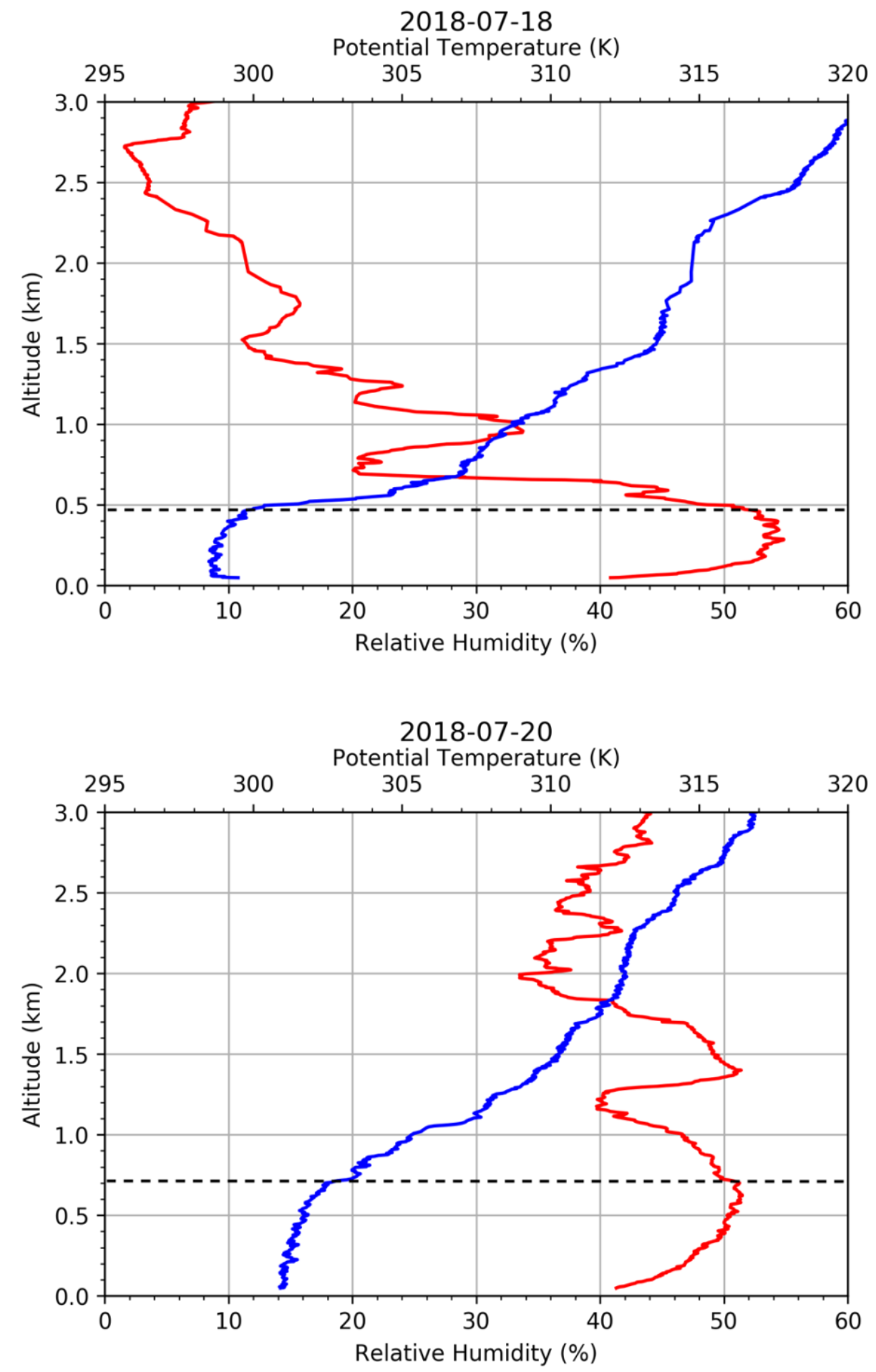

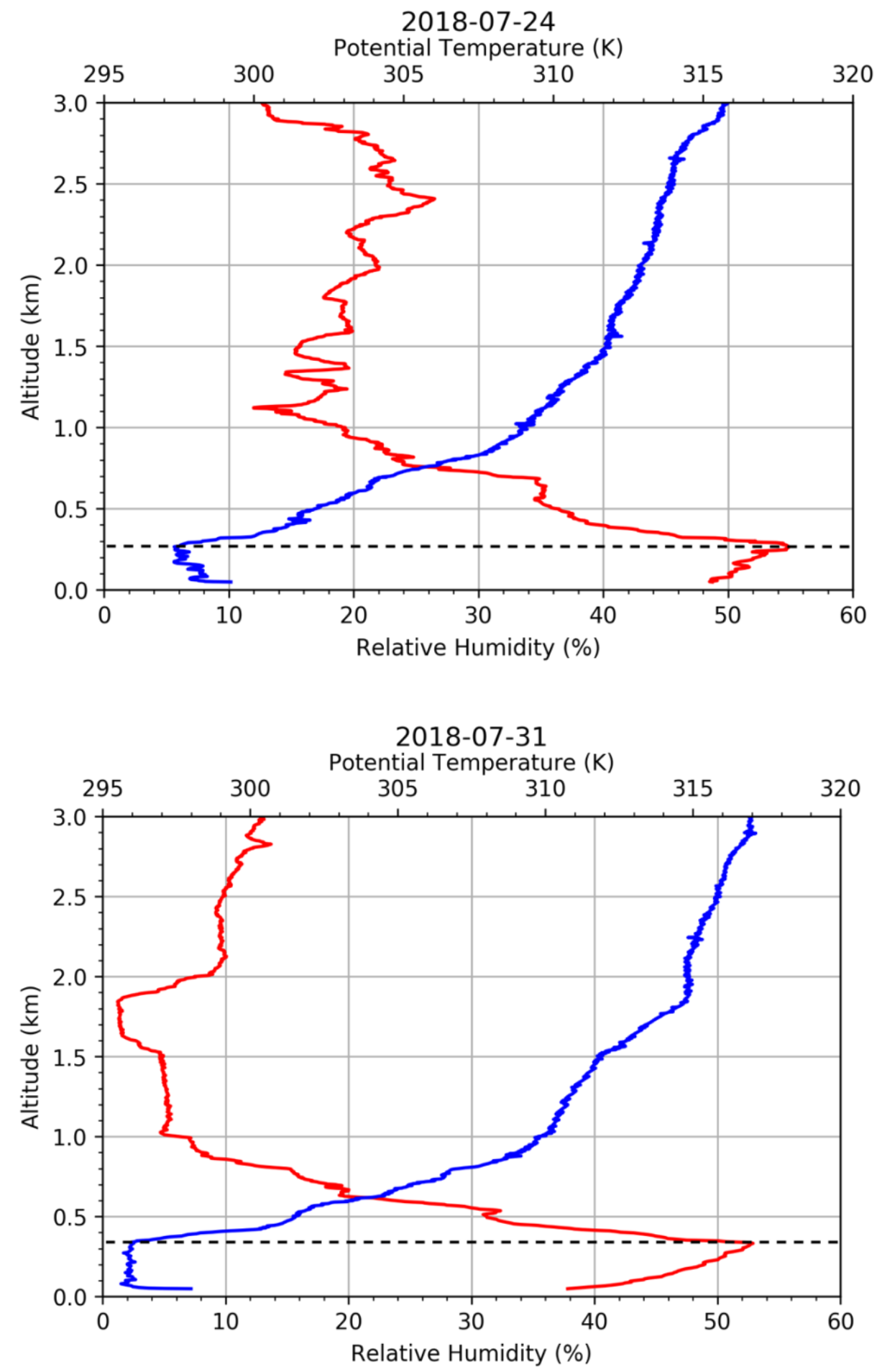

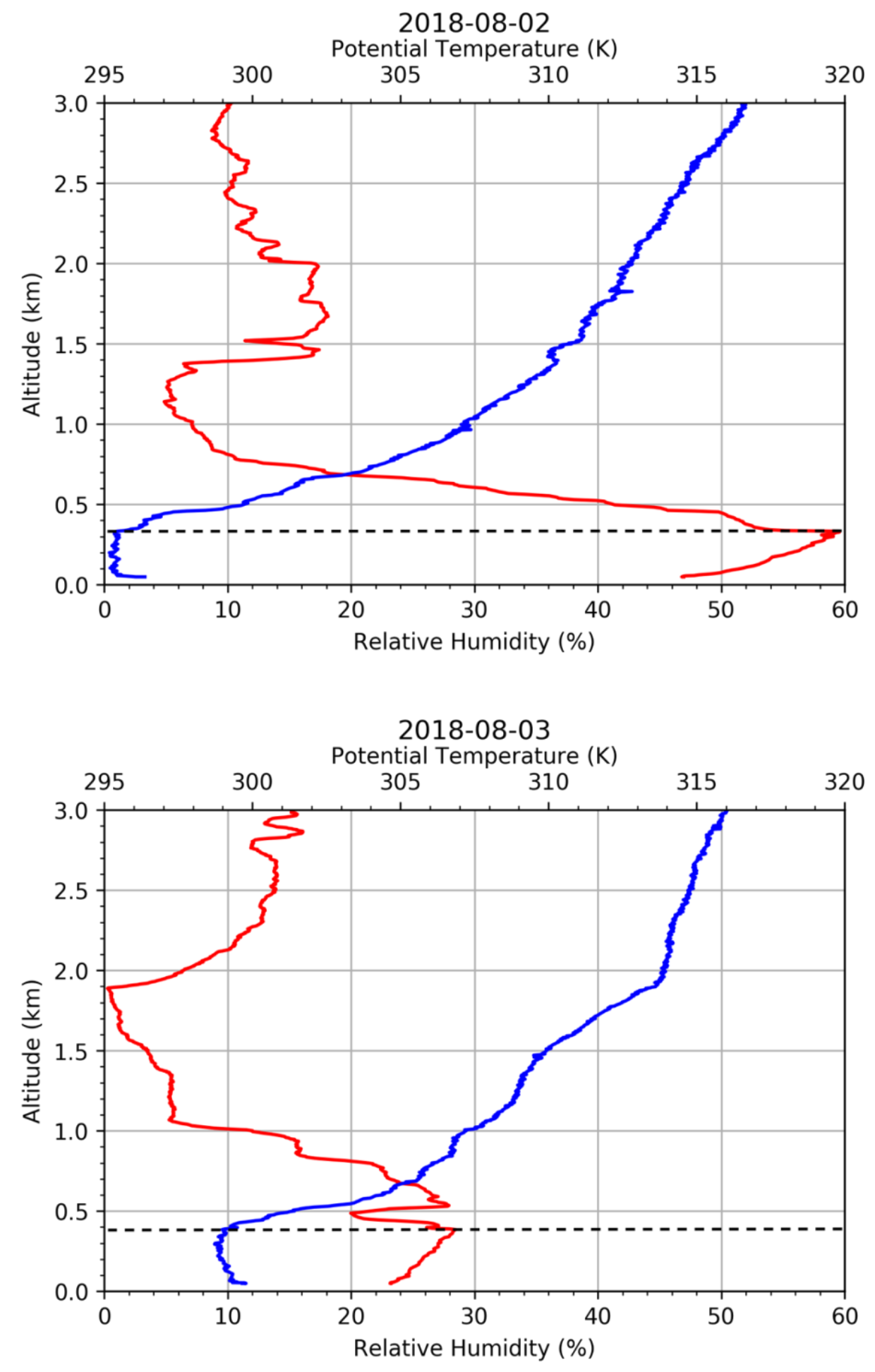

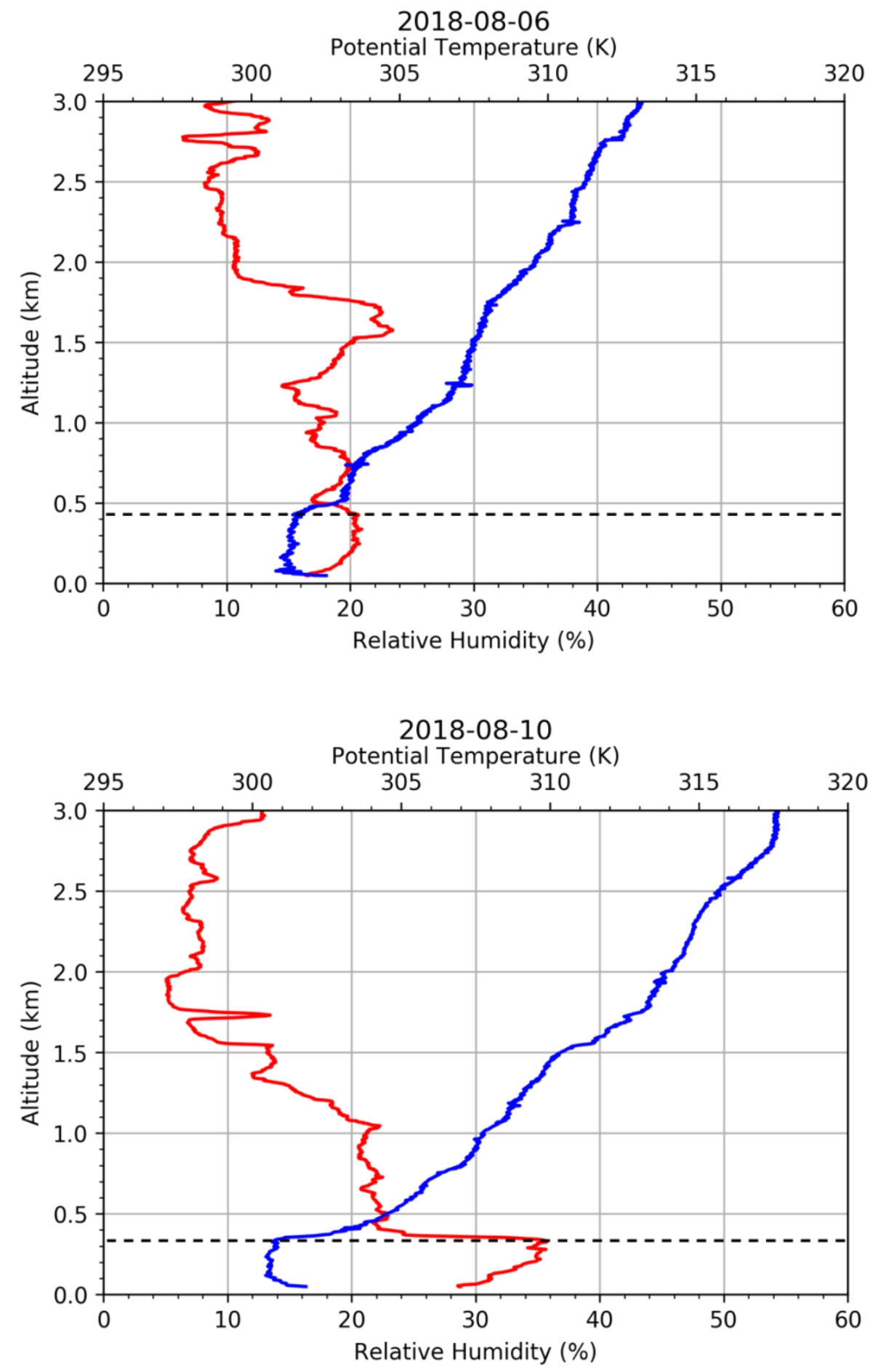


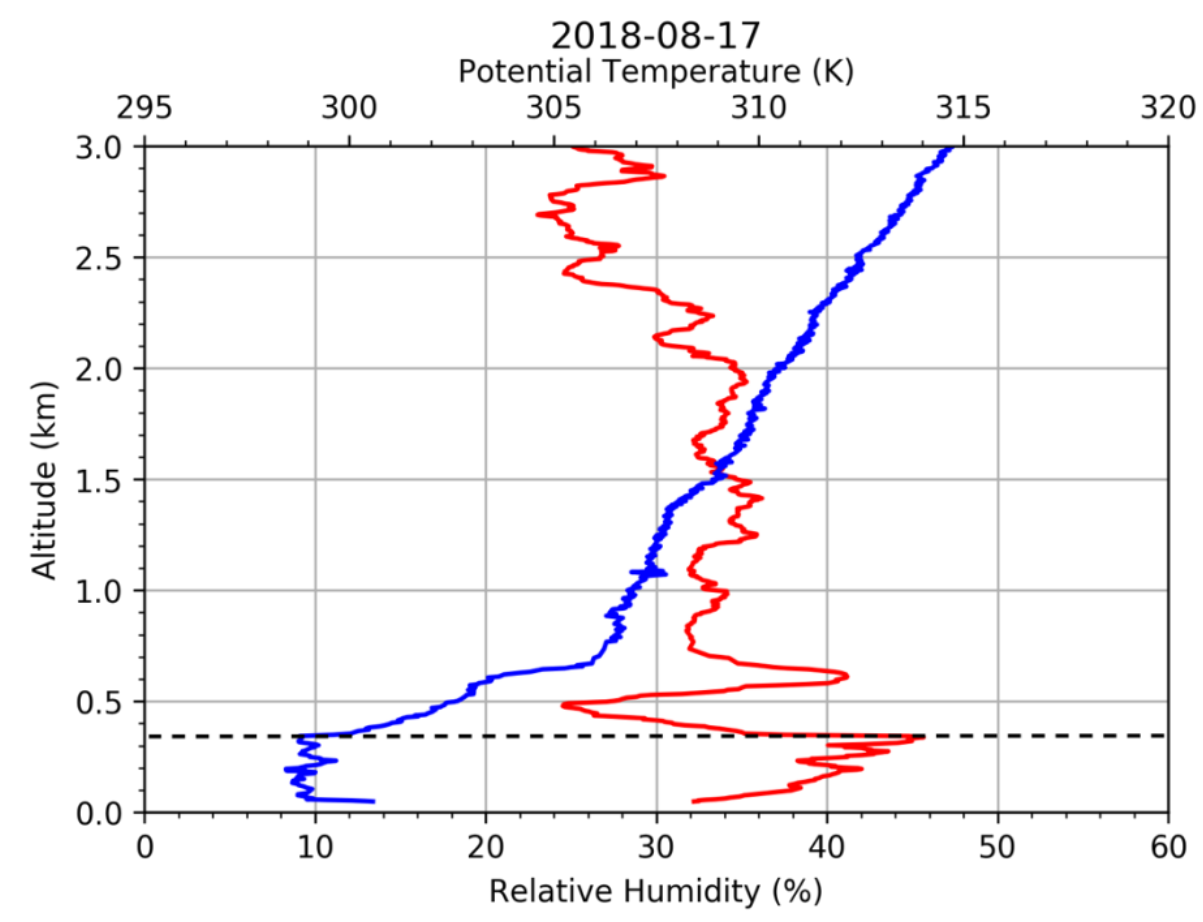

\section{- SJ Relative Humidity (\%) — SJ Potential Temperature (K)}

Figure 19. Mixing layer height $(\mathrm{m})$ estimations for $\mathrm{SJ}$ using the radiosonde observations of relative humidity (\%) and potential temperature $(\mathrm{K})$. At SJ, launches began at roughly $50 \mathrm{~m}$ above ground level. Mixing layer height is denoted by the black dashed line.

\subsubsection{HYSPLIT}

The HYSPLIT back trajectories initiated at $5 \mathrm{~km}$ and $10 \mathrm{~km}$ above ground level suggested airmasses over SJ were typically transported from the SSW to NW, while the surface trajectories were mostly from NNW, passing over the San Francisco Bay region into the SJ area (Figure 20). On dates when the upper-level trajectories did not pass over the HMB region, they typically passed the coastline 50 to $100 \mathrm{~km}$ south of HMB, which is well within synoptic and mesoscale boundaries; therefore the airmass composition is 
likely similar between HMB and the coastal intersection point. Wind directions have minimal differences between HMB and the coast to the south so both sites are primarily receiving onshore winds off of the Pacific. There are few urban areas within this coastal region, so it is a reasonable assumption that $\mathrm{SJ}$ is receiving baseline $\mathrm{O}_{3}$ of similar composition to HMB. Additionally, Parrish et al. 2010 (and Liu et al. 2009 therein) demonstrated that direct transport between Trinidad Head, CA and inland surface sites in the Northern Sacramento Valley is not necessary to explain observed results because the horizontal scale before correlation coefficients decrease by a factor of $e$ is between 500$1000 \mathrm{~km}$. As a result, the HMB concentrations are deemed applicable for the purposes of this study. 
NOAA HYSPLIT MODEL

Backward trajectories ending at 2100 UTC 09 Jul 18

GFSG Meteorological Data

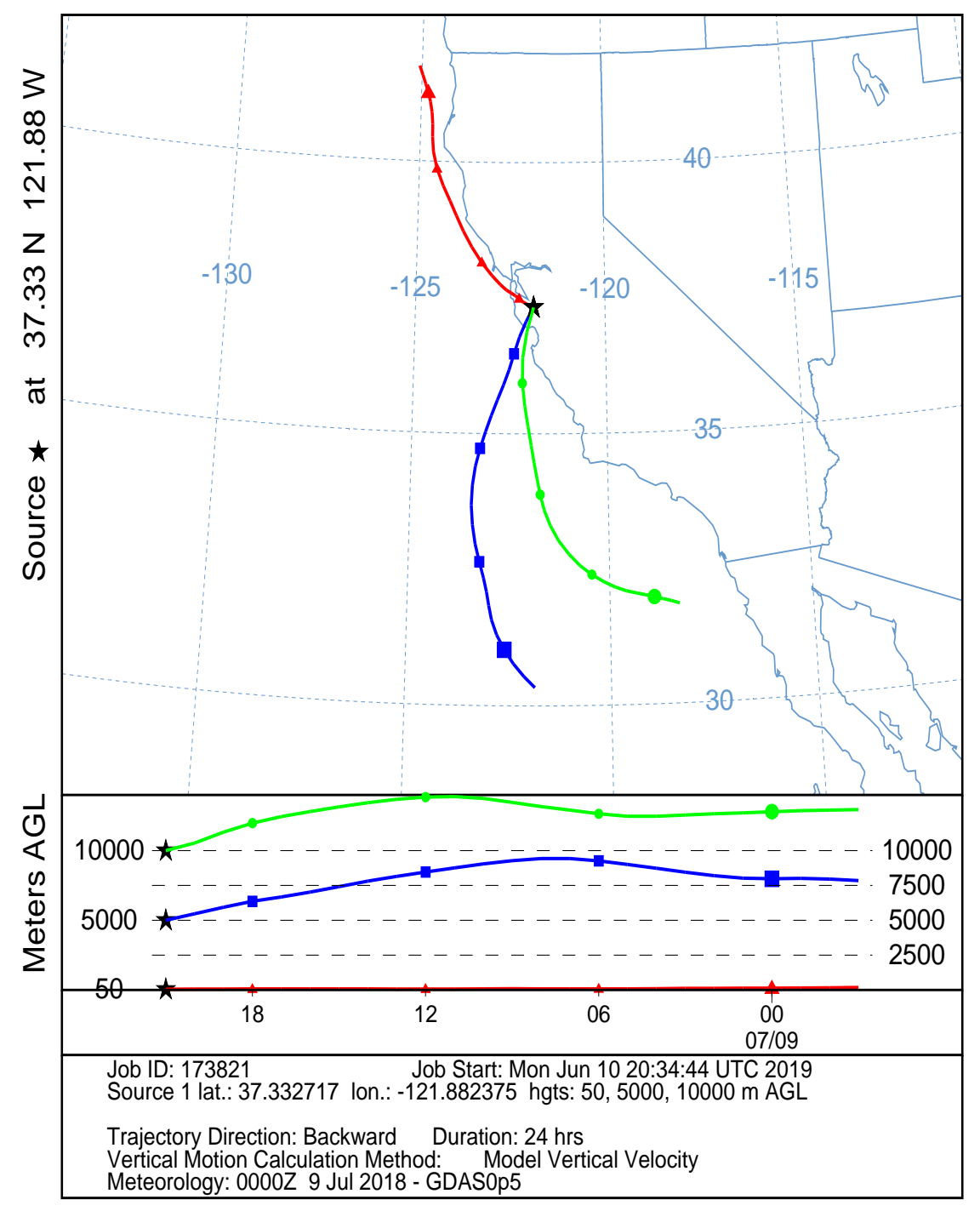

Figure 20. NOAA HYSPLIT backwards trajectory from SJ (Duncan Hall) for July 9. Similar trajectories were present for the other dates, so July 9 is shown to illustrate the overall flow pattern. The red line is $0 \mathrm{~km}$, blue line is $5 \mathrm{~km}$, and green line is $10 \mathrm{~km}$.

This claim was also verified by a Pearson correlation analysis between HMB and SJ on each date. Table 8 describes the correlation coefficients between HMB and SJ for all vertical levels. All CCs are above the significance threshold of 0.5 , with the lowest of 
0.68 on August 6. The visual similarities between HMB and SJ profiles and the small values of the enhancement profile above the ML also confirm the strong relationship between the two sites. On August 10, there was smoke present in the region leading to an SJ enhancement from the surface to the tropopause. However, SJ followed the same trend as HMB thereby illustrating the underlying influence of baseline $\mathrm{O}_{3}$. For all dates combined, the $\mathrm{CC}$ was also high at 0.79. A scatterplot of SJ and HMB is shown in Figure 21 with a least squares regression for $\mathrm{HMB}$ and $\mathrm{SJ}$ of $\mathrm{SJ} \_\mathrm{O}_{3}=0.79 * \mathrm{HMB}_{-} \mathrm{O}_{3}+0.02$. This slope demonstrates the majority of $\mathrm{HMB} \mathrm{O}_{3}$ influence on $\mathrm{SJ}$ and indicates that HMB is higher than $\mathrm{SJ}$ on average at higher altitudes. This slope is also impacted by local production of $\mathrm{O}_{3}$, as $\mathrm{SJ}$ near-surface concentrations are higher than $\mathrm{HMB}$. 
Table 8. Correlations between HMB and SJ profiles.

\begin{tabular}{ccc}
\hline Date & Correlation Coefficient & P-Value \\
\hline July 9, 2018 & 0.93 & 0.0 \\
July 16, 2018 & 0.83 & 0.0 \\
July 18, 2018 & 0.88 & 0.0 \\
July 20, 2018 & 0.84 & 0.0 \\
July 24, 2018 & 0.91 & 0.0 \\
July 31, 2018 & 0.72 & 0.0 \\
August 2, 2018 & 0.92 & 0.0 \\
August 3, 2018 & 0.87 & 0.0 \\
August 6, 2018 & 0.85 & 0.0 \\
August 10, 2018 & & 0.0 \\
\hline & & 0.0 \\
\hline
\end{tabular}




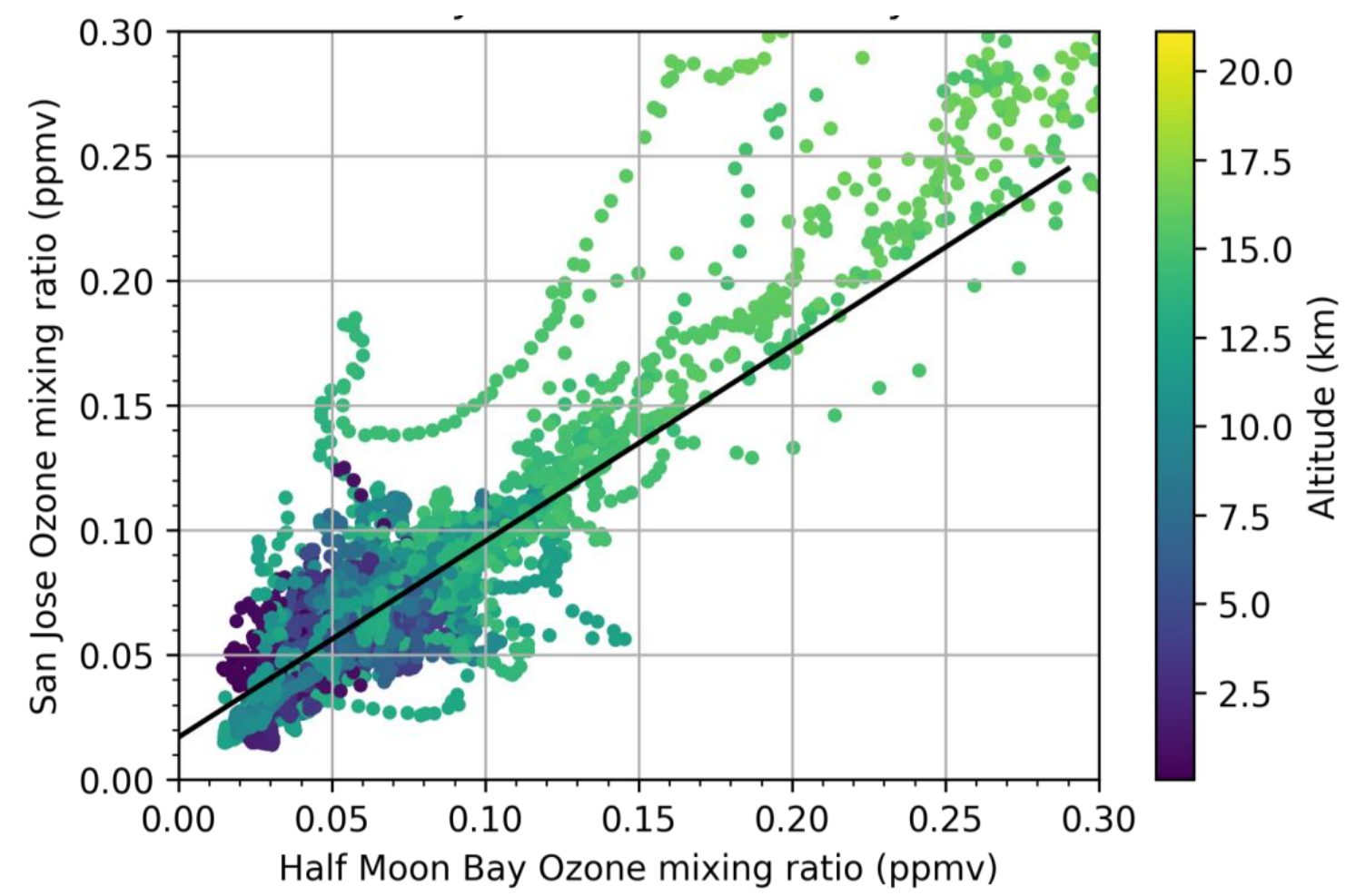

Figure 21. Scatterplot of San Jose $\mathrm{O}_{3}$ mixing ratios (ppmv) and Half Moon $\mathrm{Bay}_{3} \mathrm{O}_{3}$ mixing ratios (ppmv) with a least squares regression line in red $\left(\mathrm{SJ}_{-} \mathrm{O}_{3}=0.79 * \mathrm{HMB}_{-} \mathrm{O}_{3}\right.$ +0.02 ).

\subsubsection{Mixing Layer, Tropospheric, and Total Column $\mathrm{O}_{3}$ Percent Contributions}

The contribution of tropospheric $\mathrm{O}_{3}$ to total column agrees well with the results found in David and Nair 2011 for Trivandrum India, ranging from 11-18\% and 8-15\% respectively (Figure 22). Major differences occur with $\mathrm{ML} \mathrm{O}_{3}$ contribution to tropospheric $\mathrm{O}_{3}$; the present study observed 2-6\% whereas David and Nair 2011 found a near-surface contribution of $34-83 \%$. This difference is likely due to the difference in climate between the two sites; Trivandrum is a tropical climate characterized by high relative humidity and temperatures throughout the year, while SJ experiences comparatively lower temperatures and dry summers. This also leads to less convective activity in $\mathrm{SJ}$, keeping $\mathrm{ML} \mathrm{O}_{3}$ relatively shallow and unmixed, minimizing its 
contribution to tropospheric $\mathrm{O}_{3}$. There does not appear to be a relationship between the percent of $\mathrm{ML} \mathrm{O}_{3}$ contribution on tropospheric $\mathrm{O}_{3}$ and the contribution of tropospheric $\mathrm{O}_{3}$ to total column $\mathrm{O}_{3}$. On July 31, $\mathrm{ML} \mathrm{O}_{3}$ contribution decreased while tropospheric increased and from August 2 to 3, the ML increased to roughly 4.1\% while tropospheric decreased. July 9 had the highest tropospheric contribution, with the next highest on July 31. However, the ML contribution was the lowest on July 31. Therefore, the ML $\mathrm{O}_{3}$ does not appear to be indicative of tropospheric $\mathrm{O}_{3}$ patterns, which supports the earlier findings.

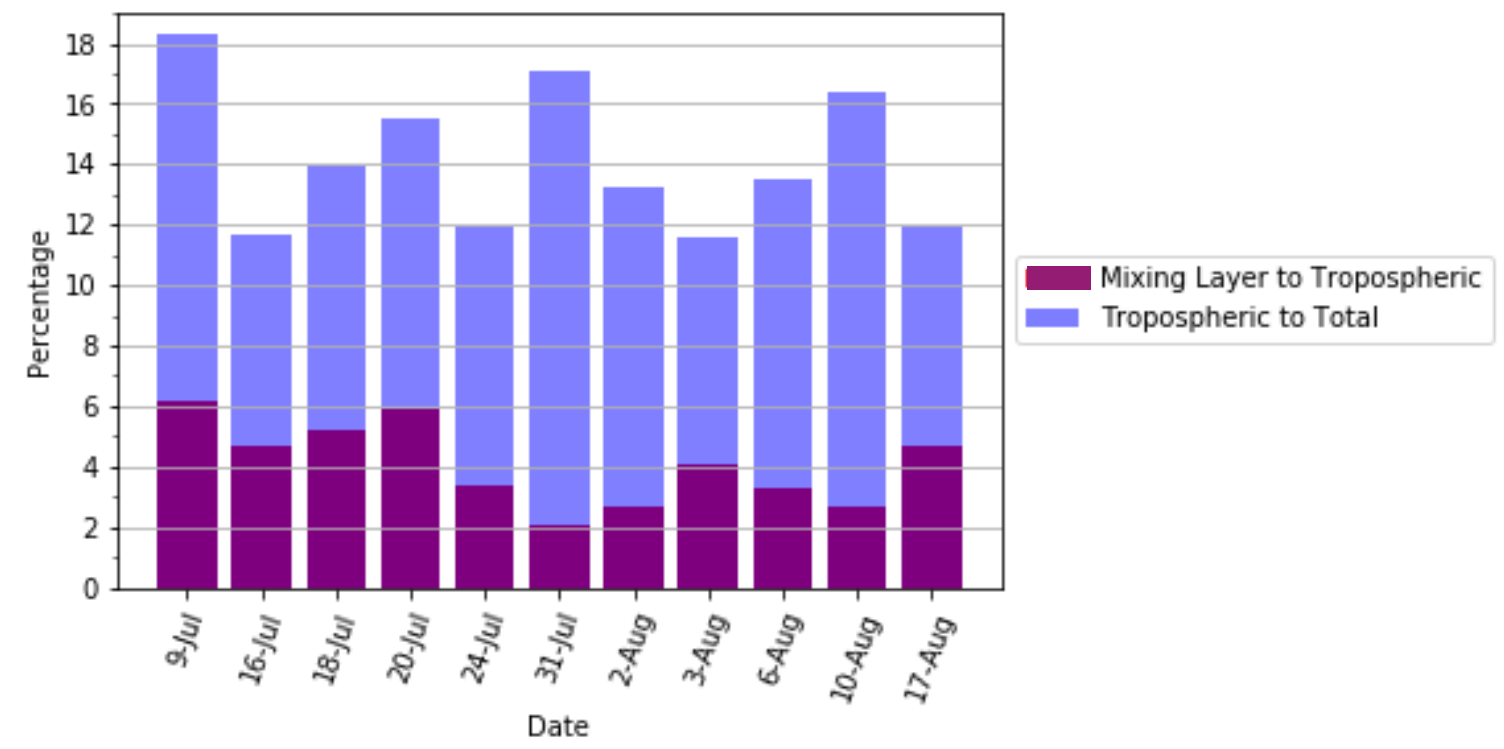

Figure 22. Contribution of ML to tropospheric $\mathrm{O}_{3}$ and tropospheric to total column $\mathrm{O}_{3}$.

\section{Conclusion}

This study constructed a short-term climatology of baseline $\mathrm{O}_{3}$ for $\mathrm{HMB}$ and quantified the impact of locally produced urban emissions on the $\mathrm{O}_{3}$ enhancements aloft and the influence of inland transported baseline $\mathrm{O}_{3}$. The 2016 data were weekly averaged and then compared to the corresponding 2018 profiles by calculating the percent change 
from 2016 to 2018 of total column $\mathrm{O}_{3}$. This demonstrated overall percent decreases in $\mathrm{O}_{3}$, with only one week in July showing an increase. In 2016, El Niño conditions were observed, which results in an extended Pacific jet stream and can increase intercontinental pollution transport. From 2017 into 2018, La Niña conditions were observed, thereby shifting the jet northward. Tropopause pressures did not indicate a higher chance of STEs in 2018 and this was confirmed by only 3 of the 112018 launches indicating STEs. There were also stronger eastward winds in 2016 than 2018. Higher monthly average $\mathrm{O}_{3}$ was also present over California in 2016 compared to 2018, which agrees with the ozonesonde analysis.

To further explore how this baseline $\mathrm{O}_{3}$ is impacting inland, urban regions, an enhancement profile was created to describe the enhancement of $\mathrm{O}_{3}$ over $\mathrm{SJ}$ by subtracting out the $\mathrm{HMB}$ baseline $\mathrm{O}_{3}$ profile. This enhancement profile was averaged into $1 \mathrm{~km}$ layers and statistically analyzed via Pearson correlation to hourly averaged surface urban emissions from three sites. There were no discernable trends observed between the enhancement profile and surface concentrations when verified with atmospheric processes. All mixing layer heights were below $1 \mathrm{~km}$, with many below $0.5 \mathrm{~km}$, as determined by the radiosonde and further confirmed with WRF. Furthermore, the ML $\mathrm{O}_{3}$ percent contribution to tropospheric $\mathrm{O}_{3}$ was very low, confirming minimal impacts of $\mathrm{ML}$ $\mathrm{O}_{3}$ on the tropospheric $\mathrm{O}_{3}$ profile.

The processes that control $\mathrm{O}_{3}$ production and transport are fairly large scale, so it is expected that HMB and SJ are strongly related above the ML. All CCs were greater than 0.5 and, with the exception of July 31 and August 10, the tropospheric 
differences between the two profiles remained close to zero. Even on dates with residual smoke from wildfires, the SJ profile closely followed the same trend as HMB, illustrating the underlying influence of baseline $\mathrm{O}_{3}$. The least squares linear regression equation had a slope of 0.79 , indicating a tendency for higher $\mathrm{O}_{3}$ concentrations at $\mathrm{HMB}$ aloft.

The results of this study highlight the importance of understanding baseline $\mathrm{O}_{3}$ transporting inland to the western U.S. Even for central California, which is susceptible to high pollution events due to low mixing layer heights keeping pollutants close to the surface and inhibiting vertical mixing, baseline $\mathrm{O}_{3}$ remains the predominant influence on free and upper tropospheric $\mathrm{O}_{3}$. Consequently, as urban emissions decrease with improved controls, upper level $\mathrm{O}_{3}$ concentrations are still influenced by baseline $\mathrm{O}_{3}$ trends, which presents a unique challenge for remaining within the NAAQS for $\mathrm{O}_{3}$. Additionally, because the statistical analysis was not indicative of the physical processes occurring, it alone is not a sufficient method for examining the impacts of surface emissions on $\mathrm{O}_{3}$ aloft. It would be useful to incorporate modeling studies to further assess vertical transport processes in inland urban regions in the western U.S., as well as investigate the inland transport of baseline $\mathrm{O}_{3}$ from the coast further inland into California to supplement existing literature. 


\section{References}

Anenberg, S. C., Horowitz, L. W., Tong, D. Q., and West, J. J. (2010), An Estimate of the Global Burden of Anthropogenic Ozone and Fine Particulate Matter on Premature Human Mortality Using Atmospheric Modeling. Environmental Health Perspectives, 118, 1189-1195, doi:10.1289/ehp.0901220.

Ao, C., Chan, T., Iijima, B., Li, J., Mannucci, A., Teixeira, J., Tian, B., and Waliser, D. (2008), Planetary boundary layer information from GPS radio occultation measurements, GRAS SAF Workshop on Applications of GPSRO Measurements, 2008. 123-131.

Avnery, S., Mauzerall, D. L., Lui, J., and Horowitz, L. W. (2011), Global crop yield reductions due to surface ozone exposure: 1 . Year 2000 potential crop production losses and economic damage under two scenarios of $\mathrm{O}_{3}$ production. Atmos. Environ., 45, 2284-2296, https://doi.org/10.1016/j.atmosenv.2011.01.002.

Avnery, S., Mauzerall, D. L., Lui, J., and Horowitz, L. W. (2011), Global crop yield reductions due to surface ozone exposure: 2. Year 2030 potential crop production losses and economic damage under two scenarios of $\mathrm{O}_{3}$ production. Atmos. Environ., 45, 2297-2309, https://doi.org/10.1016/j.atmosenv.2011.01.002.

Baylon, P. M., Jaffe, D. A., Pierce, R. B., and Gustin, M. S. (2016), Interannual Variability in Baseline Ozone and Its Relationship to Surface Ozone in the Western U.S. Environ. Sci. Technol., 50, 2994-3001, doi:10.1021/acs.est.6b00219.

Bell, M. L., Peng, R. D., and Dominici, F. (2006), The Exposure-Response Curve for Ozone and Risk of Mortality and the Adequacy of Current Ozone Regulations. Environmental Health Perspectives, 114, 532-536, doi:10.1289/ehp.8816.

Berman, J. D., Fann, N., Hollingsworth, J. W., Pinkerton, K. E., Rom, W. N., Szema, A. M., Breysse, P. N., White, R. H., and Curriero, F. C. (2012), Health Benefits from Large-Scale Ozone Reduction in the United States. Environmental Health Perspectives, 120, 1404-1410, doi:10.1289/ehp.1104851.

Bianco, L., Djalalova, I. V., King, C. W., and Wilczak, J. M. (2011), Diurnal Evolution and Annual Variability of Boundary-Layer Height and Its Correlation to Other 
Meteorological Variables in California's Central Valley. Boundary-Layer Meteorol, 140, 491-511, doi:10.1007/s10546-011-9622-4.

Chin, M., Jacob, D. J., Munger, J. W., Parrish, D. D., Doddridge, B. G. (1994), Relationship of ozone and carbon monoxide over North America. J. Geophys. Res., 99, 14565-14573, https://doi.org/10.1029/94JD00907.

Cold \& Warm Episodes by Season. Climate Prediction Center. Retrieved from https://origin.cpc.ncep.noaa.gov/products/analysis_monitoring/ensostuff/ONI_v5.php.

Cooper, O. R., et al. (2010), Increasing springtime ozone mixing ratios in the free troposphere over western North America. Nature, 463, 344-348, doi:10.1038/nature08708.

Cooper, O. R., et al. (2011), Measurement of western US baseline ozone from the surface to the tropopause and assessment of downwind impact regions. J. Geophys. Res., 116, D00v03, doi: 10.1029/2011JD016095.

Cooper, O. R., Gao, R., Tarasick, D., Leblanc, T., Sweeney, C. (2012), Long-term ozone trends at rural ozone monitoring sites across the United States, 1990-2010. J. Geophys. Res., 117, D22307, https://doi.org/10.1029/2012JD018261.

Cooper, O. R., Langford, A. O., Parrish, D. D., and Fahey, D. W. (2015), Challenges of a lowered U.S. ozone standard. Science, 348, 6239, 1096-1097, doi: 10.1126/science.aaa5748.

Croes, B.E., and E.M Fujita (2003), The 1997 Southern California Ozone Study (SCOS97-NARSTO): Introduction and perspective. Atmos. Environ., 37, (Suppl. 2):S3-S26. doi:10.1016/S1352-2310(03)00378-9.

David, L. M. and Nair, P. R. (2011), Diurnal and seasonal variability of surface ozone and $\mathrm{NO}_{\mathrm{x}}$ at a topical coastal site: Association with mesoscale and synoptic meteorological conditions. J. Geophys. Res., 116, doi:10.1029/2010JD015076.

Dentener, F., Stevenson, D., Cofala, J., Mechler, R., Amann, M., Bergamaschi, P., Raes, F., and Derwent, R. (2005), The impact of air pollutant and methane emission controls on tropospheric ozone and radiative forcing: CTM calculations for the period 1990-2030. Atmos. Chem. Phys., 5, 1731-1755, https://doi.org/10.5194/acp-5-17312005. 
Dodman, D. (2011), Forces driving urban greenhouse gas emissions. Current Opinion in Environmental Sustainability, 3, 121-125, doi:10.1016/j.cosust.2010.12.013.

Ellingsen, K. et al. (2008), Global ozone and air quality: a multi-model assessment of risks to human health and crops. Atmos. Chem. Phys. Discuss, 8, 2163-2223, https://doi.org/10.5194/acpd-8-2163-2008.

Environmental Protection Agency (2015), National Ambient Air Quality Standards for Ozone. Federal Register, 80, 65292-65468, available at https://www.gpo.gov/fdsys/pkg/FR-2015-10-26/pdf/2015-26594.pdf.

Finlayson-Pitts, B. J. and Pitts Jr., J. N. (1993), Atmospheric Chemistry of Tropospheric Ozone Formation: Scientific and Regulatory Implications. Air and Waste Management Association, 43, 1091-1100, https://doi.org/10.1080/1073161X.1993.10467187.

Fiore, A. M., Jacob, D. J., Field, B. D., Streets, D. G., Fernandes, S. D., and Jang, C. (2002), Linking ozone pollution and climate change: The case for controlling methane. Geophysical Research Letters, 29, 25-1-25-4, doi:10.1029/2002GL015601.

Fiore, A. M., West, J. J., Horowitz, L. W., Naik, V., and Schwarzkopf, M. D. (2008), Characterizing the tropospheric ozone response to methane emission controls and the benefits to climate and air quality. J. Geophys. Res., 113, doi:10.1029/2007JD009162.

Fishman, J. and Seiler, W. (1983), Correlative nature of ozone and carbon monoxide in the troposphere: Implications for the tropospheric ozone budget J. Geophys. Res. Oceans, 88, 3662-3670, https://doi.org/10.1029/JC088iC06p03662.

Garrat, J. R. (1994), Review: the atmospheric boundary layer. Earth-Science Reviews, 37, 89-134.

Gilge, S., Plass-Duelmer, C., Fricke, W., Kaiser, A., Ries, L., Buchmann, B., and Steinbacher, M. (2010), Ozone, carbon monoxide and nitrogen oxides time series at four apline GAW mountain stations in central Europe. Atmos. Chem. Phys., 10, 12295-12316, doi:10.5194/acp-10-12295-2010. 
Global Modeling and Assimilation Office (GMAO), MERRA-2 inst1_2d_asm_Nx:2d, 1Hourly, Instantaneous, Single-Level, Assimilation, Single-Level Diagnostics V5. 12.4, Greenbelt, MD, USA, Goddard Earth Sciences Data and Information Services Center (GES DISC), Accessed: 10.5067/3Z173KIE2TPD.

Goldstein, A. H., Millet, D. B., McKay, M., Jaeglé, L., Horowitz, L., Cooper, O., Hudman, R., Jacob, D., J., Oltmans, S., and Clarke, A. (2004), Impact of Asian emissions on observations at Trinidad Head, California, during ITCT 2K2. J. Geophys. Res., 109, D23S17, doi:10.1029/2003JD004406.

Gorai, A. K., Tuluri, F., Tchounwou, P. B., and Ambinakudige, S. (2015), Influence of local meteorology and $\mathrm{NO}_{2}$ conditions on ground-level ozone concentrations in the eastern part of Texas, USA. Air Qual. Atmos. Health, 8, 81-96, doi:10.1007/s11869014-0276-5.

Grewe, V., Dahlmann, K., Matthes, S., and Steinbrecht, W. (2012), Attributing ozone to $\mathrm{NO}_{\mathrm{x}}$ emissions: Implications for climate mitigation measures. Atmos. Environ., 59, 102-107, doi:10.1016/j.atmosenv.2012.05.002.

Hudman et al. (2004), Ozone production in transpacific Asian pollution plumes and implications for ozone air quality in California. J. Geophys. Res., 109, doi:10.1029/2004JD004974.

Jaffe, D., Price, H. U., Parrish, D. D., Goldstein, A., and Harris, J. (2003), Increasing background ozone during spring on the west coast of North America. Geophysical Research Letters, 30, doi:10.1029/2003GL017024.

Jaffe, D. and Ray, J. (2007), Increase in surface ozone at rural sites in the western US. Atmos. Environ., 41, 5452-5463, https://doi.org/10.1016/j.atmosenv.2007.02.034.

Jaffe, D. A., Cooper, O. R., Fiore, A. M., Henderson, B. H., Tonnesen, G. S., Russell, A. G., Henze, D. K., Langford, A. O., Lin, M., and Moore, T. (2018), Scientific assessment of background ozone over the U.S.: Implications for air quality management. Elem. Sci. Anth., 6, https://doi.org/10.1525/elementa.309.

Jenkin, M. E. and Clemitshaw, K. C. (2000), Ozone and other secondary photochemical pollutants: chemical processes governing their formation in the planetary boundary 
layer. Atmos. Environ., 34, 2499-2527, https://doi.org/10.1016/S13522310(99)00478-1.

John, J. C. St., Chameides, W. L., and Saylor, R. (1998), Role of anthropogenic $\mathrm{NO}_{\mathrm{x}}$ and VOC as ozone precursors: A case study from the SOS Nashville/Middle Tennessee Ozone Study. J. Geophys. Res., 103, 22,415-22,423, https://doi.org/10.1029/98JD00973.

Johnson, B. J., Oltmans, S. J., Vomel, H., Smit, H. G. J., Deshler, T., and Kroger, C. (2002), Electrochemical concentration cell (ECC) ozonesonde pump efficiency measurements and tests on the sensitivity to ozone of buffered and unbuffered ECC sensor cathode solutions. J. Geophys. Res., 107, doi:10.1029/2001JD000557.

Langford, A. O., Senff, C. J., Alvarez II, R. J., Brioude, J., Cooper, O. R., Holloway, J. S., Lin, M. Y., Marchbanks, R. D., Pierce, R. B., Sandberg, S. P., Weickmann, A. M., and Williams, E. J. (2015), An overview of the 2013 Las Vegas Ozone Study (LVOS): Impact of stratospheric intrusions and long-range transport on surface air quality. Atmos. Environ., 109, 305-322, https://doi.org/10/1016/j.atmosenv.2014.08.040.

Langford, A. O., Alvarez II, R. J., Brioude, J., Fine, R., Gustin, M. S., Lin, M. Y., Marchbanks, R. D., Pierce, R. B., Sandberg, S. P., Senff, C. J., Weickmann, A. M., Williams, E. J. (2017), Entrainment of stratospheric air and Asian pollution by the convective boundary layer in the southwestern U.S. J. Geophys. Res., 122, https://doi.org/10.1002/2016JD025987.

Langford A. O., Alvarez II, R. J., Brioude J., Evan, S., Iraci, L. T., Kirgis, G., Kuang, S., Leblanc, T., Newchurch, M. J., Pierce, R. B., Senff, C. J., and Yates, E. L. (2018), Coordinated profiling of stratospheric intrusions and transported pollution by the Tropospheric Ozone Lidar Network (TOLNet) and NASA Alpha Jet experiment (AJAX): Observations and comparison to HYSPLIT, RAQMS, and FLEXPART. Atmos. Environ., 174, 1-14, https://doi.org/10.1016/j.atmosenv.2017.11.031.

Langford, A. O. et al. (2019), Intercomparison of lidar, aircraft, and surface ozone measurements in the San Joaquin Valley during the California Baseline Ozone Transport Study (CABOTS). Atmos. Meas. Tech., 12, 1889-1904, https://doi.org/10.5194/amt-12-1889-2019. 
Lefohn, A. S., Shadwick, D., Oltmans, S. J. (2010), Characterizing changes in surface ozone levels in metropolitan and rural areas in the United States for 1980-2008 and 1994-2008. Atmos. Environ., 44, (39), 5199-5210.

Lin, M., Fiore, A. M., Cooper, O. R., Horowitz, L. W., Langford, A. O., Levy II, H., Johnson, B. J., Naik, V., Oltmans, S. J., and Senff, C. J. (2012), Springtime high surface ozone events over the western United States: Quantifying the role of stratospheric intrusions. J. Geophys. Res., 117, https://doi.org/10.1029/2012JD018151.

Lin, M., Fiore, A. M., Horowitz, L. W., Langford, A. O., Oltmans, S. J., Tarasick, D., and Rieder, H. E. (2015), Climate variability modulates western US ozone air quality in spring via deep stratospheric intrusions. Nature Communications, $\mathbf{6}$, doi:10.1038/ncomms8105.

Lin, M., Horowitz, L. W., Cooper, O. R., Tarasick, D., Conley, S., Iraci, L. T., Johnson, B., Leblanc, T., Petropavlovskikh, I., and Yates, E. L. (2015), Revisiting the evidence of increasing springtime ozone mixing ratios in the free troposphere over western North America. Geophysical Research Letters, 42, 8719-8728, https://doi.org/10.1002/2015GL065311.

Lin, M., Horowitz, L. W., Payton, R., Fiore, A. M., and Tonnesen, G. (2017), US surface ozone trends and extremes from 1980 to 2014: quantifying the roles of rising Asian emissions, domestic controls, wildfires, and climate. Atmos. Chem. Phys., 17, 29432970, doi:10.5194/acp-17-2943-2017.

Liu, S. and Liang, X. (2010), Observed Diurnal Cycle Climatology of Planetary Boundary Layer Height. Journal of Climate, 23, 5790-5809, DOI: 10.1175/2010JCLI3552.1.

Macdonald, A. M., Anlauf, K. G., Leaitch, W. R., Chan, E., and Tarasick, D. W. (2011), Interannual variability of ozone and carbon monoxide at the Whistler high elevation site: 2002-2006. Atmos. Chem. Phys., 11, 11431-11446, doi:10.5194/acp-11-114312011.

Malone, K., Basso, M., and Nguyen, D. (2013), 2012 Air Monitoring Network Plan, available at 
http://www.baaqmd.gov/ /media/Files/Technical\%20Services/2012_Network_Plan.a shx.

Marcotullio, P. J., Sarzynski, A., Albrecht, J., Schulz, N., and Carcia, J. (2013), The geography of global urban greenhouse gas emissions: an exploratory analysis. Climate Change, 121, 621-634, doi:10.1007/s10584-013-0977-z.

Menut, L., Flamant, C., Pelon, J., and Flamant, P. (1999), Urban Boundary-Layer Height Determination from Lidar MEasurements Over the Paris Area. Applied Optics, 38, 945-954, doi:10.1364/AO.38.000945.

Oltmans, S. J., Lefohn, A. S., Harris, J. M., and Shadwick, D. S. (2008), Background ozone levels of air entering the west coast of the US and assessment of longer-term changes. Atmos. Environ., 42, 6020-6038, doi:10.1016.j.atmosenv.2008.03.034.

Ostro, B. D., Tran, H., and Levy, J. I. (2012), Health Benefits of Reduced Tropospheric Ozone in California. Journal of the Air \& Waste Management Association, 56, 10071021, https://doi.org/10.1080/10473289.2006.10464511.

Parrish, D. D., et al. (2014), Long-term changes in lower tropospheric baseline ozone concentrations: Comparing chemistry-climate models and observations at northern midlatitudes. J. Geophys. Res., 119, 5719-5736, doi:10.1002/2013JDo21435.

Pudasainee, D., Sapkota, B., Shrestha, M. L., Kaga, A., Kondo, A., and Inoue, Y. (2006), Ground level ozone concentrations and its association with NOx and meteorological parameters in Kathmandu valley, Nepal. Atmos. Environ., 40, 8081-8087, doi:10.1016/j. atmosenv.2006.07.011.

Pusede, S. E. and Cohen, R. C. (2012), On the observed response of ozone to $\mathrm{NO}_{\mathrm{x}}$ and VOC reactivity reductions in San Joaquin Valley California 1995-present. Atmos. Chem. Phys., 12, 8323-8339, doi:10.5194/acp-12-8323-2012.

Quan, J., Gao, Y., Zhang, Q., Tie, X., Cao, J., Han, S., Meng, J., Chen, P., and Zhao, D. (2013), Evolution of planetary boundary layer under different weather conditions, and its impact on aerosol concentrations. Particuology, 11, 34-40, https://doi.org/10.1016/j.partic.2012.04.005. 
Rai, R. and Agrawai, M. (2012), Impact of Tropospheric Ozone on Crop Plants. Proc. Natl. Acad. Sci., India, Sect. B Biol. Sci. 82, 241-257, doi:10.1007/s40011-012-00322.

Ryoo, J., Johnson, M. S., Iraci, L. T., Yates, E. L., and Gore, W. (2017), Investigating sources of ozone over California using AJAX airborne measurements and models: Assessing the contribution from long-range transport. Atmos. Environ., 155, 53-67, http://dx.doi.org/10.1016/j.atmosenv.2017.02.008.

Seaman, N. L. and Michelson, S. A. (2000), Mesoscale Meteorological structure of a High-Ozone Episode during the 1995 NARSTO-Northeast Study. Journal of Applied Meteorology, 39, 384-398, https://doi.org/10.1175/15200450(2000)039<0384:MMSOAH>2.0.CO;2.

Seidel, D. J., Ao, C. O., and Li, K. (2010), Estimating climatological planetary boundary layer heights from radiosonde observations: Comparison of methods and uncertainty analysis. J. Geophys. Res., 115, doi:10.1029/2009JD013680.

Seidel, D. J., Zhang, Y., Beljaars, A., Golaz, J., Jacobson, A. R., and Medeiros, B. (2012), Climatology of the planetary boundary layer over the continental United States and Europe. J. Geophys. Res., 117, doi:10.1029/2012JD018143.

Shindell, D. W., Faluvegi, G., Bell, N., and Schmidt, G. A. (2005), An emissions-based view of climate forcing by methane and tropospheric ozone. Geophysical Research Letters, 32, doi:10.1029/2004GL021900.

Simon, H., Reff, A., Wells, B., Xing, J., and Frank, N. (2015), Ozone Trends Across the United States over a Period of Decreasing NOx and VOC Emissions. Eviron. Sci. Technol., 49, 186-195, doi:10.1021/es504514z.

Smith, K. R. et al. (2009), Public health benefits of strategies to reduce greenhouse-gas emissions: health implications of short-lived greenhouse pollutants. The Lancet, 374, 9707, 2035-2038, https://doi.org/10.1016/S0140-6736(09)61716-5.

Stull, R. B. (1988), An introduction to boundary layer meteorology. Kluwer academic publishers. 
Task Force on Hemispheric Transport of Air Pollution (2010), Hemispheric Transport of Air Pollution 2010 Part A: Ozone and Particulate Matter, available at http://pure.iiasa.ac.at/id/eprint/14571/1/HTAP\%202010\%20Part\%20A\%20110407.pd f.

Tu, J., Xia, Z., Wang, H., and Li, W. (2007), Temporal variations in surface ozone and its precursors and meteorological effects at an urban site in China. Atmos. Research, 85, 310-337, doi:10.1016/j.atmosres.2007.02.003.

Turner, M. C. et al. (2016), Long-Term Ozone Exposure and Mortality in a Large Prospective Study. American Journal of Respiratory and Critical Care Medicine, 193, 1134-1142, https://doi.org/10.1164/rccm.201508-1633OC.

U.S. Environmental Protection Agency (1998), National Air Quality and Emissions Trends Report, 1997, available at https://www.epa.gov/sites/production/files/201711/documents/trends_report_1997.pdf.

Wang, X. Y. and Wang, K. C. (2014), Estimation of atmospheric mixing layer height from radiosonde data. Atmos. Meas. Tech., 7, 1701-1709, doi:10.5194/amt-7-17012014.

Wei, W., Cheng, S., Li, G., Wang, G., and Wang, H. (2014), Characteristics of ozone and ozone precursors (VOCs and $\mathrm{NO}_{\mathrm{x}}$ ) around a petroleum refinery in Beijing, China. $J$. Environ. Sci., 26, 332-342, doi:10.1016/S1001-0742(13)60412-X.

West, J. J., Fiore, A. M., Horowitz, L. W., and Mauzerall, D. L. (2006), Global health benefits of mitigating ozone pollution with methane emission controls. PNAS, 103, 3988-3993, https://doi.org/10.1073/pnas.0600201103.

Wigder, N. L., Jaffe, D. A., Herron-Thorpe, F. L., and Vaughan, J. K. (2013), Influence of daily variations in baseline ozone on urban air quality in the United States Pacific Northwest. J. Geophys. Res., 118, 3343-3354, doi:10.1029/2012/JD018738.

Wu, S., Mickley, L. J., Jacob, D. J., Rind, D., and Streets, D. G. (2008), Effects of 20002050 changes in climate and emissions on global tropospheric ozone and the policyrelevant background surface ozone in the United States. J. Geophys. Res., 113, doi:10.1029/2007JD009639. 
Yates, E. L., Iraci, L. T., Roby, M. C., Pierce, R. B., Johnson, M. S., Reddy, P. J., Tadić, J. M., Loewenstein, M., and Gore, W. (2013), Airborne observations and modeling of springtime stratosphere-to-troposphere transport over California. Atmos. Chem. Phys., 13, 12481-12494, doi:10.5194/acp-13-12481-2013.

Zhang, L., Jacob, D. J., Yue, X., Downey, N. V., Wood, D. A., and Blewitt, D. (2014), Sources contributing to background surface ozone in the US Intermountain West. Atmos. Chem. Phys., 14, 5295-5309, doi:10.5194/acp-14-5295-2014.

Ziltinkevich, S. and Baklanov, A. (2001), Calculations of the Height of the Stable Boundary Layer in Practical Applications. Boundary Layer Meteorology, 105, 389409. 